Prepared in cooperation with the U.S. Department of Energy

An Update of Hydrologic Conditions and Distribution of Selected Constituents in Water, Snake River Plain Aquifer and Perched Groundwater Zones, Idaho National Laboratory, Idaho, Emphasis 2006-08

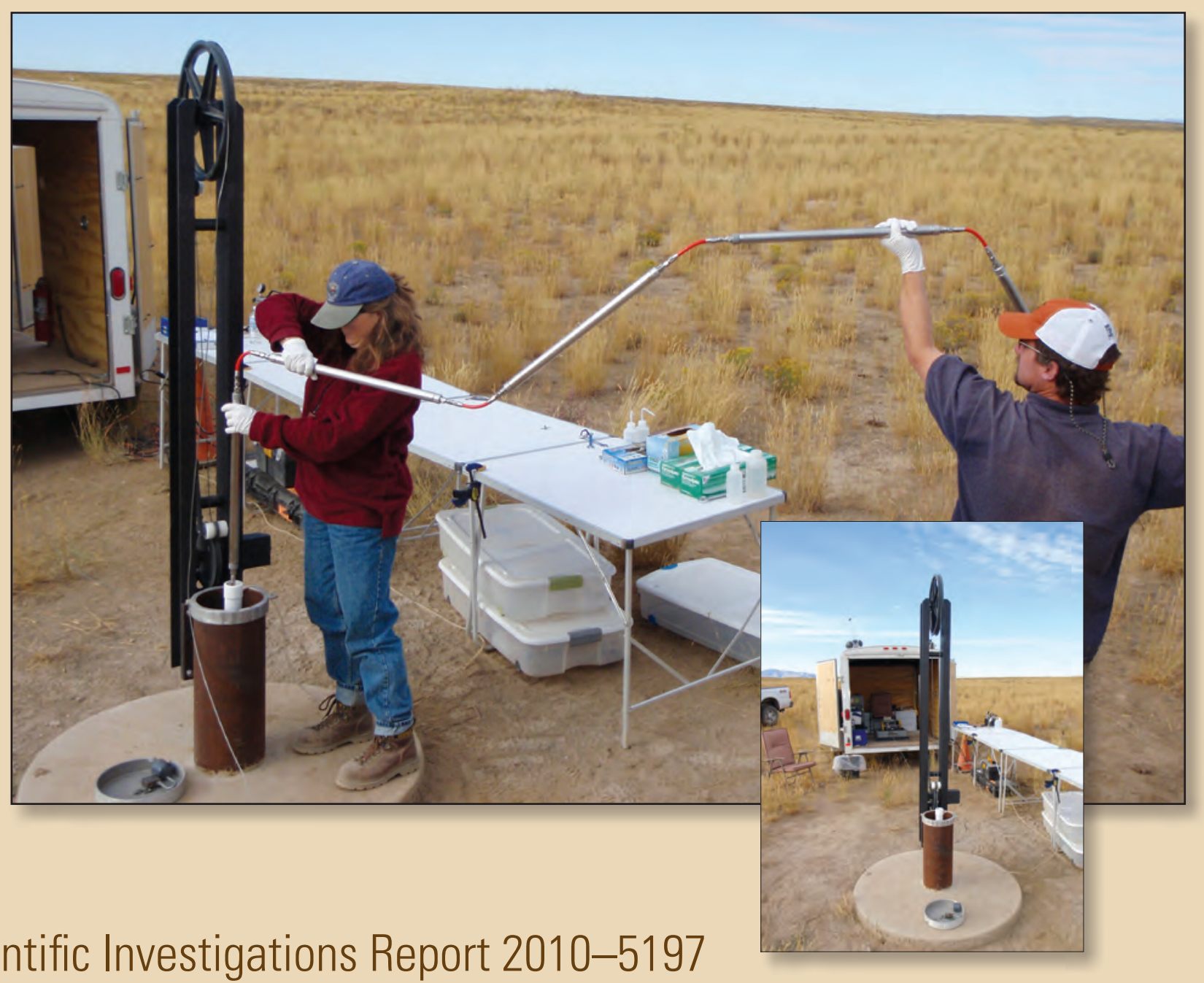

Scientific Investigations Report 2010-5197 
Cover: Photographs of the U.S. Geological Survey multi-level water sampling setup, and U.S. Geological Survey employees deploying water sampling bottles into the well equipped with a Westbay ${ }^{\mathrm{TM}}$ packer sampling system at the Idaho National Laboratory, Idaho. (Photographs courtesy of the U.S. Geological Survey Idaho National Laboratory Project Office, 2008.) 


\section{An Update of Hydrologic Conditions and Distribution of Selected Constituents in Water, Snake River Plain Aquifer and Perched Groundwater Zones, Idaho National Laboratory, Idaho, Emphasis 2006-08}

By Linda C. Davis

Prepared in cooperation with the

U.S. Department of Energy DOE/ID-22212

Scientific Investigations Report 2010-5197 


\section{U.S. Department of the Interior \\ KEN SALAZAR, Secretary}

\section{U.S. Geological Survey \\ Marcia K. McNutt, Director}

U.S. Geological Survey, Reston, Virginia: 2010

For more information on the USGS - the Federal source for science about the Earth, its natural and living resources, natural hazards, and the environment, visit http://www.usgs.gov or call 1-888-ASK-USGS

For an overview of USGS information products, including maps, imagery, and publications, visit http://www.usgs.gov/pubprod

To order this and other USGS information products, visit http://store.usgs.gov

Any use of trade, product, or firm names is for descriptive purposes only and does not imply endorsement by the U.S. Government.

Although this report is in the public domain, permission must be secured from the individual copyright owners to reproduce any copyrighted materials contained within this report.

Suggested citation:

Davis, L.C., 2010, An update of hydrologic conditions and distribution of selected constituents in water, Snake River Plain aquifer and perched groundwater zones, Idaho National Laboratory, Idaho, emphasis 2006-08: U.S. Geological Survey Scientific Investigations Report 2010-5197 (DOE/ID-22212), 80 p. 


\section{Contents}

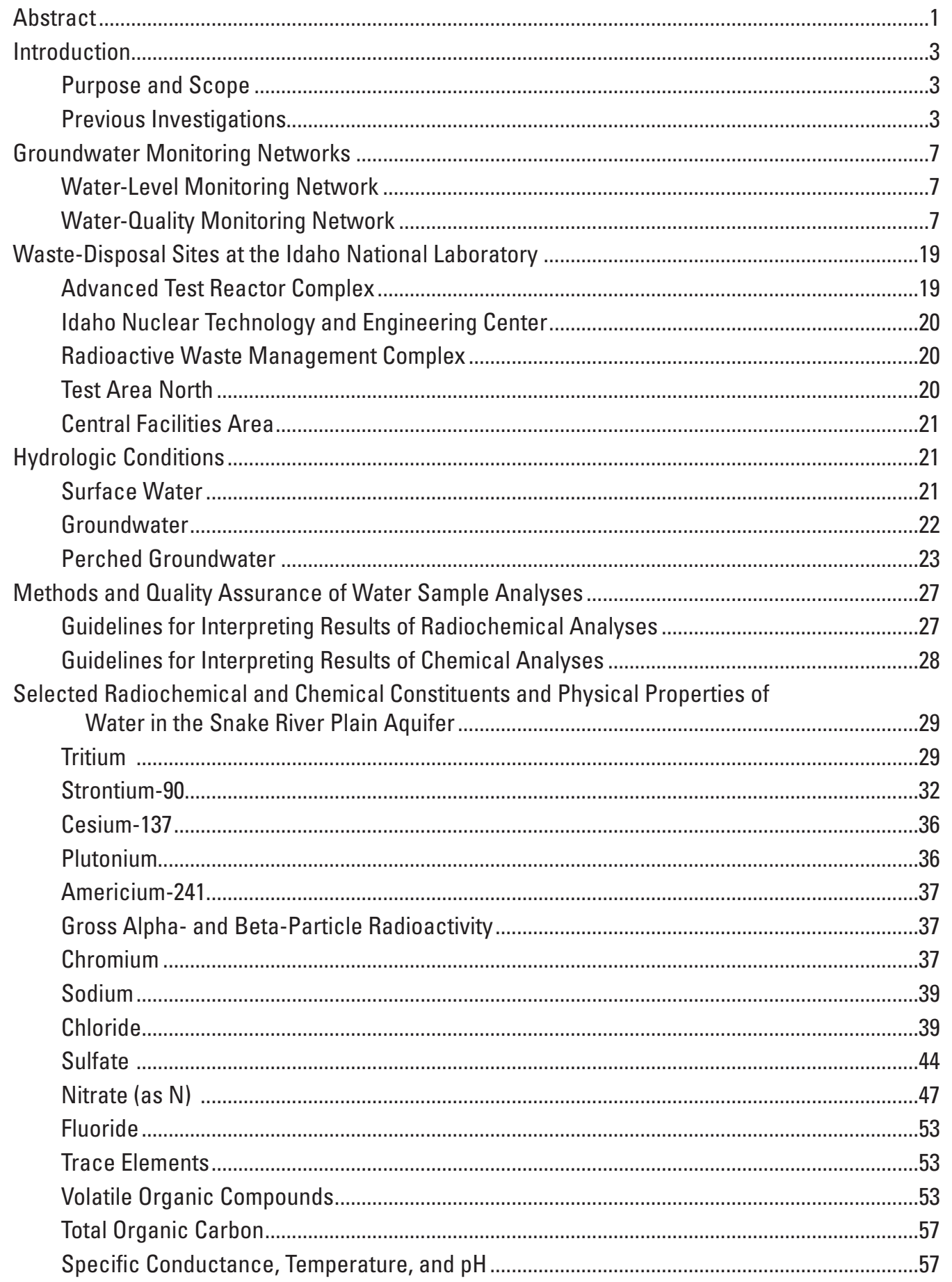




\section{Contents-Continued}

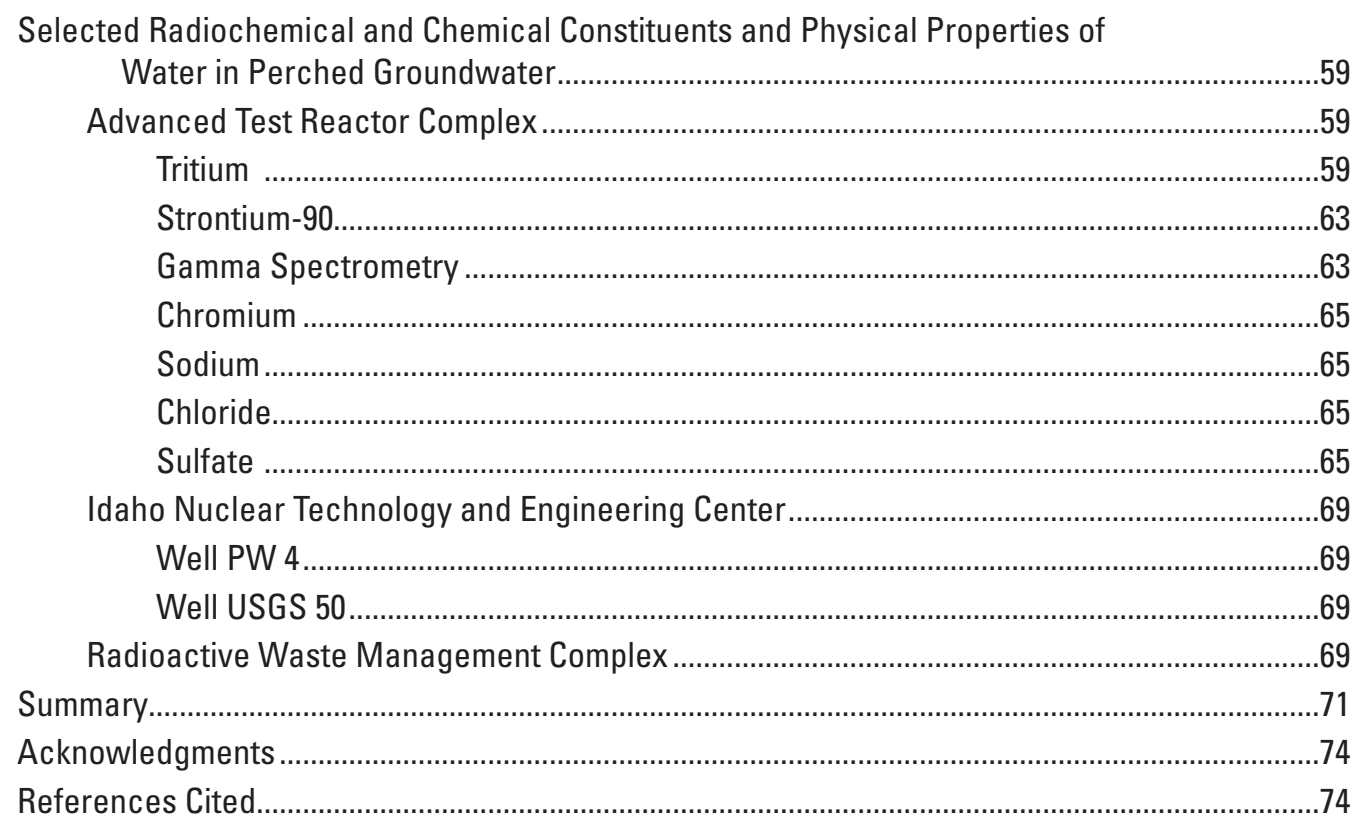

\section{Figures}

Figure 1. Map showing location of the Idaho National Laboratory, surface-water gaging stations, and selected facilities, Idaho

Figure 2. Map showing location of wells in the U.S. Geological Survey aquifer water-level monitoring network at and near the Idaho National Laboratory (INL), Idaho, and frequency of water-level measurements, as of December 2008

Figure 3. Map showing location of wells in the U.S. Geological Survey aquifer water-level monitoring network at the Advanced Test Reactor Complex (ATRC), Idaho Nuclear Technology and Engineering Center (INTEC), and Radioactive Waste Management Complex (RWMC), Idaho National Laboratory (INL), Idaho, and frequency of water-level measurements, as of December 2008

Figure 4. Map showing location of wells in the U.S. Geological Survey perched groundwater-level monitoring network at the Advanced Test Reactor Complex (ATRC), Idaho Nuclear Technology and Engineering Center (INTEC), and Radioactive Waste Management Complex (RWMC), Idaho National Laboratory (INL), Idaho, and frequency of water-level measurements, as of December 2008

Figure 5. Map showing location of wells in the U.S. Geological Survey aquifer water-quality monitoring network, Idaho National Laboratory (INL) and vicinity, Idaho, and frequency of water-sample collections, as of December 2008

Figure 6. Map showing location of wells in the U.S. Geological Survey aquifer water-quality monitoring network at the Advanced Test Reactor Complex (ATRC), Idaho Nuclear Technology and Engineering Center (INTEC), and Radioactive Waste Management Complex (RWMC), Idaho National Laboratory (INL), Idaho, and frequency of water-sample collections, as of December 2008 


\section{Figures-Continued}

Figure 7. Map showing location of wells in the U.S. Geological Survey perched groundwater-quality monitoring network at the Advanced Test Reactor

Complex (ATRC), Idaho Nuclear Technology and Engineering Center (INTEC), and Radioactive Waste Management Complex (RWMC), Idaho National Laboratory (INL), Idaho, and frequency of water-sample collections, as of December 2008 .....

Figure 8. Graphs showing streamflow at gaging stations along the Big Lost River ...... 22

Figure 9. Map showing altitude of the water table in the Snake River Plain aquifer at and near the Idaho National Laboratory, Idaho, March-May 2008

Figure 10. Map showing generalized rise or decline in groundwater levels in the Snake River Plain aquifer at and near Idaho National Laboratory (INL), Idaho, March-May 2005 to March-May 2008

Figure 11. Hydrographs showing water levels in four wells (USGS 12, 17, 20,23) in the central part of the Idaho National Laboratory, Idaho, 1952-2008

Figure 12. Map showing distribution of tritium in water from wells at and near the Advanced Test Reactor Complex, Idaho Nuclear Technology and Engineering Center, Central Facilities Area, and Radioactive Waste Management Complex at the Idaho National Laboratory, Idaho, April or October 2008

Figure 13. Graphs showing tritium concentrations in water from six wells at and near the Central Facilities Areas (CFA) and Idaho Nuclear Technology and Engineering Center (INTEC), 1980-2008

Figure 14. Map showing distribution of strontium-90 in water from wells at and near the Advanced Test Reactor Complex (ATRC), Idaho Nuclear Technology and Engineering Center (INTEC), Central Facilities Area (CFA), and Radioactive Waste Management Complex (RWMC), Idaho National Laboratory (INL), Idaho, April and October 2008

Figure 15. Graphs showing strontium-90 concentrations in water from seven wells at and near the Idaho Nuclear Technology and Engineering Center (INTEC), 1980-2008

Figure 16. Graphs showing vertical distribution of dissolved chromium in water from six wells equipped with multi-level Westbay ${ }^{\top \mathrm{M}}$ packer sampling systems, 2006-08

Figure 17. Graphs showing dissolved sodium concentrations in water from seven wells at and near the Idaho Nuclear Technology and Engineering Center (INTEC), 1980-2008

Figure 18. Graphs showing vertical distribution of dissolved sodium in water from six wells equipped with multi-level Westbay ${ }^{\top \mathrm{TM}}$ packer sampling systems, 2006-08

Figure 19. Map showing distribution of chloride in water from wells at and near the Advanced Test Reactor Complex (ATRC), Idaho Nuclear Technology and Engineering Center (INTEC), Central Facilities Area (CFA), and Radioactive Waste Management Complex (RWMC), Idaho National Laboratory (INL), Idaho, April or October 2008

Figure 20. Graphs showing dissolved chloride concentrations in water from seven wells at and near the Idaho Nuclear Technology and Engineering Center (INTEC), 1980-2008 


\section{Figures-Continued}

Figure 21. Graph and map showing amount of chloride in wastewater discharged to the disposal well and percolation ponds at the Idaho Nuclear Technology and Engineering Center (INTEC), flow direction, and the location and amount of chloride in water from wells USGS 37 and USGS 57, Idaho National Laboratory (INL), Idaho, 1971-2008

Figure 22. Graphs showing vertical distribution of dissolved chloride in water from six wells equipped with multi-level Westbay ${ }^{\mathrm{TM}}$ packer sampling systems, 2006-08

Figure 23. Graphs showing vertical distribution of dissolved sulfate in water from six wells equipped with multi-level Westbay ${ }^{\mathrm{TM}}$ packer sampling systems, 2006-08

Figure 24. Graphs showing concentration of nitrate (as N) in water from wells at and near the Idaho Nuclear Technology and Engineering Center (INTEC), 1981-2008

Figure 25. Graphs showing concentration of nitrate (as N) in water from wells south of the Idaho Nuclear Technology and Engineering Center (INTEC), 1981-2008

Figure 26. Map showing distribution of nitrate (as $\mathrm{N}$ ) in water from wells at and near the Advanced Test Reactor Complex (ATRC), Idaho Nuclear Technology and Engineering Center (INTEC), Central Facilities Area (CFA), and Radioactive Waste Management Complex (RWMC), Idaho National Laboratory (INL), Idaho, April or October 2008

Figure 27. Graphs showing vertical distribution of nitrate (as N) in water from six wells equipped with multi-level Westbay ${ }^{\top \mathrm{TM}}$ packer sampling systems, 2006-08

Figure 28. Graphs showing vertical distribution of fluoride in water from six wells equipped with multi-level Westbay ${ }^{\mathrm{TM}}$ packer sampling systems, 2006-08

Figure 29. Graph showing carbon tetrachloride concentrations in water from the Radioactive Waste Management Complex (RWMC) Production Well, Idaho National Laboratory (INL), Idaho, 1987-2008

Figure 30. Map showing distribution of specific conductance of water from wells at and near the Advanced Test Reactor Complex (ATRC), Naval Reactors Facility (NRF), and Idaho Nuclear Technology and Engineering Center (INTEC), Central Facilities Area (CFA), and Radioactive Waste Management Complex (RWMC), Idaho National Laboratory (INL), Idaho, April or October 2008

Figure 31. Map showing concentrations of tritium in water from wells completed in deep perched groundwater, Advanced Test Reactor Complex, Idaho National Laboratory, Idaho, April or October 2008

Figure 32. Map showing concentrations of strontium-90 in water from wells completed in deep perched groundwater, Advanced Test Reactor Complex, Idaho National Laboratory, Idaho, April or October 2008

Figure 33. Map showing concentrations of dissolved chromium in water from wells completed in deep perched groundwater, Advanced Test Reactor Complex, Idaho National Laboratory, Idaho, April or October 2008 


\section{Tables}

Table 1. Summary of selected previous investigations on geology, hydrology, and water characteristics of groundwater and perched groundwater, Idaho National Laboratory, Idaho, 1961-2010

Table 2. Construction of wells in the U.S. Geological Survey aquifer water-quality monitoring network and water sample-collection method, eastern Snake River Plain aquifer, Idaho National Laboratory, Idaho, as of December 2008 ....

Table 3. Construction of wells in the U.S. Geological Survey perched groundwaterquality monitoring network and water sample-collection method at the Advanced Test Reactor Complex, Idaho Nuclear Technology and Engineering Center, and Radioactive Waste Management Complex, Idaho National Laboratory, Idaho, as of December 2008

Table 4. Average annual streamflow at U.S. Geological Survey streamflow-gaging stations along the Big Lost River, Idaho, water years 2006-08

Table 5. Tritium concentrations in water sampled at multiple depths in six wells equipped with multi-level Westbay ${ }^{\mathrm{TM}}$ packer sampling systems, 2006-08

Table 6. Trace elements disposed during various periods, number of wells sampled, and range of concentrations detected, Idaho National Laboratory, Idaho, 2006-08 _. 55

Table 7. Concentrations of tritium, strontium-90, and cesium-137 in perched groundwater from selected wells, Advanced Test Reactor Complex, Idaho National Laboratory, Idaho, 2006-08

Table 8. Concentrations of selected dissolved ions in perched groundwater from selected wells, Advanced Test Reactor Complex, Idaho National Laboratory, Idaho, 2006-08

Table 9. Concentrations of tritium, strontium-90, cesium-137, selected transuranic elements, and dissolved chloride in perched groundwater from well USGS 92, Radioactive Waste Management Complex, Idaho National Laboratory, Idaho, 2006-08

Table 10. Concentrations of selected volatile organic compounds in perched groundwater from well USGS 92, Radioactive Waste Management Complex, Idaho National Laboratory, Idaho, April 23, 2007 


\section{Conversion Factors, Datums, and Abbreviations and Acronyms}

Conversion Factors

Inch/Pound to SI

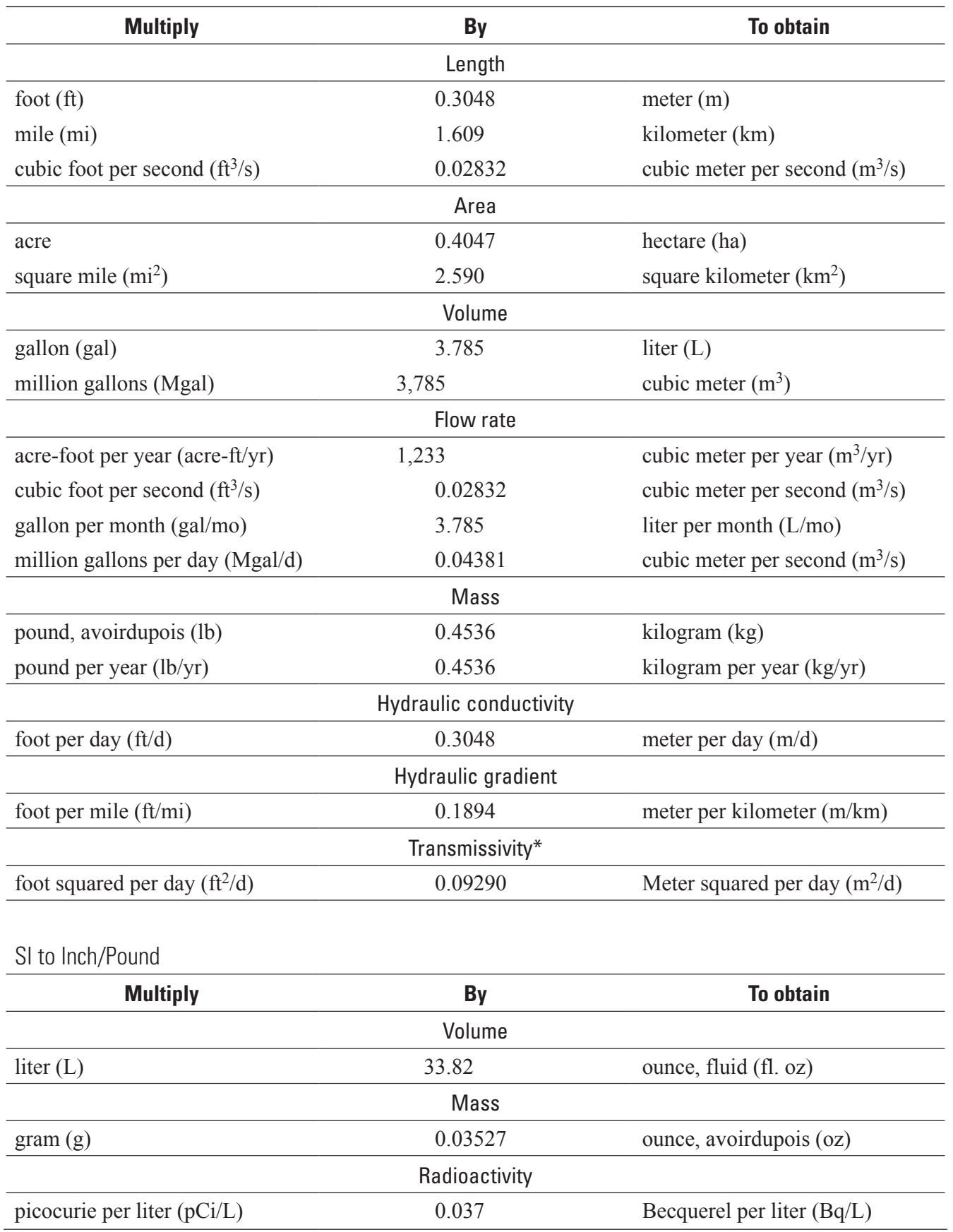


Temperature in degrees Celsius $\left({ }^{\circ} \mathrm{C}\right)$ may be converted to degrees Fahrenheit $\left({ }^{\circ} \mathrm{F}\right)$ as follows:

$$
{ }^{\circ} \mathrm{F}=\left(1.8 \mathrm{x}^{\circ} \mathrm{C}\right)+32 .
$$

Specific conductance is given in microsiemens per centimeter at 25 degrees Celsius $(\mu \mathrm{S} / \mathrm{cm}$ at $\left.25^{\circ} \mathrm{C}\right)$.

Concentrations of chemical constituents in water are given either in milligrams per liter (mg/L) or micrograms per liter $(\mu \mathrm{g} / \mathrm{L})$.

Concentrations of radiochemical constituents in water are given in picocuries per liter (pCi/L).

*Transmissivity: The standard unit is cubic foot per day per square foot times foot of aquifer thickness [(ft3 $\left./ \mathrm{d}) / \mathrm{ft}^{2}\right] \mathrm{ft}$. In this report, the mathematically reduced form, foot squared per day $\left(\mathrm{ft}^{2} / \mathrm{d}\right)$, is used for convenience.

\section{Datums}

Vertical coordinate information is referenced to the North American Vertical Datum of 1929 (NGVD 29).

Horizontal coordinate information is referenced to the North American Datum of 1927 (NAD 27).

Altitude, as used in this report, refers to distance above the vertical datum.

Abbreviations and Acronyms

\begin{tabular}{|c|c|}
\hline $\begin{array}{l}\text { Abbreviation or } \\
\text { Acronym }\end{array}$ & Definition \\
\hline ATRC & $\begin{array}{l}\text { Advanced Test Reactor Complex (formerly RTC, Reactor Technology Complex, and TRA, } \\
\text { Test Reactors Facility) }\end{array}$ \\
\hline CFA & Central Facilities Area \\
\hline DOE & Department of Energy \\
\hline ICPP & Idaho Chemical Processing Plant \\
\hline INEL & Idaho National Engineering Laboratory (1974-97) \\
\hline INEEL & Idaho National Engineering and Environmental Laboratory (1997-2005) \\
\hline INL & Idaho National Laboratory \\
\hline INTEC & Idaho Nuclear Technology and Engineering Center \\
\hline LRL & laboratory reporting level \\
\hline LT-MDL & long-term method detection level \\
\hline MCL & maximum contaminant level \\
\hline MFC & Materials and Fuels Complex \\
\hline MRL & minimum reporting level \\
\hline NRF & Naval Reactors Facility \\
\hline NRTS & National Reactor Testing Station (1949-74) \\
\hline NWIS & National Water Information System \\
\hline NWQL & National Water Quality Laboratory (USGS) \\
\hline PBF & Power Burst Facility \\
\hline RESL & Radiological and Environmental Sciences Laboratory (DOE) \\
\hline RWMC & Radioactive Waste Management Complex \\
\hline RWMC PROD & RWMC production well \\
\hline $\boldsymbol{s}$ & sample standard deviation \\
\hline SDA & Subsurface Disposal Area \\
\hline TAN & Test Area North \\
\hline TSF & Technical Support Facility \\
\hline TOC & total organic carbon \\
\hline USGS & U.S. Geological Survey \\
\hline VOC & volatile organic compound \\
\hline
\end{tabular}


This page intentionally left blank. 


\title{
An Update of Hydrologic Conditions and Distribution of Selected Constituents in Water, Snake River Plain Aquifer and Perched Groundwater Zones, Idaho National Laboratory, Idaho, Emphasis 2006-08
}

\author{
By Linda C. Davis
}

\section{Abstract}

Since 1952, radiochemical and chemical wastewater discharged to infiltration ponds (also called percolation ponds), evaporation ponds, and disposal wells at the Idaho National Laboratory (INL) has affected water quality in the eastern Snake River Plain aquifer and perched groundwater zones underlying the INL. The U.S. Geological Survey, in cooperation with the U.S. Department of Energy, maintains groundwater monitoring networks at the INL to determine hydrologic trends, and to delineate the movement of radiochemical and chemical wastes in the aquifer and in perched groundwater zones. This report presents an analysis of water-level and water-quality data collected from aquifer and perched groundwater wells in the USGS groundwater monitoring networks during 2006-08.

Water in the Snake River Plain aquifer primarily moves through fractures and interflow zones in basalt, generally flows southwestward, and eventually discharges at springs along the Snake River. The aquifer primarily is recharged from infiltration of irrigation water, infiltration of streamflow, groundwater inflow from adjoining mountain drainage basins, and infiltration of precipitation.

From March-May 2005 to March-May 2008, water levels in wells generally remained constant or rose slightly in the southwestern corner of the INL. Water levels declined in the central and northern parts of the INL. The declines ranged from about 1 to 3 feet in the central part of the INL, to as much as 9 feet in the northern part of the INL. Water levels in perched groundwater wells around the Advanced Test Reactor Complex (ATRC) also declined.

Detectable concentrations of radiochemical constituents in water samples from wells in the Snake River Plain aquifer at the INL generally decreased or remained constant during 2006-08. Decreases in concentrations were attributed to decreased rates of radioactive-waste disposal, radioactive decay, changes in waste-disposal methods, and dilution from recharge and underflow. In April or October 2008, reportable concentrations of tritium in groundwater ranged from $810 \pm 70$ to $8,570 \pm 190$ picocuries per liter $(\mathrm{pCi} / \mathrm{L})$, and the tritium plume extended south-southwestward in the general direction of groundwater flow. Tritium concentrations in water from wells completed in shallow perched groundwater at the ATRC were less than the reporting levels. Tritium concentrations in deep perched groundwater exceeded the reporting level in 11 wells during at least one sampling event during 2006-08 at the ATRC. Tritium concentrations from one or more zones in each well were reportable in water samples collected at various depths in six wells equipped with multi-level Westbay ${ }^{\mathrm{TM}}$ packer sampling systems.

Concentrations of strontium-90 in water from 24 of 52 aquifer wells sampled during April or October 2008 exceeded the reporting level. Concentrations ranged from $2.2 \pm 0.7$ to $32.7 \pm 1.2 \mathrm{pCi} / \mathrm{L}$. Strontium- 90 has not been detected within the eastern Snake River Plain aquifer beneath the ATRC partly because of the exclusive use of waste-disposal ponds and lined evaporation ponds rather than using the disposal well for radioactive-wastewater disposal at ATRC. At the ATRC, the strontium-90 concentration in water from one well completed in shallow perched groundwater was less than the reporting level. During at least one sampling event during 2006-08, concentrations of strontium-90 in water from nine wells completed in deep perched groundwater at the ATRC were greater than reporting levels. Concentrations ranged from $2.1 \pm 0.7$ to $70.5 \pm 1.8 \mathrm{pCi} / \mathrm{L}$. At the Idaho Nuclear Technology and Engineering Center (INTEC), the reporting level was exceeded in water from two wells completed in deep perched groundwater. During 2006-08, concentrations of cesium-137, plutonium-238, and plutonium-239, -240 (undivided), and americium-241 were less than the reporting level in water samples from all wells and all zones in wells equipped with multi-level Westbay ${ }^{\mathrm{TM}}$ packer sampling systems at the INL. 
The concentration of chromium in water from one well south of the ATRC steadily decreased from 2006 to 2008 and was 93 micrograms per liter $(\mu \mathrm{g} / \mathrm{L})$ in 2008 , just less than the maximum contaminant level (MCL). Concentrations in water samples from other wells ranged from 1.2 to $28.3 \mu \mathrm{g} / \mathrm{L}$. During 2006-08, chromium was detected in one well completed in shallow perched groundwater at a concentration of $3 \mu \mathrm{g} / \mathrm{L}$. Dissolved chromium was detected in water from 14 wells completed in deep perched groundwater at the ATRC during 2006-08.

Concentrations of sodium in water from wells south of the INTEC during 2006-08 generally were equal to or less than sodium concentrations detected in October 2005, with the exception of concentrations in water from well USGS 47 which was slightly higher in 2008 than in 2005. In October 2008, sodium concentrations in water from two wells near the Radioactive Waste Management Complex (RWMC) were 45 and 26 milligrams per liter $(\mathrm{mg} / \mathrm{L})$, slightly higher than the October 2005 concentrations. During 2006-08, analyses were not made for dissolved sodium concentrations in shallow perched groundwater at the ATRC. During April or October 2008, dissolved sodium concentrations in water from 16 wells completed in deep perched groundwater ranged from 6 to $23 \mathrm{mg} / \mathrm{L}$; concentration in water from one well was $476 \mathrm{mg} / \mathrm{L}$. The vertical distribution of sodium concentrations in wells equipped with Westbay ${ }^{\mathrm{TM}}$ systems were fairly consistent with depth, with the exception of sodium concentrations in water from well USGS 132, which were much higher (26-30 mg/L) in the uppermost zone than in the deeper zones $(9-12 \mathrm{mg} / \mathrm{L})$.

Chloride concentrations in water from wells near the INTEC generally decreased since the late 1990s. During 2006-08, concentrations in most wells either generally were constant or increased slightly. Trends in concentrations in water from wells downgradient from the percolation ponds correlated with discharge rates into the ponds when travel time was considered. During 2008, chloride concentrations in water from wells USGS 88 and 89 at the RWMC were 91 and $41 \mathrm{mg} / \mathrm{L}$. Concentrations of chloride in all other wells near the RWMC ranged from 11 to $25 \mathrm{mg} / \mathrm{L}$. In 2008, concentrations in water from all wells at or near the ATRC ranged between 10 and $18 \mathrm{mg} / \mathrm{L}$. During April 2008, dissolved chloride concentrations in shallow perched groundwater near the ATRC ranged from 11 to $13 \mathrm{mg} / \mathrm{L}$; concentrations in deep perched groundwater during April or October 2008 ranged from 4 to $43 \mathrm{mg} / \mathrm{L}$.

In 2008, sulfate concentrations ranged from 40 to $157 \mathrm{mg} / \mathrm{L}$ in water samples from nine aquifer wells in the south-central part of the INL, which exceeds the $40-\mathrm{mg} / \mathrm{L}$ background concentration of sulfate. The greater-thanbackground concentrations of sulfate in water from these wells probably resulted from sulfate disposal at the ATRC infiltration ponds. In October and April 2008, sulfate concentrations in water samples from two wells near the
RWMC were greater than background levels and could have resulted from the well construction and (or) waste disposal at the RWMC. During 2007-08, sulfate concentrations from three wells southwest of the INTEC were 45,47 , and $46 \mathrm{mg} / \mathrm{L}$. The maximum dissolved sulfate concentration in shallow perched groundwater near the ATRC was $399 \mathrm{mg} / \mathrm{L}$ in well CWP 1 in November 2006. During April-October 2008, the maximum concentration of dissolved sulfate in deep perched groundwater was $1,477 \mathrm{mg} / \mathrm{L}$ in well USGS 68 , which is located west of the chemical-waste pond. Concentrations of sulfate in two wells completed in deep perched groundwater near the INTEC were 36 and $39 \mathrm{mg} / \mathrm{L}$. Overall the vertical distribution of sulfate in water from wells equipped with Westbay ${ }^{\mathrm{TM}}$ systems generally was consistent in most zones in wells during 2006-08.

The regional background concentration for nitrate (as N) is about $1 \mathrm{mg} / \mathrm{L}$. In October 2008, concentrations of nitrate (as N) in water from most wells at and near the INTEC exceeded the background concentration and ranged from 2.2 to $5.97 \mathrm{mg} / \mathrm{L}$. Near the ATRC, the concentration of nitrate (as N) in water from well USGS 65 was $1.5 \mathrm{mg} / \mathrm{L}$. In 2008, concentrations of nitrate (as N) in water from wells USGS 88,89 , and 119 were $0.9,1.7$, and $1.4 \mathrm{mg} / \mathrm{L}$, respectively. All concentrations measured in aquifer wells at the INL in 2008 were less than the MCL for drinking water of $10 \mathrm{mg} / \mathrm{L}$ as N, with the exception of a concentration of $18.9 \mathrm{mg} / \mathrm{L}$ from well USGS 50 at the INTEC.

During April or October 2008, fluoride concentrations in water samples from four aquifer wells ranged from 0.2 to $0.3 \mathrm{mg} / \mathrm{L}$. These concentrations are similar to the background concentrations, which indicate that wastewater disposal has not appreciably affected fluoride concentrations in the Snake River Plain aquifer near the INTEC.

During 2006-08, water samples from 30 aquifer wells were collected and analyzed for volatile organic compounds (VOCs). Twelve VOCs were detected. Concentrations of from 1 to 10 VOCs were detected in water samples from 11 wells. Primary VOCs detected included carbon tetrachloride, trichloromethane, 1,1-dichloroethane, 1,1,1-trichloroethane, trichloroethylene, and tetrachloroethylene.

During April or October 2008, water samples from 50 wells completed in the Snake River Plain aquifer at the INL were analyzed for total organic carbon (TOC); detected concentrations ranged from 0.43 to $1.9 \mathrm{mg} / \mathrm{L}$.

Well USGS 92 is in the Subsurface Disposal Area (SDA) at the RWMC and is completed in a sedimentary interbed $214 \mathrm{ft}$ below land surface. Perched groundwater in this well has moved through overlying sediments and basalt, and may contain waste constituents leached from radiochemical and organic chemical wastes buried in the SDA. During 2006-08, tritium concentrations in water samples from well USGS 92 exceeded the reporting level and ranged from $490 \pm 110 \mathrm{pCi} / \mathrm{L}$ in April 2006 to $300 \pm 80 \mathrm{pCi} / \mathrm{L}$ in June 2008. Water from well 
USGS 92 was sampled for VOCs in April 2007, and 9 VOCs were detected which was a decrease from the 15 compounds detected in 2002-03. Additionally, all VOC concentrations detected in 2007 were significantly lower than those detected during 2002-03, with the exception of toluene, which was not detected in 2002-03.

\section{Introduction}

The Idaho National Laboratory (INL), operated by the U.S. Department of Energy (DOE), encompasses about $890 \mathrm{mi}^{2}$ of the eastern Snake River Plain in southeastern Idaho (fig. 1). Names formerly used for this site, from earliest to most recent, were National Reactor Testing Station (NRTS, 1949-1974), Idaho National Engineering Laboratory (INEL, 1974-1997), and Idaho National Engineering and Environmental Laboratory (INEEL, 1997-2005). The INL facilities are used in the development of peacetime atomic-energy applications, nuclear safety research, defense programs, environmental research, and advanced energy concepts.

Radiochemical and chemical wastewater generated at these facilities has been discharged to onsite infiltration ponds, evaporation ponds, disposal wells, or a combination thereof since 1952. Wastewater disposal has resulted in detectable concentrations of several waste constituents in water from the eastern Snake River Plain aquifer underlying the INL. Disposal of wastewater to infiltration ponds and infiltration of surface water at waste-burial sites resulted in the formation of perched groundwater in basalts and in sedimentary interbeds that overlie the Snake River Plain aquifer. Perched groundwater is an integral part of the pathway for wasteconstituent migration to the aquifer.

The DOE requires information about the mobility of dilute radiochemical- and chemical-waste constituents in the Snake River Plain aquifer and in perched groundwater above the aquifer to assess the impact of INL facility operations on water quality, and to aid in remediation activities. Waste-constituent mobility is determined, in part, by (1) the rate and direction of groundwater flow, (2) the locations, quantities, and methods of waste disposal, (3) waste-constituent chemistry, and (4) the geochemical processes taking place in the aquifer. This study was conducted by the U.S. Geological Survey (USGS) in cooperation with the DOE Idaho Operations Office.

\section{Purpose and Scope}

In 1949, the U.S. Atomic Energy Commission, which later became the DOE, requested that the USGS describe the water resources of the area now known as the INL. The purpose of the resulting study was to characterize these resources before the development of nuclear-reactor testing facilities. Since that time, the USGS has maintained water-level and water-quality monitoring networks at the INL to determine hydrologic trends and to delineate the movement of radiochemical and chemical wastes in the Snake River Plain aquifer and in perched groundwater.

Most of the wells in the USGS monitoring network were constructed as open boreholes and are open to the aquifer through their entire depth below the water table. Beginning in 2005, the USGS and the INL contractor collaborated to instrument two wells (Middle 2050A and Middle 2051) with multi-level Westbay ${ }^{\mathrm{TM}}$ packer sampling systems to collect water samples for analysis in order to describe the vertical distribution of constituents in the eastern Snake River Plain aquifer. The USGS expanded the program in 2006 and 2007 to include four additional wells (USGS 103, 132, 133, and 134). Various data were collected from these multi-level sampling systems during 2005-08 (Bartholomay and Twining, 2010).

This report presents an analysis of water-level and waterquality data collected from wells in the USGS groundwater monitoring networks during 2006-08 as part of the continuing hydrogeologic investigations conducted by the USGS at the INL. This report describes the distribution and concentration of selected radiochemical and chemical constituents in groundwater and perched groundwater at the INL, the vertical distribution of selected constituents from samples collected with multi-level Westbay ${ }^{\mathrm{TM}}$ systems, and the changes in the regional water-levels since 2005 . The report also summarizes the history of waste disposal at the Advanced Test Reactor Complex (ATRC; formerly known as the Test Reactor Area, TRA; and the Reactor Technology Complex, RTC), Idaho Nuclear Technology and Engineering Center (INTEC; formerly known as the Idaho Chemical Processing Plant, ICPP), Radioactive Waste Management Complex (RWMC), Test Area North (TAN), and the Central Facilities Area (CFA). Perched groundwater has been detected beneath infiltration ponds and ditches at other facilities at the INL in the past, but is not discussed in this report.

\section{Previous Investigations}

Hydrologic conditions and the distribution of selected wastewater constituents in groundwater and perched groundwater are discussed in a series of reports describing the INL. Table 1 summarizes selected previous investigations on the geology, hydrology, and water characteristics at and near the INL, and periods included in those investigations. Numerous previous investigations on the hydrology and geology at the INL have been done by INL contractors, state agencies, and the USGS. Copies of published reports for previous USGS studies at the INL are available from the USGS INL Project Office or the USGS Publications Warehouse Web site at http://pubs.er.usgs.gov/ (U.S. Geological Survey, 2010a). 

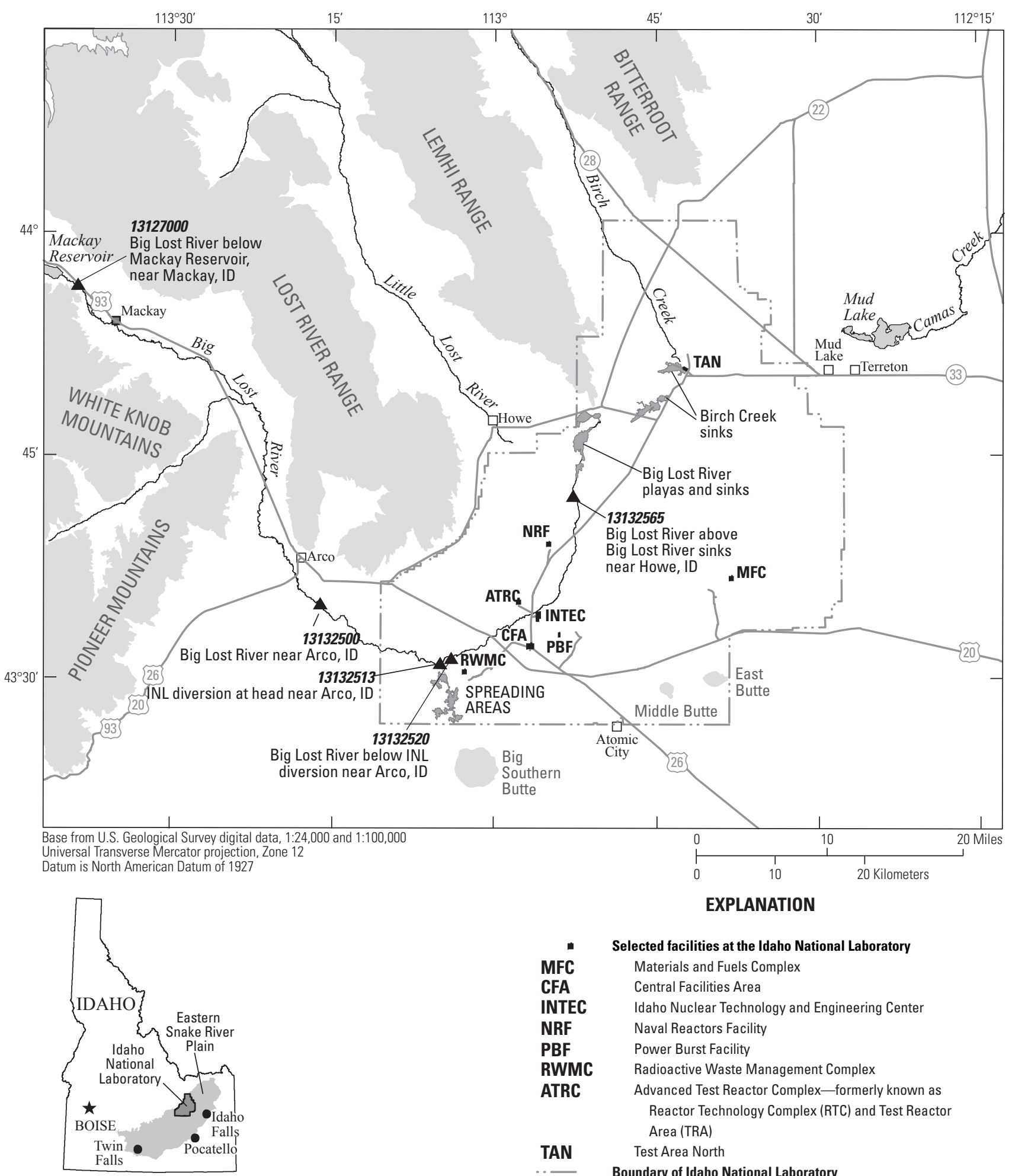

\begin{tabular}{ll} 
& Selected facilities at the Idaho National Laboratory \\
MFC & Materials and Fuels Complex \\
CFA & Central Facilities Area \\
INTEC & Idaho Nuclear Technology and Engineering Center \\
NRF & Naval Reactors Facility \\
PBF & Power Burst Facility \\
RWMC & Radioactive Waste Management Complex \\
ATRC & Advanced Test Reactor Complex-formerly known as \\
& Reactor Technology Complex (RTC) and Test Reactor \\
& Area (TRA) \\
TAN & Test Area North \\
\hdashline$\overline{13132513}$ Boundary of Idaho National Laboratory \\
USGS gaging station and number
\end{tabular}

Figure 1. Location of the Idaho National Laboratory, surface-water gaging stations, and selected facilities, Idaho. 
Table 1. Summary of selected previous investigations on geology, hydrology, and water characteristics of groundwater and perched groundwater, Idaho National Laboratory, Idaho, 1961-2010.

[Abbreviations: NRTS, National Reactor Testing Station; RWMC, Radioactive Waste Management Complex; INEL, Idaho National Engineering Laboratory; INEEL, Idaho National Engineering and Environmental Laboratory; INL, Idaho National Laboratory; TRA, Test Reactor Area; ICPP, Idaho Chemical Processing Plant]

\begin{tabular}{|c|c|c|}
\hline Reference & $\begin{array}{l}\text { Investigation } \\
\text { period }\end{array}$ & Summary \\
\hline \multicolumn{3}{|c|}{ Groundwater } \\
\hline Olmsted (1962) & & Chemical and physical character of groundwater at the NRTS, Idaho. \\
\hline Morris and others $(1963,1964,1965)$ & & Hydrology of waste disposal at the NRTS, Idaho. \\
\hline Barraclough and others (1967b) & 1966 & Hydrology of the NRTS, Idaho. \\
\hline Nace and others (1975) & & Generalized geologic framework of the NRTS, Idaho. \\
\hline Robertson and others (1974) & & $\begin{array}{l}\text { Effects of waste disposal on the geochemistry of groundwater at the NRTS, } \\
\text { Idaho. }\end{array}$ \\
\hline Barraclough and others (1976) & & Hydrology of the solid waste burial ground (now the RWMC). \\
\hline Pittman and others (1988) & $1982-85$ & Hydrologic conditions for the INEL, Idaho. \\
\hline Orr and Cecil (1991) & $1986-88$ & $\begin{array}{l}\text { Hydrologic conditions and distribution of selected chemical constituents in } \\
\text { water at the INEL, Idaho. }\end{array}$ \\
\hline Bartholomay and others (1995) & 1989-91 & $\begin{array}{l}\text { Hydrologic conditions and distribution of selected radiochemical and } \\
\text { chemical constituents in water, INEL, Idaho. }\end{array}$ \\
\hline Bartholomay and others (1997) & $1992-95$ & $\begin{array}{l}\text { Hydrologic conditions and distribution of selected radiochemical and } \\
\text { chemical constituents in water, INEL, Idaho. }\end{array}$ \\
\hline Bartholomay and others (2000) & 1996-98 & $\begin{array}{l}\text { Hydrologic conditions and distribution of selected constituents in water, } \\
\text { INEEL, Idaho. }\end{array}$ \\
\hline $\begin{array}{l}\text { Davis (2006b) } \\
\text { http://pubs.usgs.gov/sir/2006/5088/ }\end{array}$ & 1999-2001 & $\begin{array}{l}\text { Hydrologic conditions and distribution of selected radiochemical and } \\
\text { chemical constituents in water, INL, Idaho. }\end{array}$ \\
\hline \multicolumn{3}{|c|}{ Perched groundwater } \\
\hline Barraclough and others (1967a) & 1965 & $\begin{array}{l}\text { Extent of perched groundwater and distribution of selected wastewater } \\
\text { constituents in perched groundwater at the TRA. }\end{array}$ \\
\hline Barraclough and others (1967b) & 1966 & $\begin{array}{l}\text { Extent of perched groundwater and distribution of selected wastewater } \\
\text { constituents in perched groundwater at the TRA. }\end{array}$ \\
\hline
\end{tabular}


Table 1. Summary of selected previous investigations on geology, hydrology, and water characteristics of groundwater and perched groundwater, Idaho National Laboratory, Idaho, 1961-2010. - Continued

[Abbreviations: NRTS, National Reactor Testing Station; RWMC, Radioactive Waste Management Complex; INEL, Idaho National Engineering Laboratory; INEEL, Idaho National Engineering and Environmental Laboratory; INL, Idaho National Laboratory; TRA, Test Reactor Area; ICPP, Idaho Chemical Processing Plant]

\begin{tabular}{lcc}
\hline Reference & $\begin{array}{c}\text { Investigation } \\
\text { period }\end{array}$ & Summary \\
\hline & Perched groundwater-Continued
\end{tabular}

Perched groundwater-Continued

Robertson and others (1974)

Barraclough and Jensen (1976)

Robertson (1977)

Barraclough and others (1981)

Lewis and Jensen (1985)

Pittman and others (1988)

Hull (1989)

Anderson and Lewis (1989)

Anderson (1991)

Ackerman (1991)

Cecil and others (1991)

Tucker and Orr (1998)

Bartholomay (1998)

Orr (1999)

Bartholomay and Tucker (2000)

1996-98

Davis (2006a)

http://pubs.usgs.gov/sir/2006/5236/

Davis (2008)

http://pubs.usgs.gov/sir/2008/5089/
Analysis of perched groundwater and conditions related to the disposal of wastewater to the subsurface at the INEL.

Extent of perched groundwater and distribution of selected wastewater constituents in perched groundwater at the ATRC.

Numerical model simulating flow and transport of chemical and radionuclide constituents through perched groundwater at the ATRC.

1974-78 Hydrologic conditions for the INEL, Idaho.

1979-81 Hydrologic conditions for the INEL, Idaho.

1982-85 Hydrologic conditions for the INEL, Idaho.

Conceptual model that described migration pathways for wastewater and constituents from the radioactive-waste infiltration ponds at the TRA.

Correlation of drill cores and geophysical logs to describe a sequence of basalt flows and sedimentary interbeds in the unsaturated zones underlying the RWMC.

Correlation of drill cores and geophysical logs to describe a sequence of basalt flows and sedimentary interbeds in the unsaturated zones underlying the RTC, and INTEC.

Analyzed data from 43 aquifer tests conducted in 22 wells to estimate transmissivity of basalts and sedimentary interbeds containing perched groundwater beneath the TRA and INTEC.

1986-88 Mechanisms for formation of perched water at the TRA, ICPP, and RWMC, INEL, Idaho; distribution of chemical and radiochemical constituents in perched groundwater at the TRA, ICPP and RWMC.

1989-91 Hydrologic conditions and distribution of selected radiochemical and chemical constituents in perched groundwater, INEL, Idaho.

1992-95 Hydrologic conditions and distribution of selected radiochemical and chemical constituents in perched groundwater, INEL, Idaho.

Transient numerical simulation to evaluate a conceptual model of flow through perched water beneath wastewater infiltration ponds at the TRA.

Hydrologic conditions and distribution of selected radiochemical and chemical constituents in perched groundwater, INEEL, Idaho.

1999-2001 Hydrologic conditions and distribution of selected radiochemical and chemical constituents in perched groundwater, INL, Idaho.

2002-05 Hydrologic conditions and distribution of selected radiochemical and chemical constituents in groundwater and perched groundwater, INL, Idaho. 


\section{Groundwater Monitoring Networks}

The USGS maintains groundwater monitoring networks at the INL to characterize the occurrence, movement, and quality of water, and to delineate waste-constituent plumes in the Snake River Plain aquifer and perched groundwater zones. Periodic water-level and water-quality data are obtained from these networks. In addition, selected data are collected from multi-level Westbay ${ }^{\mathrm{TM}}$ packer sampling systems in order to describe the vertical distribution of selected constituents. Data from these monitoring networks are on file at the USGS INL Project Office and are available via the USGS National Water Information System (NWIS) Web site at http://waterdata.usgs. gov/id/nwis/nwis (U.S. Geological Survey, 2010b).

\section{Water-Level Monitoring Network}

The USGS aquifer water-level monitoring network was designed to determine hydraulic-gradient changes that affect the rate and direction of groundwater and wasteconstituent movement in the Snake River Plain aquifer, to identify sources of recharge to the aquifer, and to measure the effects of recharge. During 2005-07, six wells were equipped with multi-level Westbay ${ }^{\mathrm{TM}}$ packer sampling systems that allow pressure and temperature measurements to be acquired at isolated depths in each of the wells. This multi-level monitoring provided data used to describe the vertical distribution of pressure and temperature gradients in addition to the horizontal distribution information previously gathered from open boreholes. Water levels were monitored in 181 aquifer wells during 2006-08. Water levels were measured annually in 26 wells, semiannually in 59 wells, quarterly in 78 wells, monthly in 13 wells, and are continuously recorded in 5 wells. Figures 2 and 3 show the locations of aquifer wells and the frequency of water-level measurements as of December 2008.

The USGS perched groundwater-level monitoring network was designed so that the extent of perched groundwater and the volume of perched groundwater in storage could be estimated. Water levels in 30 wells (fig. 4) were monitored during 2006-08. At the ATRC, the network included 18 wells to monitor deep perched groundwater levels and 10 wells to monitor shallow perched groundwater levels. Shallow perched groundwater is considered to be water perched in surficial sediment deposits, and deep perched groundwater is water perched at greater depth. Perching mechanisms are attributed to contrasting hydraulic properties between sedimentary interbeds and basalts or between low-permeability basalt-flow interiors and overlying fractured basalt. At the INTEC, the network included one well to monitor deep perched groundwater levels around the INTEC disposal well. Perched groundwater at the RWMC was measured in one well. Well locations and frequency of water-level measurements as of December 2008 are shown in figure 4.

\section{Water-Quality Monitoring Network}

The radiochemical and chemical character of groundwater and perched groundwater in the Snake River Plain aquifer was determined from analyses of water samples collected as part of a comprehensive sampling program to identify contaminant concentrations and to define patterns of waste migration in the aquifer and perched zones. Water samples were collected from wells that penetrate the aquifer at various depths and with differing well completions, and the water samples were analyzed to identify trends in water quality. Numerous water samples were collected from groundwater and perched groundwater wells near areas of detailed study, such as the ATRC, INTEC, RWMC, TAN, and CFA. Water samples from the Naval Reactors Facility (NRF) were collected and analyzed as part of a separate study, and the results of that study are presented in series of separate reports (Bartholomay and others, 2001a, 2001b). Beginning in 2005, the USGS and the INL contractor collaborated to instrument two wells (Middle 2050A and Middle 2051; figs. 5 and $\underline{6}$ ) with multi-level Westbay ${ }^{\mathrm{TM}}$ packer sampling systems to collect water samples for analysis in order to describe the vertical distribution of constituents in the eastern Snake River Plain aquifer. The USGS expanded the program in 2006 and 2007 to instrument four additional wells (USGS 103, 132, 133, and 134; figs. 5 and $\underline{6}$ ). North Wind (2006) and B.V. Twining and J.C. Fisher, U.S. Geological Survey, written commun., (2010) give detailed descriptions of the installation of each well. Bartholomay and Twining (2010, table 1) describe the water sample port depth and associated intervals sampled with the Westbay ${ }^{\mathrm{TM}}$ packer sampling systems. Various data were collected from these multi-level sampling systems during 2005-08 (Bartholomay and Twining, 2010).

The type, frequency, and depth of groundwater sampling generally depend on the information needed in a specific area. Water samples were routinely collected and analyzed for concentrations of tritium, strontium-90, cesium-137, plutonium-238, plutonium-239, -240 (undivided), americium-241, gross alpha- and beta-particle radioactivity, chromium, sodium, chloride, sulfate, nitrate (as N), and volatile organic compounds, and measurements of specific conductance, $\mathrm{pH}$, and temperature. Additionally, as part of the INL groundwater monitoring program adopted in 1994 (Sehlke and Bickford, 1993), water samples from several wells also were analyzed for fluoride, an extensive suite of trace elements, and total organic carbon. A sample schedule that lists the constituents typically analyzed for is given in a report by Knobel and others (2008, appendix A).

The location and construction of wells, and the water sample collection method in the aquifer water-quality monitoring network as of December 2008, are shown in figures 5 and $\underline{6}$, and in table 2 . Well location and construction of wells in the USGS water-quality monitoring network for perched groundwater beneath INL facilities as of December 2008 are shown in figure 7 and table 3. All wells were scheduled to be sampled annually. 

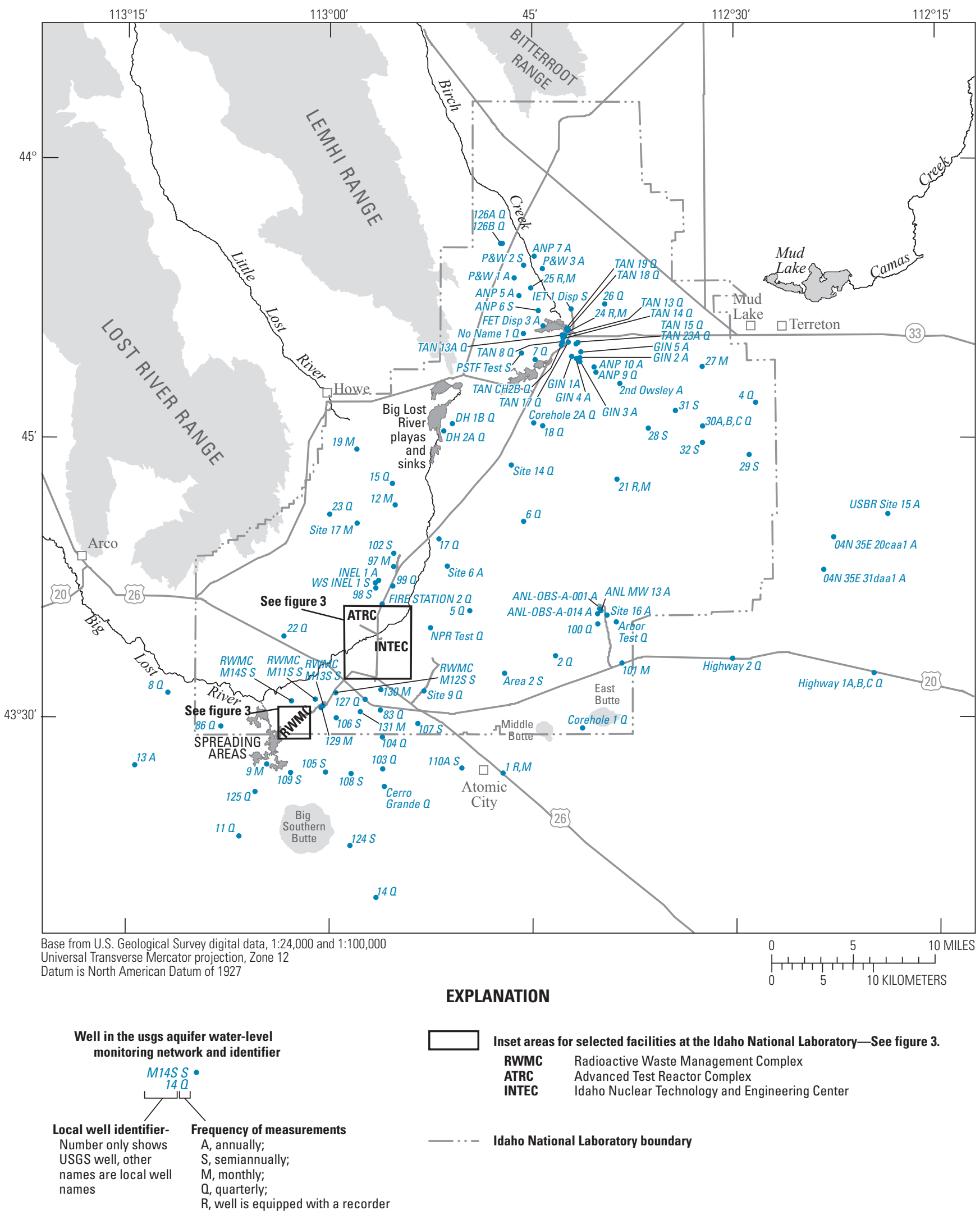

Inset areas for selected facilities at the Idaho National Laboratory-See figure 3.

RWMC Radioactive Waste Management Complex

ATRC Advanced Test Reactor Complex

INTEC Idaho Nuclear Technology and Engineering Center

Local well identifier- Frequency of measurements

Number only shows A, annually;

Idaho National Laboratory boundary

names are local well $\quad M$, monthly;

$R$, well is equipped with a recorder

Figure 2. Location of wells in the U.S. Geological Survey aquifer water-level monitoring network at and near the Idaho National Laboratory (INL), Idaho, and frequency of water-level measurements, as of December 2008. 


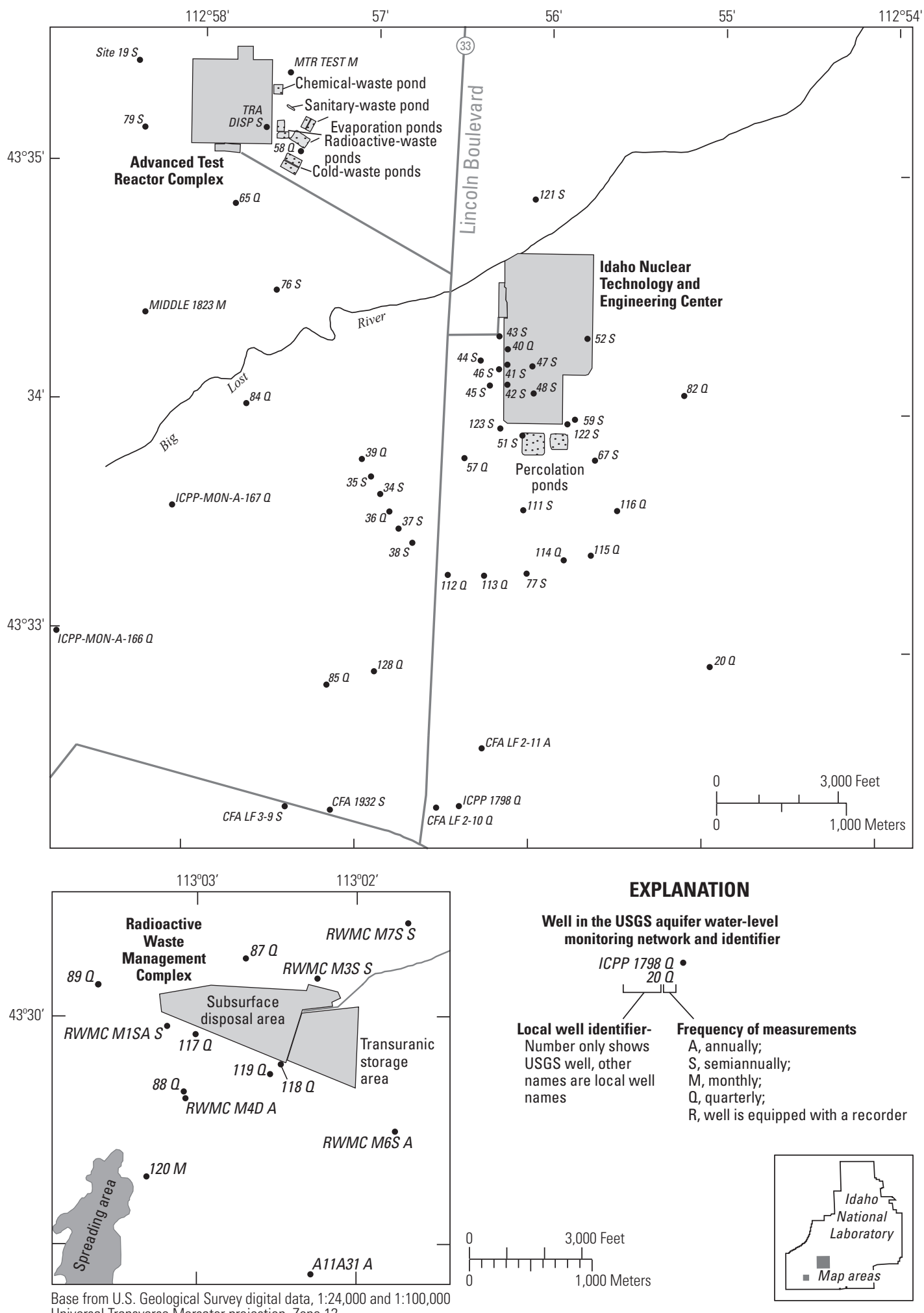

Base from U.S. Geological Survey digital data, 1:24,000 and 1:100,000 Universal Transverse Mercator projection, Zone 12

Datum is North American Datum of 1927

Figure 3. Location of wells in the U.S. Geological Survey aquifer water-level monitoring network at the Advanced Test Reactor Complex (ATRC), Idaho Nuclear Technology and Engineering Center (INTEC), and Radioactive Waste Management Complex (RWMC), Idaho National Laboratory (INL), Idaho, and frequency of water-level measurements, as of December 2008. 


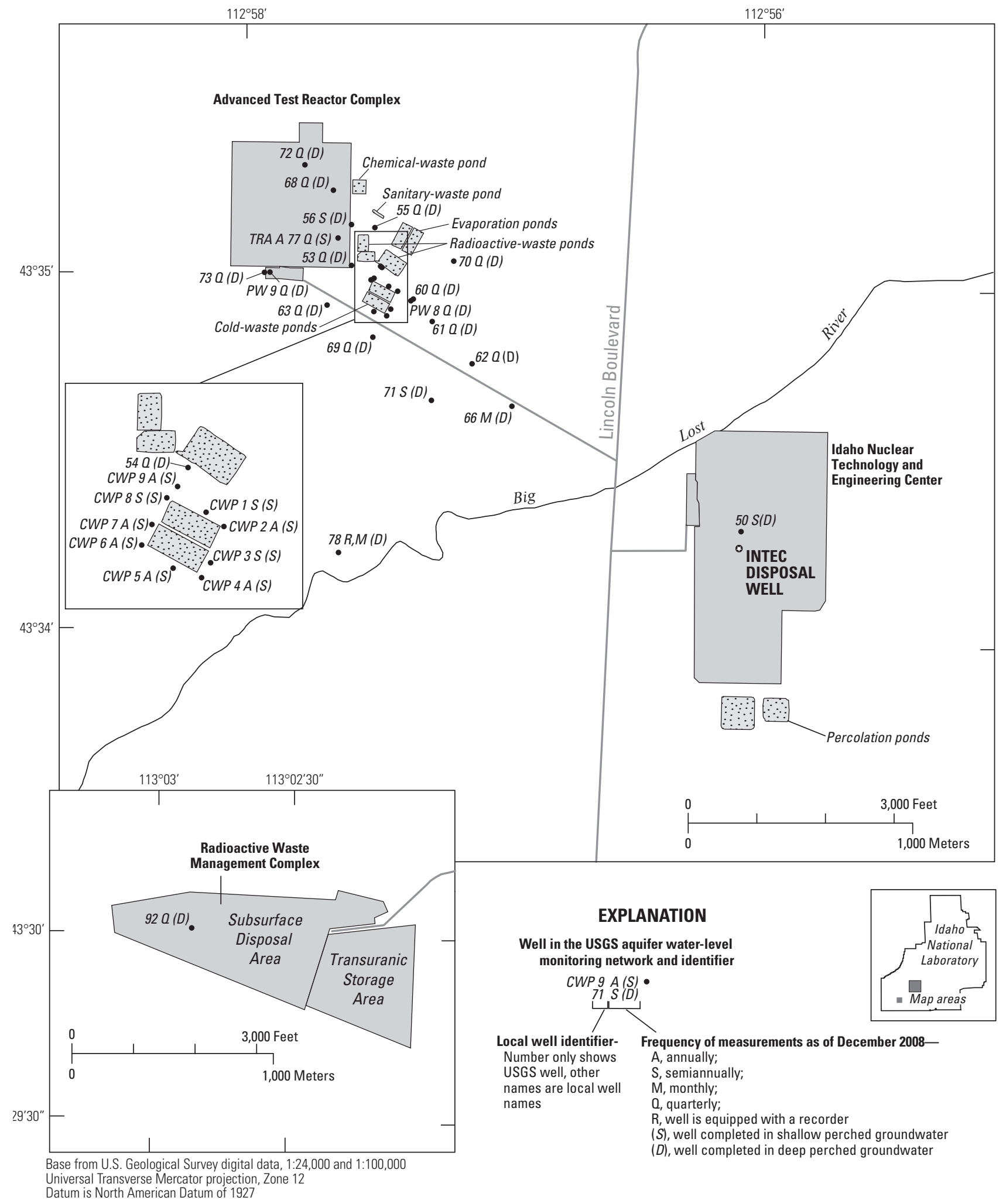

Figure 4. Location of wells in the U.S. Geological Survey perched groundwater-level monitoring network at the Advanced Test Reactor Complex (ATRC), Idaho Nuclear Technology and Engineering Center (INTEC), and Radioactive Waste Management Complex (RWMC), Idaho National Laboratory (INL), Idaho, and frequency of water-level measurements, as of December 2008. 


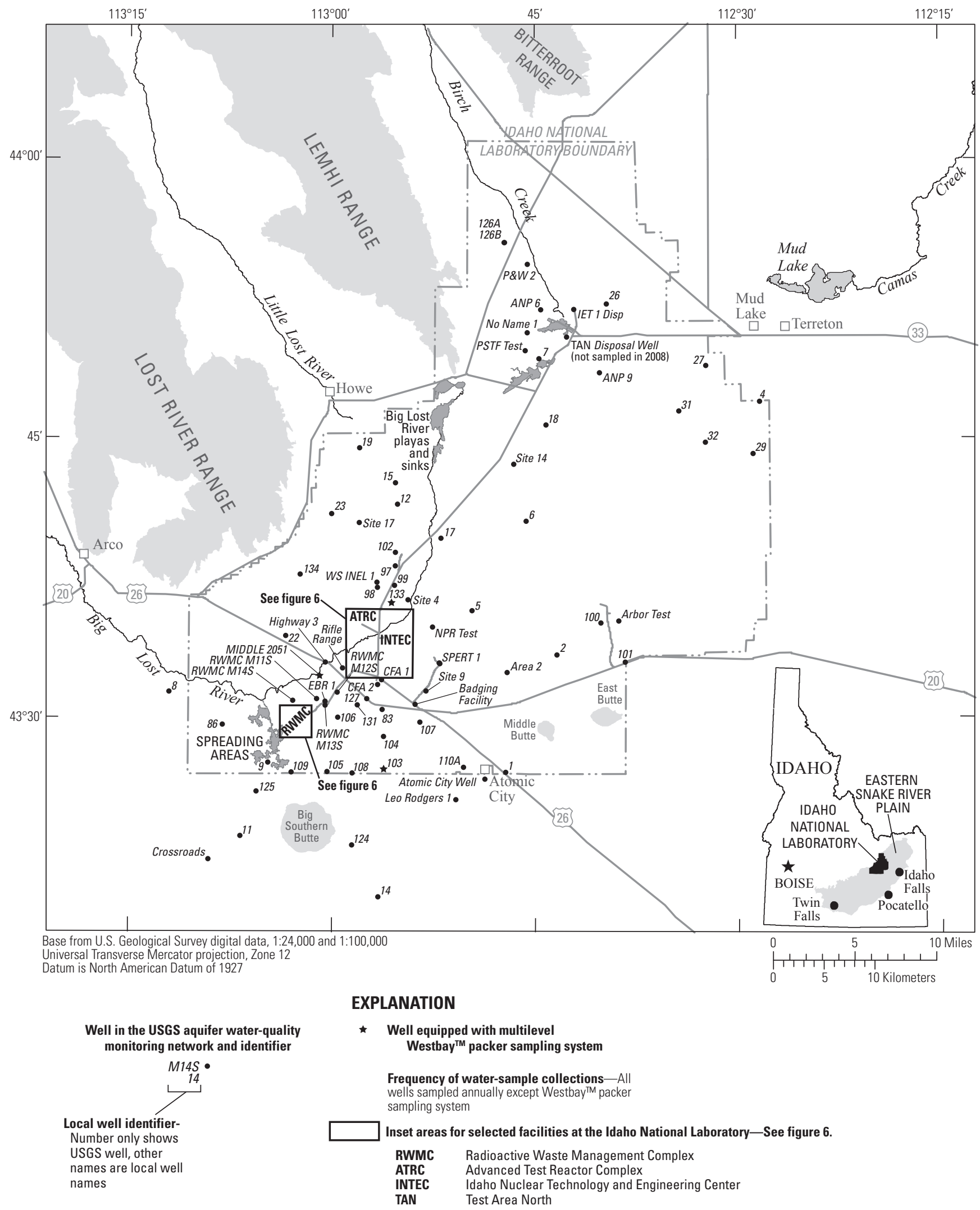

Figure 5. Location of wells in the U.S. Geological Survey aquifer water-quality monitoring network, Idaho National Laboratory (INL) and vicinity, Idaho, and frequency of water-sample collections, as of December 2008. 


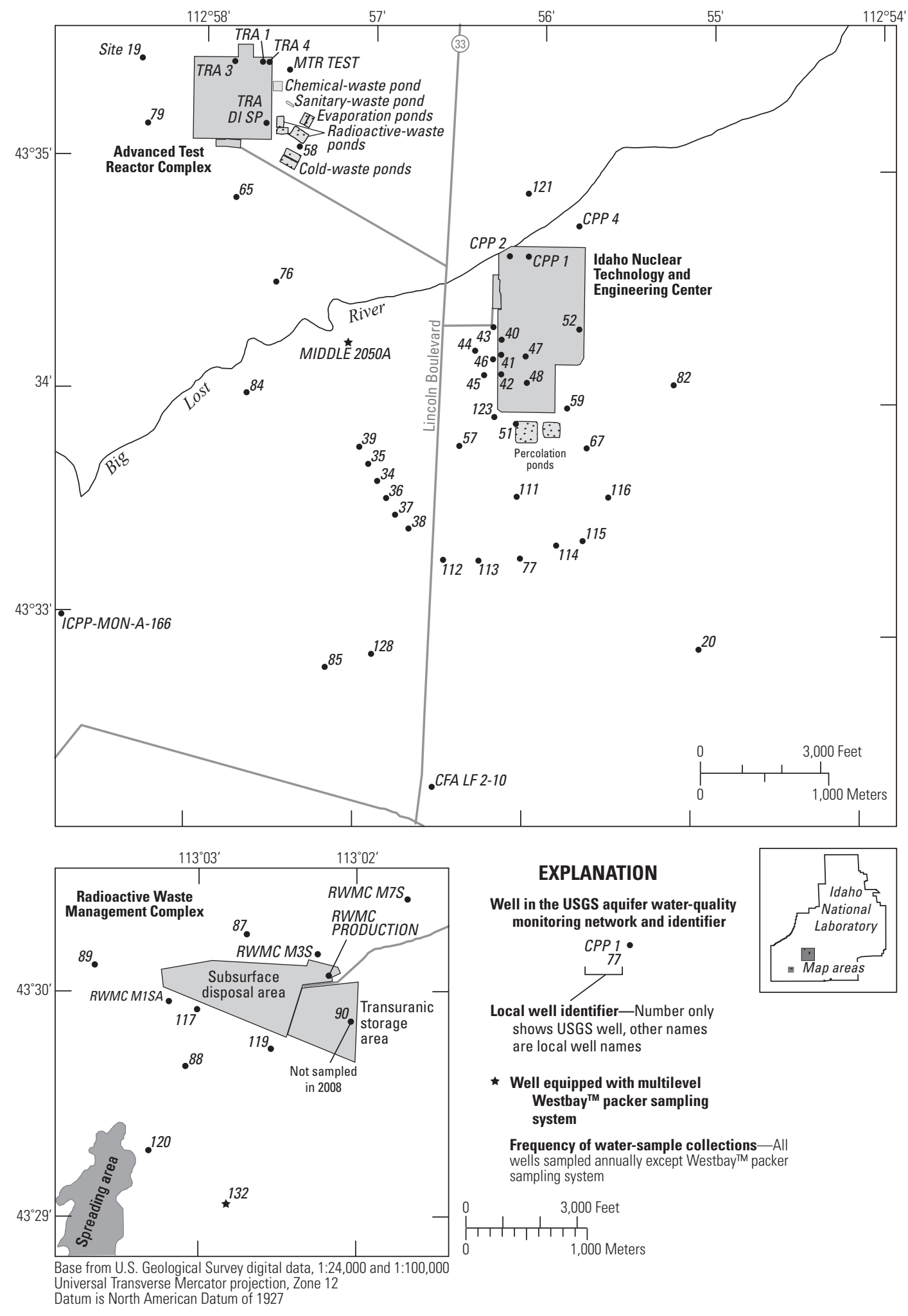

Figure 6. Location of wells in the U.S. Geological Survey aquifer water-quality monitoring network at the Advanced Test Reactor Complex (ATRC), Idaho Nuclear Technology and Engineering Center (INTEC), and Radioactive Waste Management Complex (RWMC), Idaho National Laboratory (INL), Idaho, and frequency of water-sample collections, as of December 2008. 


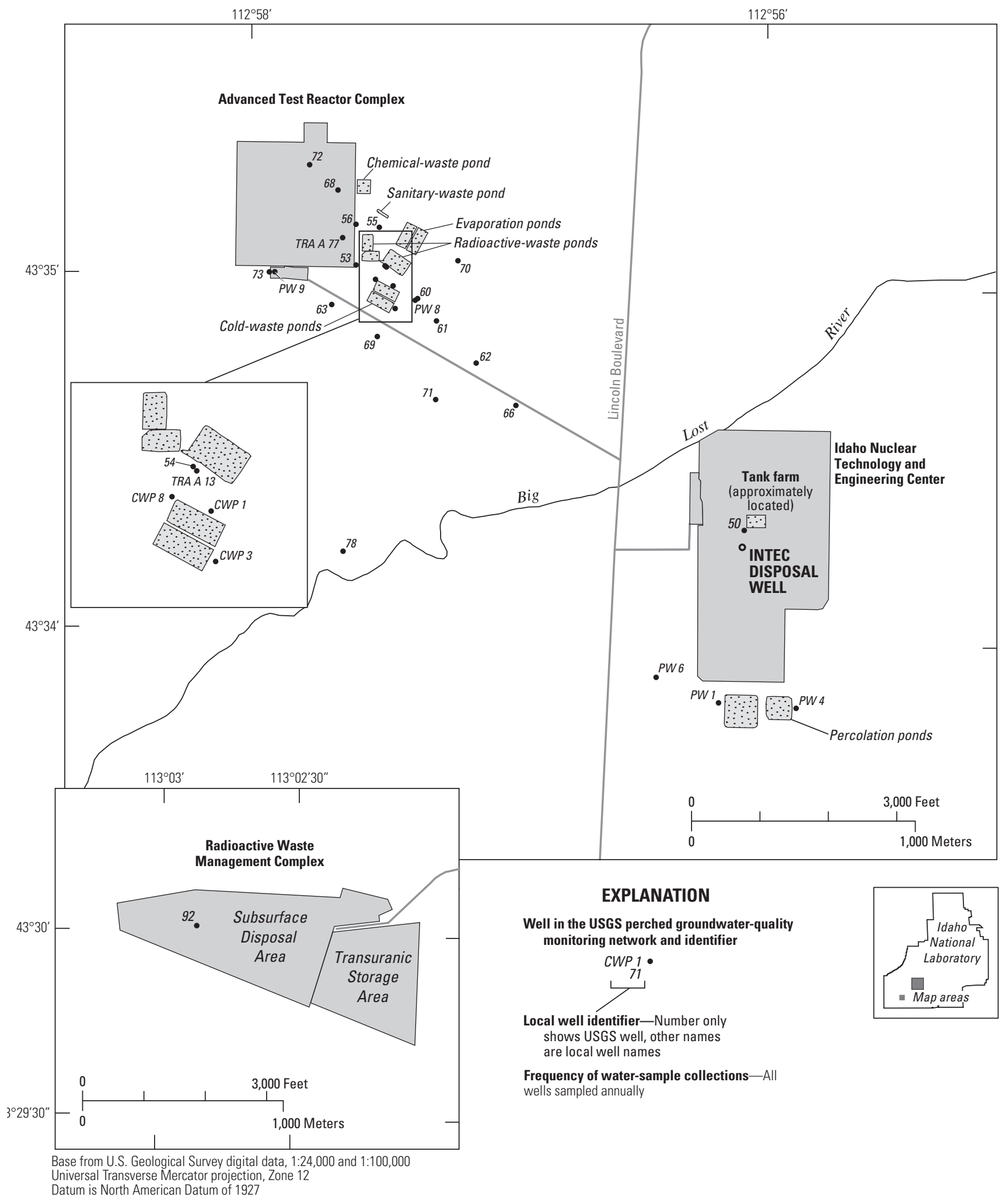

Figure 7. Location of wells in the U.S. Geological Survey perched groundwater-quality monitoring network at the Advanced Test Reactor Complex (ATRC), Idaho Nuclear Technology and Engineering Center (INTEC), and Radioactive Waste Management Complex (RWMC), Idaho National Laboratory (INL), Idaho, and frequency of water-sample collections, as of December 2008. 
Table 2. Construction of wells in the U.S. Geological Survey aquifer water-quality monitoring network and water sample-collection method, eastern Snake River Plain aquifer, Idaho National Laboratory, Idaho, as of December 2008. .

[All wells are sampled annually except those whose sample collection method is Westbay ${ }^{\mathrm{TM}}$. Westbay ${ }^{\mathrm{TM}}$ sample schedule is subject to change from year to year. Well No.: Well locations are shown in figures 5 and $\underline{6}$. Sample-collection method: Pump, sampled from pumping well (pumping rate in gallons per minute); Tap, sampled from faucet; Westbay ${ }^{\mathrm{TM}}$, sampled with multi-level thief sampler. //, hole diameter is not required for borehole volume calculations with multi-level thief samplers. Abbreviations: USGS, U.S. Geological Survey]

\begin{tabular}{|c|c|c|c|c|}
\hline Well No. & USGS site No. & \multicolumn{2}{|c|}{ Well construction } & $\begin{array}{c}\text { Sample-collection } \\
\text { method }\end{array}$ \\
\hline ANP 9 & 434856112400001 & 8 & 322 & Pump (18) \\
\hline ARBOR TEST & 433509112384801 & 10 & 790 & Pump (20) \\
\hline AREA 2 & 433223112470201 & 16 & 877 & Pump (18) \\
\hline BADGING FACILITY & 433042112535101 & 8 & 644 & Pump (35) \\
\hline CFA 1 & 433204112562001 & 16 & 639 & Pump $(1,000)$ \\
\hline CFA 2 & 433144112563501 & 16 & 681 & Pump $(1,400)$ \\
\hline CFA LF 2-10 & 433216112563301 & 6 & 716 & Pump (8.2) \\
\hline CPP 1 & 433433112560201 & 16 & 586 & Pump $(3,000)$ \\
\hline CPP 2 & 433432112560801 & 16 & 605 & Pump $(3,000)$ \\
\hline HIGHWAY 3 & 433256113002501 & 8 & 750 & Tap \\
\hline ICPP-MON-A-166 & 433300112583301 & 6 & 527 & Pump (3) \\
\hline IET 1 DISP & 435153112420501 & 12 & 324 & Pump (3) \\
\hline LEO RODGERS 1 & 432533112504901 & 20 & 720 & Pump (20) \\
\hline MIDDLE 2050A-514.9 FT & 433409112570515 & $/ /$ & 1,376 & Westbay \\
\hline MIDDLE 2050A-641.9 FT & 433409112570512 & $/ /$ & 1,376 & Westbay \\
\hline MIDDLE 2050A-790.2 FT & 433409112570509 & $/ /$ & 1,376 & Westbay \\
\hline MIDDLE 2050A-997.6 FT & 433409112570506 & $/ /$ & 1,376 & Westbay \\
\hline MIDDLE 2050A-1178.8 FT & 433409112570503 & $/ /$ & 1,376 & Westbay \\
\hline MIDDLE 2051-604.2 FT & 433217113004912 & $/ /$ & 1,175 & Westbay \\
\hline MIDDLE 2051-750.1 FT & 433217113004909 & $/ /$ & 1,175 & Westbay \\
\hline MIDDLE 2051-827.8 FT & 433217113004906 & $/ /$ & 1,175 & Westbay \\
\hline RIFLE RANGE & 433243112591101 & 5 & 620 & Pump (25) \\
\hline RWMC M1SA & 432956113030901 & 6 & 638 & Pump (3.5) \\
\hline RWMC M3S & 433008113021801 & 6 & 633 & Pump (5) \\
\hline RWMC M7S & 433023113014801 & 6 & 628 & Pump (5) \\
\hline RWMC M11S & 433058113010401 & 6 & 624 & Pump (14) \\
\hline RWMC M12S & 433118112593401 & 6 & 572 & Pump (6) \\
\hline RWMC M13S & 433037113002701 & 6 & 643 & Pump (6) \\
\hline RWMC M14S & 433052113025001 & 6 & 635 & Pump (14) \\
\hline RWMC PROD & 433002113021701 & 10,14 & 685 & Pump (200) \\
\hline SITE 4 & 433617112542001 & 8 & 495 & Pump (500) \\
\hline SITE 9 & 433123112530101 & 10 & 1,057 & Pump (30) \\
\hline SITE14 & 434334112463101 & 8,12 & 717 & Pump (36) \\
\hline
\end{tabular}


Table 2. Construction of wells in the U.S. Geological Survey aquifer water-quality monitoring network and water sample-collection method, eastern Snake River Plain aquifer, Idaho National Laboratory, Idaho, as of December 2008._Continued

[All wells are sampled annually except those whose sample collection method is Westbay ${ }^{\mathrm{TM}}$. Westbay ${ }^{\mathrm{TM}}$ sample schedule is subject to change from year to year. Well No.: Well locations are shown in figures 5 and $\underline{6}$. Sample-collection method: Pump, sampled from pumping well (pumping rate in gallons per minute); Tap, sampled from faucet; Westbay ${ }^{\mathrm{TM}}$, sampled with multi-level thief sampler. //, hole diameter is not required for borehole volume calculations with multi-level thief samplers. Abbreviations: USGS, U.S. Geological Survey]

\begin{tabular}{|c|c|c|c|c|}
\hline Well No. & USGS site No. & \multicolumn{2}{|c|}{ Well construction } & $\begin{array}{c}\text { Sample-collection } \\
\text { method }\end{array}$ \\
\hline SITE 19 & 433522112582101 & 8,10 & 860 & Pump (15) \\
\hline SPERT-1 & 433252112520301 & 14 & 653 & Pump (400) \\
\hline TRA 4 & 433521112574201 & 16,18 & 965 & Pump $(2,000)$ \\
\hline TRA DISP & 433506112572301 & 6,8 & 1,267 & Pump (25) \\
\hline USGS 1 & 432700112470801 & 5 & 636 & Pump (14) \\
\hline USGS 2 & 433320112432301 & 5 & 686 & Pump (18) \\
\hline USGS 4 & 434657112282201 & 6 & 553 & Pump (36) \\
\hline USGS 5 & 433543112493801 & 6 & 494 & Pump (3) \\
\hline USGS 9 & 432740113044501 & 6 & 632 & Pump (15) \\
\hline USGS 11 & 432336113064201 & 6 & 704 & Pump (20) \\
\hline USGS 12 & 434126112550701 & 10 & 563 & Pump (36) \\
\hline USGS 14 & 432019112563201 & 5 & 751 & Pump (18) \\
\hline USGS 15 & 434234112551701 & 10 & 610 & Pump (30) \\
\hline USGS 17 & 433937112515401 & 5,6 & 498 & Pump (15) \\
\hline USGS 18 & 434540112440901 & 4 & 329 & Pump (26) \\
\hline USGS 19 & 434426112575701 & 6 & 399 & Pump (17) \\
\hline USGS 20 & 433253112545901 & 6 & 658 & Pump (18) \\
\hline USGS 22 & 433422113031701 & 6 & 657 & Pump (5) \\
\hline USGS 23 & 434055112595901 & 5,6 & 463 & Pump (18) \\
\hline USGS 37 & 433326112564801 & 6 & 572 & Pump (8) \\
\hline USGS 38 & 433322112564301 & 4 & 612 & Pump (18) \\
\hline USGS 39 & 433343112570001 & 8 & 493 & Pump (25) \\
\hline USGS 40 & 433411112561101 & 4 & 483 & Pump (6) \\
\hline USGS 41 & 433409112561301 & 6 & 674 & Pump (15) \\
\hline USGS 42 & 433404112561301 & 6 & 678 & Pump (18) \\
\hline USGS 43 & 433415112561501 & 6 & 676 & Pump (6) \\
\hline USGS 44 & 433409112562101 & 6 & 650 & Pump (18) \\
\hline USGS 45 & 433402112561801 & 6 & 651 & Pump (18) \\
\hline USGS 46 & 433407112561501 & 6 & 651 & Pump (18) \\
\hline USGS 47 & 433407112560301 & 6 & 652 & Pump (15) \\
\hline
\end{tabular}


Table 2. Construction of wells in the U.S. Geological Survey aquifer water-quality monitoring network and water sample-collection method, eastern Snake River Plain aquifer, Idaho National Laboratory, Idaho, as of December 2008._Continued

[All wells are sampled annually except those whose sample collection method is Westbay ${ }^{\mathrm{TM}}$. Westbay ${ }^{\mathrm{TM}}$ sample schedule is subject to change from year to year. Well No.: Well locations are shown in figures 5 and $\underline{6}$. Sample-collection method: Pump, sampled from pumping well (pumping rate in gallons per minute); Tap, sampled from faucet; Westbay ${ }^{\mathrm{TM}}$, sampled with multi-level thief sampler. //, hole diameter is not required for borehole volume calculations with multi-level thief samplers. Abbreviations: USGS, U.S. Geological Survey]

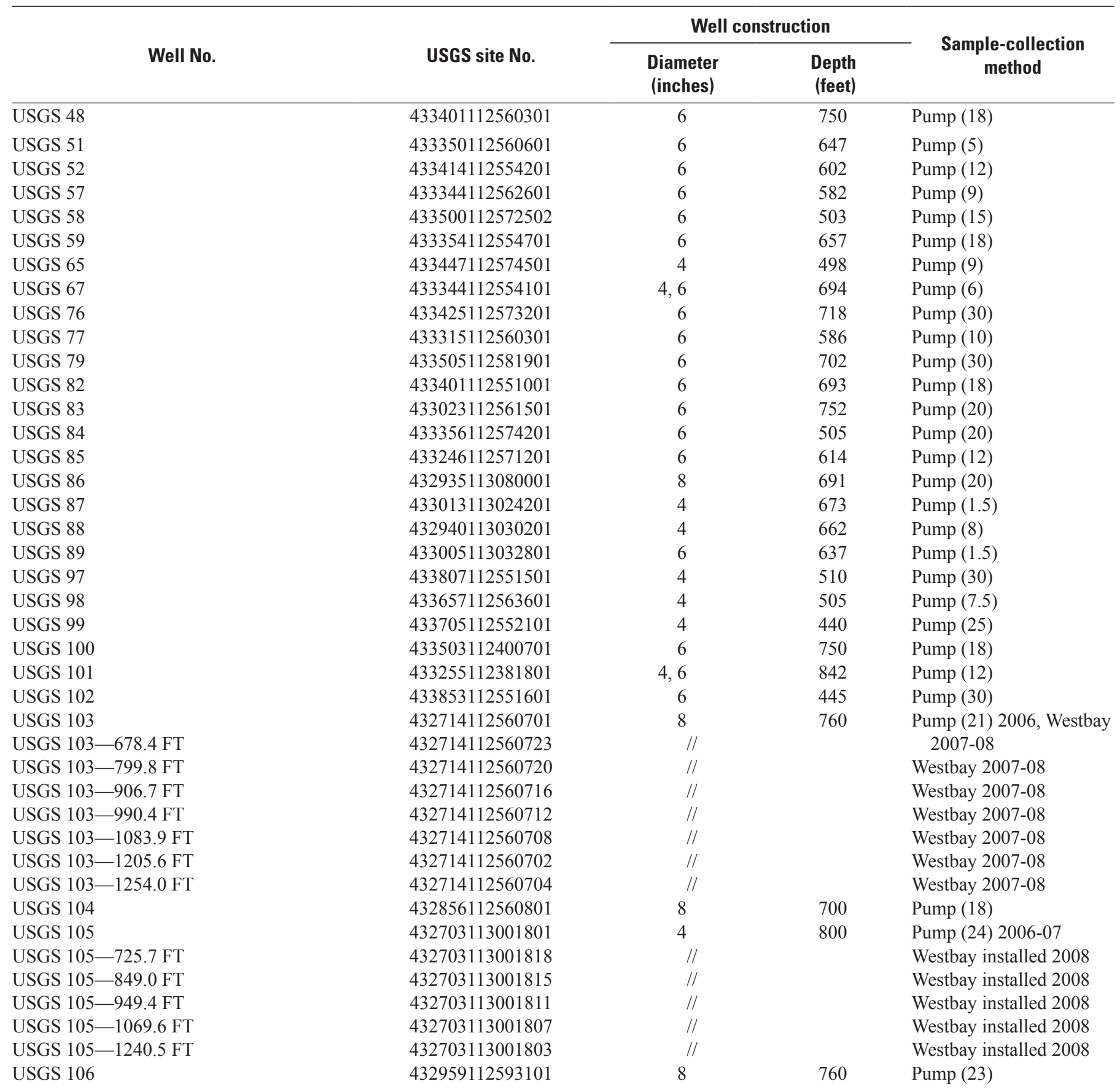


Table 2. Construction of wells in the U.S. Geological Survey aquifer water-quality monitoring network and water sample-collection method, eastern Snake River Plain aquifer, Idaho National Laboratory, Idaho, as of December 2008._Continued

[All wells are sampled annually except those whose sample collection method is Westbay ${ }^{\mathrm{TM}}$. Westbay ${ }^{\mathrm{TM}}$ sample schedule is subject to change from year to year. Well No.: Well locations are shown in figures 5 and $\underline{6}$. Sample-collection method: Pump, sampled from pumping well (pumping rate in gallons per minute); Tap, sampled from faucet; Westbay ${ }^{\mathrm{TM}}$, sampled with multi-level thief sampler. //, hole diameter is not required for borehole volume calculations with multi-level thief samplers. Abbreviations: USGS, U.S. Geological Survey]

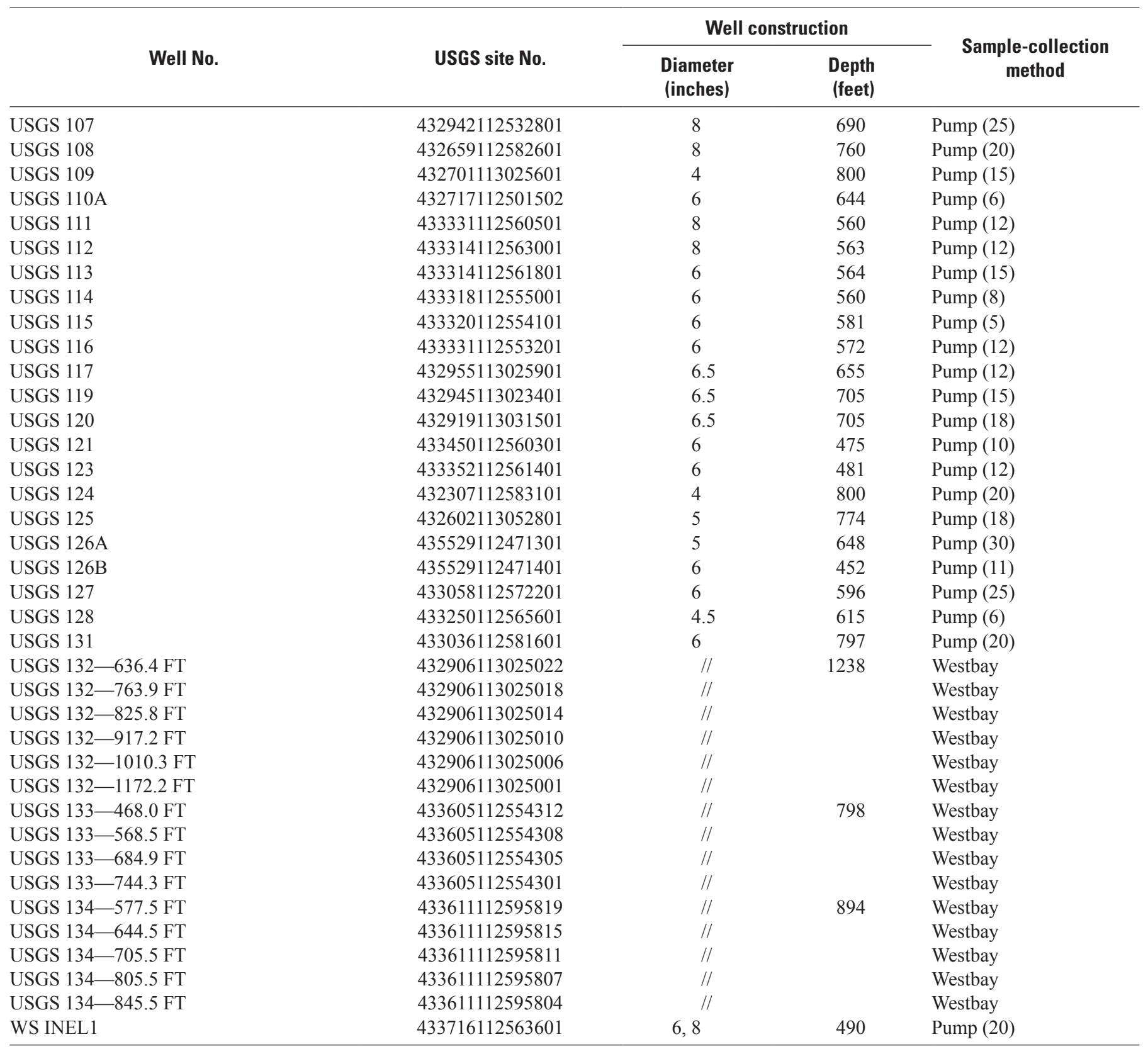


Table 3. Construction of wells in the U.S. Geological Survey perched groundwater-quality monitoring network and water samplecollection method at the Advanced Test Reactor Complex, Idaho Nuclear Technology and Engineering Center, and Radioactive Waste Management Complex, Idaho National Laboratory, Idaho, as of December 2008.

[Well No.: Well locations are shown in figure 7. Sample-collection method: Pump, sample collected with a pump (pumping rate in gallons per minute); Bail, sample collected with a bailer (sample collection depth in feet below land surface). All wells sampled annually. Abbreviation: USGS, U.S. Geological Survey]

\begin{tabular}{|c|c|c|c|c|}
\hline \multirow[b]{2}{*}{ Well No. } & \multirow[b]{2}{*}{ USGS Site no. } & \multicolumn{2}{|c|}{ Well construction } & \multirow{2}{*}{$\begin{array}{c}\text { Sample-collection } \\
\text { method }\end{array}$} \\
\hline & & $\begin{array}{l}\text { Diameter } \\
\text { (inches) }\end{array}$ & $\begin{array}{l}\text { Depth } \\
\text { (feet) }\end{array}$ & \\
\hline CWP 1 & 433459112572601 & 6 & 58 & Bail (46) \\
\hline CWP 3 & 433455112572501 & 6 & 55 & Bail (49) \\
\hline CWP 8 & 433500112573001 & 6 & 64 & Bail (58) \\
\hline PW 1 & 433349112560701 & 6 & 117 & Bail (115) \\
\hline PW 4 & 433348112554901 & 6 & 150 & Bail (126) \\
\hline PW 6 & 433353112562201 & 6 & 125 & Bail (125) \\
\hline PW 8 & 433456112572001 & 6 & 166 & Pump (6) \\
\hline PW 9 & 433500112575401 & 6 & 200 & Pump (3) \\
\hline TRAA 13 & 433502112572802 & 2 & 59 & Bail (bottom of well) \\
\hline TRA A 77 & 433507112573801 & 2 & 34 & Bail (bottom of well) \\
\hline USGS 50 & 433419112560201 & 6 & 405 & Pump $(0.5)$ \\
\hline USGS 53 & 433503112573401 & 6 & 71 & Bail \\
\hline USGS 54 & 433503112572801 & 6 & 82 & Pump (4) \\
\hline USGS 55 & 433508112573001 & 6 & 81 & Pump (1) \\
\hline USGS 56 & 433509112573501 & 6 & 80 & Pump (1) \\
\hline USGS 60 & 433456112571901 & 6 & 117 & Pump (3.5) \\
\hline USGS 61 & 433453112571601 & 4 & 123 & Pump (2) \\
\hline USGS 62 & 433446112570701 & 8 & 165 & Pump (3) \\
\hline USGS 63 & 433455112574001 & 10 & 97 & Pump (3.5) \\
\hline USGS 66 & 433436112564801 & 4 & 475 & Bail (188) \\
\hline USGS 68 & 433516112573901 & 10 & 128 & Pump (1) \\
\hline USGS 69 & 433450112573001 & 4 & 115 & Pump (4) \\
\hline USGS 70 & 433504112571001 & 8 & 100 & Pump (6) \\
\hline USGS 71 & 433439112571501 & 5 & 171 & Bail (157) \\
\hline USGS 72 & 433519112574601 & 6 & 200 & Bail (148) \\
\hline USGS 73 & 433502112575401 & 6 & 127 & Pump (1) \\
\hline USGS 78 & 433413112573501 & 7 & 204 & Bail (178) \\
\hline USGS 92 & 433000113025301 & 3.5 & 214 & Bail (212) \\
\hline
\end{tabular}




\section{Waste-Disposal Sites at the Idaho National Laboratory}

Wastewater disposal at INL facilities (fig. 1) has been the principal source of radioactive- and chemical-waste constituents in water from the Snake River Plain aquifer and in perched-groundwater zones at and near the INL. In the past, wastewater disposal sites included infiltration ponds (percolation ponds) and ditches, evaporation ponds, drain fields, and disposal wells. Solid and liquid wastes buried at the RWMC (fig. 1) also are sources of some constituents in groundwater.

Contractors at each INL facility collected radioactiveand chemical-waste-disposal data from 1976 to 1998. Historical radioactive-waste-disposal data presented in this report were obtained from the most recent radioactive-wastemanagement information report (French and others, 1999b). Chemical-waste-disposal data were obtained from the most recent nonradiological-waste-management information report (French and others, 1999a). Since 1999, no formal program has been in place to compile annual amounts of constituents discharged at each facility (Richard Kauffman, U.S. Department of Energy, oral commun., 2005); however, the INEEL Site Environmental Reports (S.M. Stoller Corporation, 2002a, 2002b, and 2002c) provide some radioactive waste disposal data for 1999-2001. The amounts and types of radioactive- and chemical-wastes discharged at the various INL facilities are not published for 1999-2008 and are not presented in this report. Highlights of the waste disposal history at INL facilities are summarized below; a more comprehensive summary of waste disposal at the INL can be found in Davis (2008).

\section{Advanced Test Reactor Complex}

Since 1952, low-level radioactive, chemical, and sanitary wastewater has been discharged to infiltration and lined evaporation ponds (fig. 3). Nonradioactive cooling-tower wastewater was discharged to radioactive-waste infiltration ponds from 1952 to 1964, to the Snake River Plain aquifer through a 1,267-ft-deep disposal well (TRA DISP, fig. 3) from 1964 until March 1982, and into two cold-waste infiltration ponds from 1982 to the present.

In 1976, the DOE contractor at the ATRC began a three-phase program to reduce radioactivity in wastewater. The first phase was from 1976 to 1980 and the second phase was from 1981 to 1987 . The contractor finished the final phase of the program in 1993. In August 1993, the radioactivewaste infiltration ponds at the ATRC were replaced with lined evaporation ponds. During 1993-98, about 515 Ci (or about $85 \mathrm{Ci} / \mathrm{yr}$ ) (French and others, 1999b) were discharged at the INL. This represents a significant decrease in discharge of radioactivity since the program began. The evaporation ponds may prevent radioactive wastewater from entering the aquifer.

During 1974-79, about 10 percent of radioactivity in wastewater discharged was attributed to tritium; most other radioactivity consisted of radionuclides with half-lives of about several weeks, as well as small amounts of strontium-90, cesium-137, and cobalt-60 (Barraclough and others, 1981). In 1980 , about 50 percent of radioactivity was attributed to tritium, and during 1981-85, about 90 percent was attributed to tritium (Pittman and others, 1988, p. 22). From 1986-2000, about 97 percent of radioactivity in wastewater discharged at the ATRC has been attributed to tritium (Davis, 2008, fig. 8). Tritium data are not available for 2001-08.

A chemical-waste infiltration pond was used for disposal of chemical wastewater from an ion-exchange system at the ATRC (fig. 3) from 1962 to 1999. The average annual discharge to this pond was about 17.5 Mgal during 1962-98. Sulfate and sodium hydrate were the predominant constituents in the chemical wastewater. During 1996-98, average annual amounts of about 210,280 lb of sulfate and 98,800 lb of sodium hydrate were discharged to the chemical-waste infiltration pond (Bartholomay and others, 2000). Additionally, about 11,100 lb of sodium ion was discharged in October 1996 (French and others, 1997). In 1999, the chemical-waste infiltration pond was closed and covered with a protective cap (S.M. Stoller Corporation, 2002a).

The TRA disposal well was used from 1964 to March 1982 to inject nonradioactive wastewater from cooling-tower operations at the ATRC into the Snake River Plain aquifer. Since March 1982, this wastewater has been discharged to two cold-waste infiltration ponds (fig. 3). The disposal well has been used as an observation well since 1982 .

Sewage effluent discharged to sanitary-waste ponds (fig. 3) at the ATRC was about $28 \mathrm{Mgal} / \mathrm{yr}$ during 1996-98 (Bartholomay and others, 2000), about $17 \mathrm{Mgal}$ in 2000, and about $52 \mathrm{Mgal}$ in 2001 (Richard Kauffman, U.S. Department of Energy, written commun., 2005). Data are unavailable for the amount of effluent discharged from 2002-08. Prior to 1990, the major constituents in the effluent were chloride and hypochlorite. Chloride and hypochlorite were not reported as part of the sewage effluent after February 1990 (Bartholomay and others, 2000). 


\section{Idaho Nuclear Technology and Engineering Center}

From 1952 to February 1984, the INTEC discharged most low-level radioactive, chemical, and sanitary wastewater into the Snake River Plain aquifer through a 600 -ft-deep disposal well. Two percolation ponds (also called infiltration ponds) were used for wastewater disposal from 1984 through August 25, 2002 (fig. 6). The first pond was completed in February 1984 and the second pond was completed in October 1985. On August 26, 2002, the existing percolation ponds were taken out of service, and wastewater was discharged to the new percolation ponds southwest of INTEC. The new percolation ponds were designed to be a rapid infiltration system, and each pond can accommodate as much as $3 \mathrm{Mgal} / \mathrm{d}$ of continuous discharge (S.M. Stoller Corporation, 2004).

Tritium accounted for most of the radioactivity in wastewater discharged to the disposal well and percolation ponds at the INTEC since 1970. During 1986-95, a total of about $559 \mathrm{Ci}$ of tritium was discharged at the INTEC, except 1989, 1993, and 1994, when tritium was not discharged. Tritium was not discharged during 1996-99 and 0.03 Ci was discharged during 2000 (Davis, 2008). Data were not available for tritium discharged during 2001-08.

During 1996-98, chloride, fluoride, nitrate, sodium, and sulfate were the predominant chemical constituents in wastewater discharged to the INTEC percolation ponds. During this period, average annual amounts of about $1,166,000 \mathrm{lb}$ of chloride; $1,070 \mathrm{lb}$ of fluoride; $86,700 \mathrm{lb}$ of nitrate; 708,000 lb of sodium, and 146,000 lb of sulfate were in wastewater discharged at the INTEC (Bartholomay and others, 2000). Data have not been compiled for predominant constituents and amounts in wastewater discharged during 1999-2008.

In 1972, about $18,100 \mathrm{Ci}$ of strontium-90 and $19,100 \mathrm{Ci}$ of cesium-137 were released to soil at the INTEC Tank Farm (fig. 7) (Cahn and others, 2006). In 1972, during a failed transfer of waste between two underground storage tanks, about 18,600 gal of sodium-bearing waste was leaked at an INTEC Tank Farm site. This accounts for about 88 percent (approximately 15,900 Ci) of the source of strontium-90 to groundwater at the Tank Farm. Three other locations at the Tank Farm are the source of the remaining 12 percent of strontium-90 (Cahn and others, 2006).

\section{Radioactive Waste Management Complex}

Solid and liquid radioactive and chemical wastes have been buried in trenches and pits at the Subsurface Disposal Area (SDA) at the RWMC (fig. 3) since 1952.
These include transuranic wastes, other radiochemical and inorganic chemical constituents, and organic compounds. The transuranic wastes were buried in trenches until 1970, and stored above ground at the RWMC after 1970. Only low-level mixed waste has been buried at the RWMC since 1970.

Before 1970, little or no sediment was retained between the excavation bottoms and the underlying basalt. Since 1970, a layer of sediment has been retained in excavations to inhibit downward migration of waste constituents.

About 17,100 Ci of plutonium-238, 64,900 Ci of plutonium-239, 17,100 Ci of plutonium-240, and 183,000 Ci of americium-241 were buried in the SDA during 1952-99 (Holdren and others, 2002, table 4-1). An estimated 88,400 gal of organic waste was buried before 1970 (Mann and Knobel, 1987, p. 1). These buried wastes included about 24,400 gal of carbon tetrachloride; 39,000 gal of lubricating oil; and about 25,000 gal of other organic compounds, including trichloroethane, trichloroethylene, perchloroethylene, toluene, and benzene.

\section{Test Area North}

From 1953 to 1972, low-level radioactive, chemical, and sanitary wastewater was discharged at TAN (fig. 1) into the Snake River Plain aquifer through a 310-ft-deep disposal well (TAN Disposal Well, fig. 5). In 1972, the disposal well was replaced by a 35-acre infiltration pond. Records are not available to indicate the amount of radioactivity in wastewater discharged at TAN before 1959. During 1959-93, about $61 \mathrm{Ci}$ of radioactivity in wastewater were discharged to the disposal well and infiltration pond. Radioactive wastewater has not been discharged since 1993 (Bartholomay and others, 2000). Information is not available about constituents in wastewater discharged since 1998.

Chemical wastewater containing predominantly chloride and sodium was discharged to the infiltration pond at the Technical Support Facility (TSF) near TAN during 1996-98, with average annual amounts of 6,900 and 4,500 lb, respectively. The average annual amount of all other chemical constituents in the wastewater was about $760 \mathrm{lb}$ (Bartholomay and others, 2000). Data were not available for total amounts of individual constituents disposed in wastewater for 1999-2007. A closure plan for the pond was submitted to the Idaho Department of Environmental Quality in November 2007, and wastewater discharge to the pond ceased on November 29, 2007. All activities proposed in the plan were completed by February 2008 (S.M. Stoller Corporation, 2009). 


\section{Central Facilities Area}

About $65 \mathrm{Ci}$ of radioactivity in about 1,500 Mgal of wastewater were discharged to the sewage-plant tile drain field at the CFA (fig. 1) during 1952-93. Most radioactive wastes discharged to this drain field were from aquifer water pumped from well CFA 1 (fig. 5), which obtains water from within the INTEC contaminant plume in the Snake River Plain aquifer. Most radioactivity in wastewater discharged at the CFA was attributed to tritium. During 1993-98, no radioactivity was recorded in wastewater discharged at the CFA (Bartholomay and others, 2000). Data were not available for radioactivity in wastewater at the CFA for 1999-2008.

Chloride and sodium were the predominant chemical constituents in wastewater at the CFA during 1996-98. Average annual amounts of about 7,800 lb of chloride and 5,300 lb of sodium were discharged during 1996-98. The average annual amount of all other constituents in the wastewater was about $6,300 \mathrm{lb}$; about $5,400 \mathrm{lb}$ was from disposal of janitorial supplies (Bartholomay and others, 2000). Data were not available for total amounts of individual constituents disposed in wastewater for 1999-2008.

\section{Hydrologic Conditions}

The Snake River Plain aquifer is one of the most productive aquifers in the United States (U.S. Geological Survey, 1985, p. 193). The aquifer consists of a thick sequence of basalts and sedimentary interbeds filling a large, arcuate, structural basin in southeastern Idaho (fig. 1). Recharge to the Snake River Plain aquifer is primarily from infiltration of applied irrigation water, infiltration of streamflow, groundwater inflow from adjoining mountain drainage basins, and infiltration of precipitation.

\section{Surface Water}

The Big Lost River drains more than $1,400 \mathrm{mi}^{2}$ of mountainous area that includes parts of the Lost River Range and the Pioneer Mountains west of the INL (fig. 1). Flow in the Big Lost River infiltrates to the Snake River Plain aquifer along the river channel and at sinks and playas at its terminus. To avoid flooding at the INL facilities, excess runoff has been diverted since 1965 to spreading areas in the southwestern part of the INL (Bennett, 1990, p. 15), where much of the water rapidly infiltrates to the aquifer. Other surface drainages that provide recharge to the Snake River Plain aquifer at the INL include Birch Creek, Little Lost River, and Camas Creek (fig. 1).
The average streamflow recorded at USGS gaging station 13127000, Big Lost River below Mackay Reservoir near Mackay, ID (fig. 1) for complete water years (October 1September 30) 1905-2008 was 219,400 acre-ft/yr (U.S. Geological Survey, 2006, 2007, 2008) (fig. 8). Streamflow at gaging stations at and downstream of gaging station 13127000 (fig. 1) for water years 2006-08 are shown in table 4 and figure 8.

Recharge to the Snake River Plain aquifer downstream of Arco, Idaho, is substantial during wet years because of streamflow infiltration from the Big Lost River channel, diversion areas, sinks, and playas. For example, infiltration losses at various discharges measured during 1951-85 ranged from $1\left(\mathrm{ft}^{3} / \mathrm{s}\right) / \mathrm{mi}$ in the river channel to $28\left(\mathrm{ft}^{3} / \mathrm{s}\right) / \mathrm{mi}$ in the sinks (Bennett, 1990, p. 24-26). Bennett considered streamflow losses to evapotranspiration minor as compared to infiltration losses. However, infiltration can be zero in years when there is little or no flow in the Big Lost River channel as was the case during 2002-04 (Davis, 2008), and 2008 at or downstream of gaging station 13132500 (table 4).

Table 4. Average annual streamflow at U.S. Geological Survey streamflow-gaging stations along the Big Lost River, Idaho, water years 2006-08.

[Gaging station: Station locations are shown in figure 1. Streamflow: Data are from U.S. Geological Survey (USGS), 2006, 2007, and 2008. Abbreviations: INL, Idaho National Laboratory; WY, water year]

\begin{tabular}{|c|c|c|c|}
\hline \multirow{2}{*}{$\begin{array}{l}\text { USGS streamflow- } \\
\text { gaging station }\end{array}$} & \multicolumn{3}{|c|}{$\begin{array}{l}\text { Streamflow } \\
\text { (in acre-feet) }\end{array}$} \\
\hline & WY 2006 & WY 2007 & WY 2008 \\
\hline $\begin{array}{l}13127000 \text { Big Lost River below } \\
\text { Mackay Reservoir, near Mackay, } \\
\text { Idaho }\end{array}$ & 278,600 & 153,600 & 158,100 \\
\hline $\begin{array}{l}13132500 \text { Big Lost River near } \\
\text { Arco, Idaho }\end{array}$ & 35,810 & 728 & 0 \\
\hline $\begin{array}{l}13132513 \text { INL diversion at head, } \\
\text { near Arco, Idaho }\end{array}$ & 3,840 & 0 & 0 \\
\hline $\begin{array}{l}13132520 \text { Big Lost River below the } \\
\text { INL Diversion, near Arco, Idaho }\end{array}$ & 24,030 & 0 & 0 \\
\hline $\begin{array}{l}13132565 \text { Big Lost River above } \\
\text { Big Lost River Sinks, near Howe, } \\
\text { Idaho }\end{array}$ & 12,840 & 0 & 0 \\
\hline
\end{tabular}



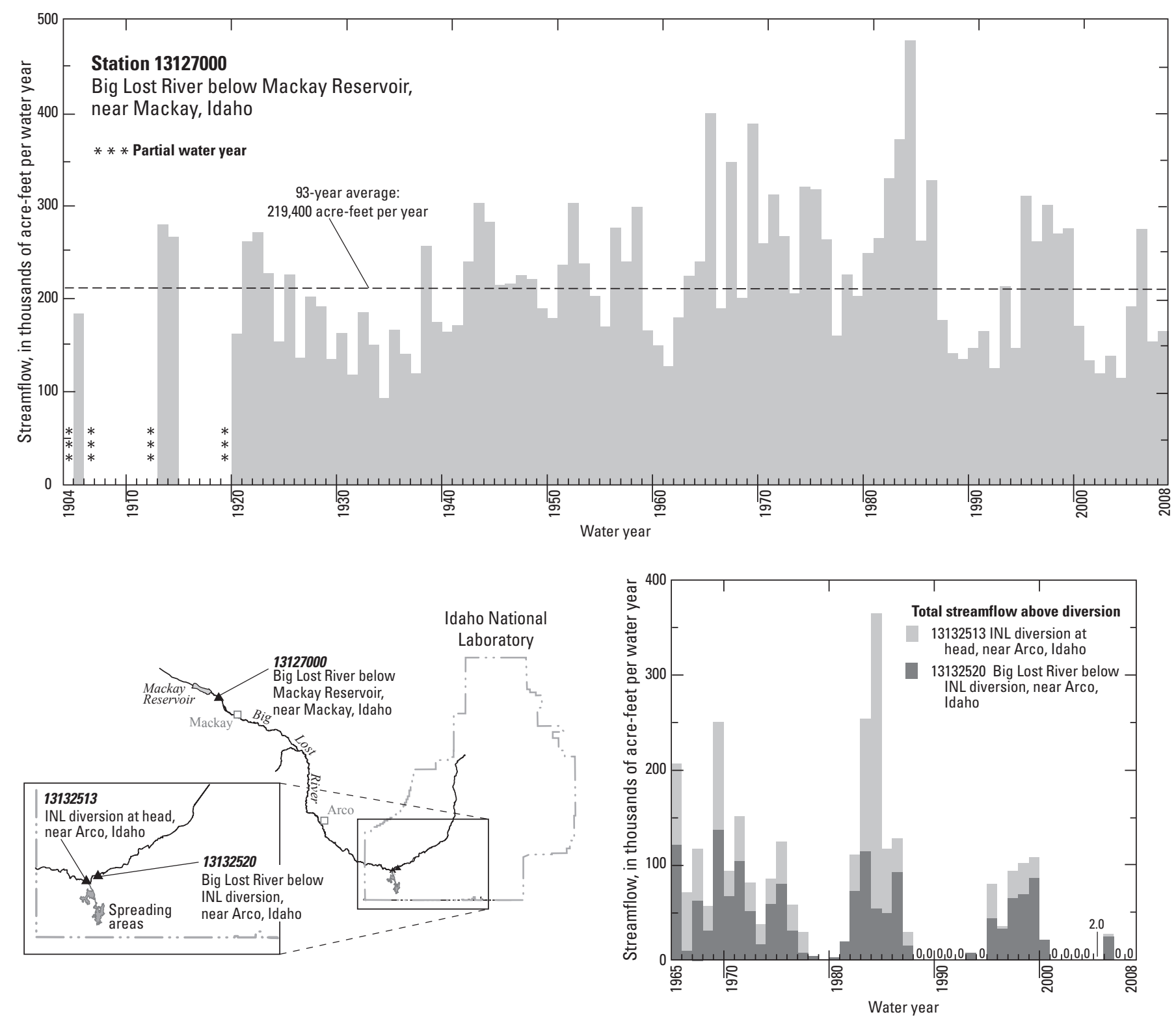

Figure 8. Streamflow at gaging stations along the Big Lost River: Big Lost River below Mackay Reservoir, water years 1905, 1913-14, and 1920-2008; Big Lost River below the Idaho National Laboratory (INL) diversion, near Arco; and INL diversion at head, near Arco, Idaho, water years 1965-2008.

\section{Groundwater}

Water in the Snake River Plain aquifer primarily moves through interflow and fracture zones in the basalt. A large proportion of groundwater moves through the upper 200 to $800 \mathrm{ft}$ of basaltic rocks (Mann, 1986, p. 21). Ackerman (1991, p. 30) and Bartholomay and others (2000, p. 15) reported a range of transmissivity of basalt in the upper part of the aquifer of 1.1 to $760,000 \mathrm{ft}^{2} / \mathrm{d}$. Anderson and others (1999) reported a range of hydraulic conductivity at the INL of 0.01 to $32,000 \mathrm{ft} / \mathrm{d}$. The hydraulic conductivity of rocks underlying the aquifer is from 0.002 to $0.03 \mathrm{ft} / \mathrm{d}$ (Mann, 1986, p. 21). The effective base of the Snake River Plain aquifer probably ranges from about 815 to $1,710 \mathrm{ft}$ below land surface in the western half of the INL based on data from wells that penetrate the base of the aquifer (Anderson and others, 1996, table 3). Wells in the eastern half of the INL do not penetrate the base of the aquifer, so the effective base of the aquifer cannot be estimated in that area. 
Depth to water in wells completed in the Snake River Plain aquifer ranges from about $200 \mathrm{ft}$ in the northern part of the INL to more than $900 \mathrm{ft}$ in the southeastern part. During March-May 2008, the altitude of the water table was about $4,560 \mathrm{ft}$ in the northern part of the INL (fig. 9) and about 4,410 to $4,420 \mathrm{ft}$ in the southwestern part. Water flowed south and southwestward beneath the INL (fig. 9) at an average hydraulic gradient of about $4 \mathrm{ft} / \mathrm{mi}$.

Water levels in wells generally remained constant or declined in the INL area from March-May 2005 to March-May 2008 (fig. 10). In the southwestern part of the INL, most water levels were unchanged from the March-May 2005 reporting period or rose slightly (fig. 10). In the central part of the INL, water levels declined about 1-3 ft, and in the northern part of the INL, water levels declined as much as $9 \mathrm{ft}$. Water levels monitored in wells USGS 12, 17, and 23 (fig. 2), and 20 (fig. 3) show long-term water-level changes in the Snake River Plain aquifer in the central part of the INL in response to infiltration of streamflow (fig. 11). Long-term water-level fluctuations have ranged from about $18 \mathrm{ft}$ in well USGS 20 to about $36 \mathrm{ft}$ in well USGS 12. Water levels in these wells rose during 2006, but declined overall from 2007 to 2008 mostly because of lack of streamflow infiltration from the Big Lost River.

Groundwater moves southwestward from the INL and eventually discharges to springs along the Snake River near Twin Falls, Idaho, about $100 \mathrm{mi}$ southwest of the INL. Discharge from the springs estimated by methods given by Kjelstrom (1995) was about 3.64 million acre-ft/yr for water year 2008 (Tom Brennan, U.S. Geological Survey, written commun., 2009). Historically, the discharge to these springs has ranged from 2.97 million acre-ft/yr in 1904 to 4.94 million acre-ft/yr in 1951 (Daniel J. Ackerman, U.S. Geological Survey, written commun., 2007).

\section{Perched Ground water}

Disposal of wastewater to infiltration ponds and infiltration of surface water at waste-burial sites resulted in formation of perched groundwater in basalts and in sedimentary interbeds that overlie the Snake River Plain aquifer. Perched groundwater has formed in a complex sequence of basalt flow and sedimentary interbeds beneath the ATRC, the INTEC, and the RWMC. Anderson and Lewis (1989) and Anderson (1991) correlated geophysical logs to describe the stratigraphic sequences in which perched groundwater has formed. Although the subsurface stratigraphy, geohydrologic characteristics, and waste disposal practices at each of these areas differs, the features controlling the formation of perched groundwater at these sites are similar (Cecil and others, 1991). Sedimentary interbeds in the subsurface may have smaller vertical hydraulic conductivities than overlying basalt flows, and alteration between basalt flows may contribute to reduced vertical hydraulic conductivity in the interflow rubble zones. Dense, unfractured basalt flows may have a decreased vertical hydraulic conductivity and inhibit downward flow, and sedimentary or chemical infilling of fractures in basalt may reduce vertical hydraulic conductivity by limiting the interconnectivity of fractures reducing the water transmitting capability of the basalts (Cecil and others, 1991). Any combination of these factors may disrupt the downward vertical movement of water and contribute to the formation of perched groundwater zones.

At the ATRC, deep and shallow perched groundwater zones have formed in response to disposal of wastewater to infiltration ponds (Tucker and Orr, 1998). South of the INTEC, perched groundwater zones also have formed in response to wastewater disposal to two infiltration ponds. Perched groundwater also has been found in other areas at the INTEC and may be attributed to leaking pipelines, leach fields, damaged casing in the upper part of the disposal well, other infiltration ponds, or landscape irrigation (Tucker and Orr, 1998). Perched groundwater beneath the RWMC formed from infiltration of snowmelt and rain and recharge from the Big Lost River and INL spreading areas. This perched groundwater contains constituents leached from buried radioactive and organic-chemical wastes. Perched groundwater beneath wastewater infiltration ponds and buried waste is an integral part of the pathway for waste-constituent migration to the eastern Snake River Plain aquifer. The extent of perched groundwater is affected by the waste-disposal practices.

During March-May 2008, water levels in perched groundwater wells around the ATRC declined since the March-May 2005 reporting period. Water-level declines ranged from about $0.7 \mathrm{ft}$ in well CWP 8 to about $21.5 \mathrm{ft}$ in well USGS 54 (fig. 4). Well CWP 8 is completed in shallow perched groundwater and the water level in this well is influenced by discharge to the cold waste ponds. Well USGS 54 is completed in deep perched groundwater and the water level probably is influenced by the cold waste ponds, radioactive waste ponds, and chemical waste ponds. Waterlevel declines may be attributed to lack of infiltration of water in the Big Lost River channel during 2007-08 (table 4), an overall decrease in recharge at the INL during 2006-08, or a decrease in wastewater discharge to the different ponds. 


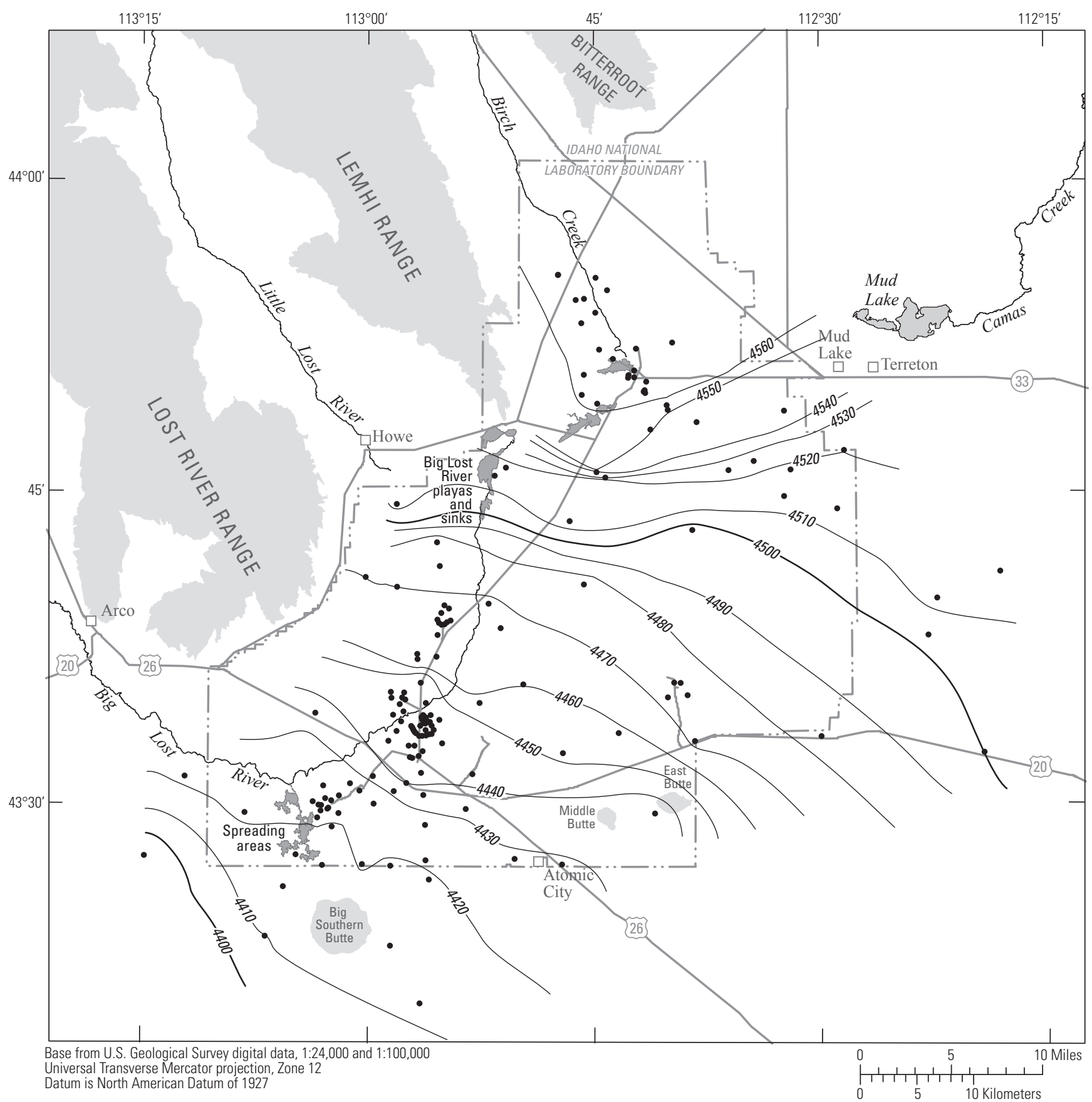

EXPLANATION

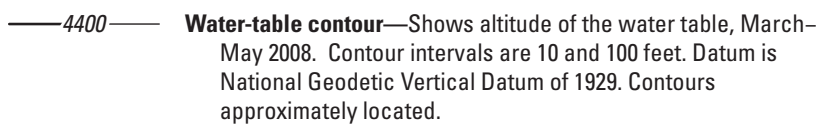

Well in the USGS water-level monitoring network at which water level was measured

Figure 9. Altitude of the water table in the Snake River Plain aquifer at and near the Idaho National Laboratory, Idaho, March-May 2008. 


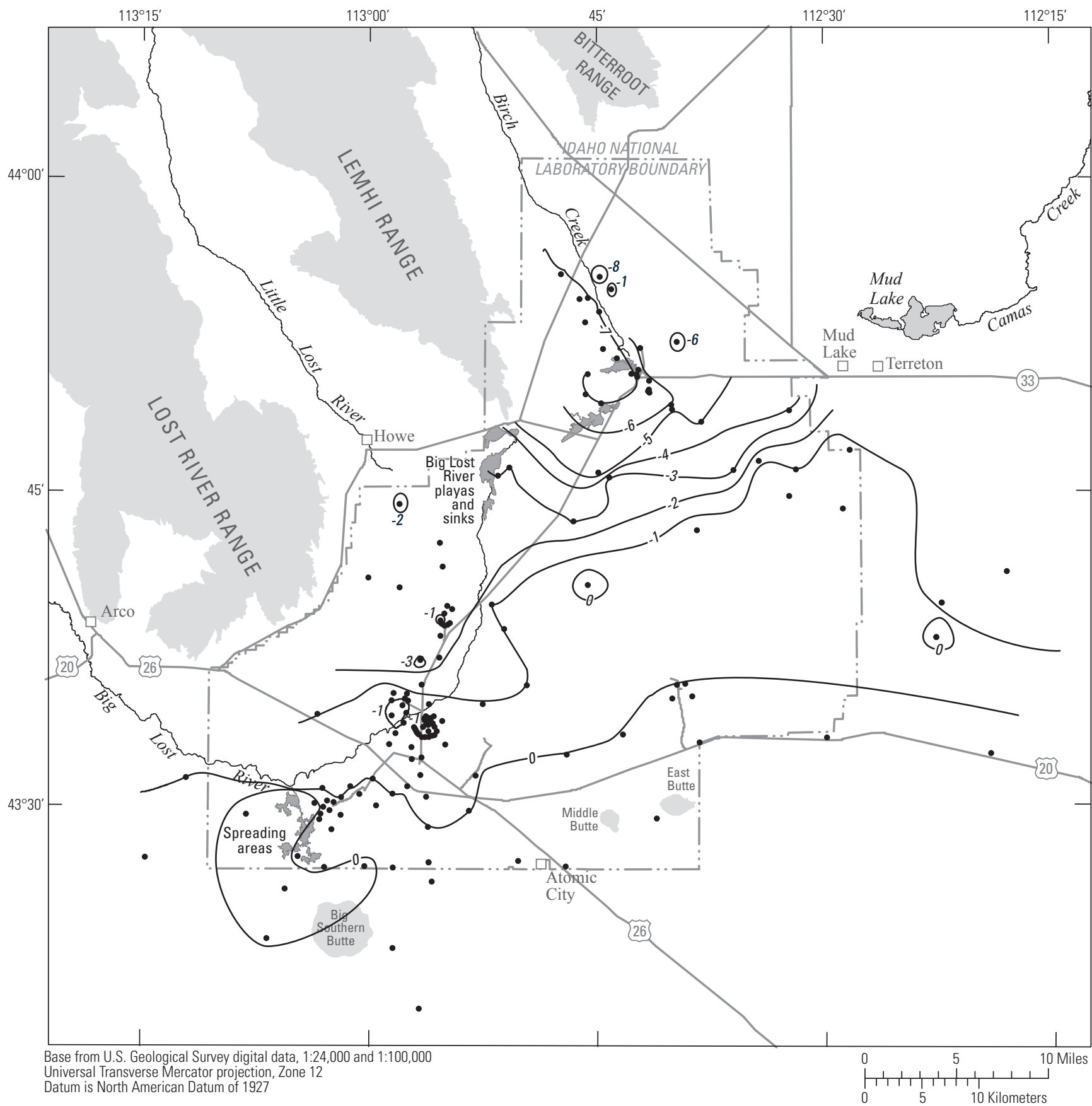

\section{EXPLANATION}

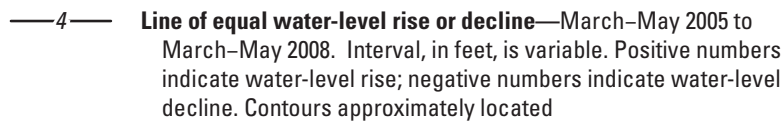

- Well in the USGS water-level monitoring network at which water level was measured

Figure 10. Generalized rise or decline in groundwater levels in the Snake River Plain aquifer at and near Idaho National Laboratory (INL), Idaho, March-May 2005 to March-May 2008. 

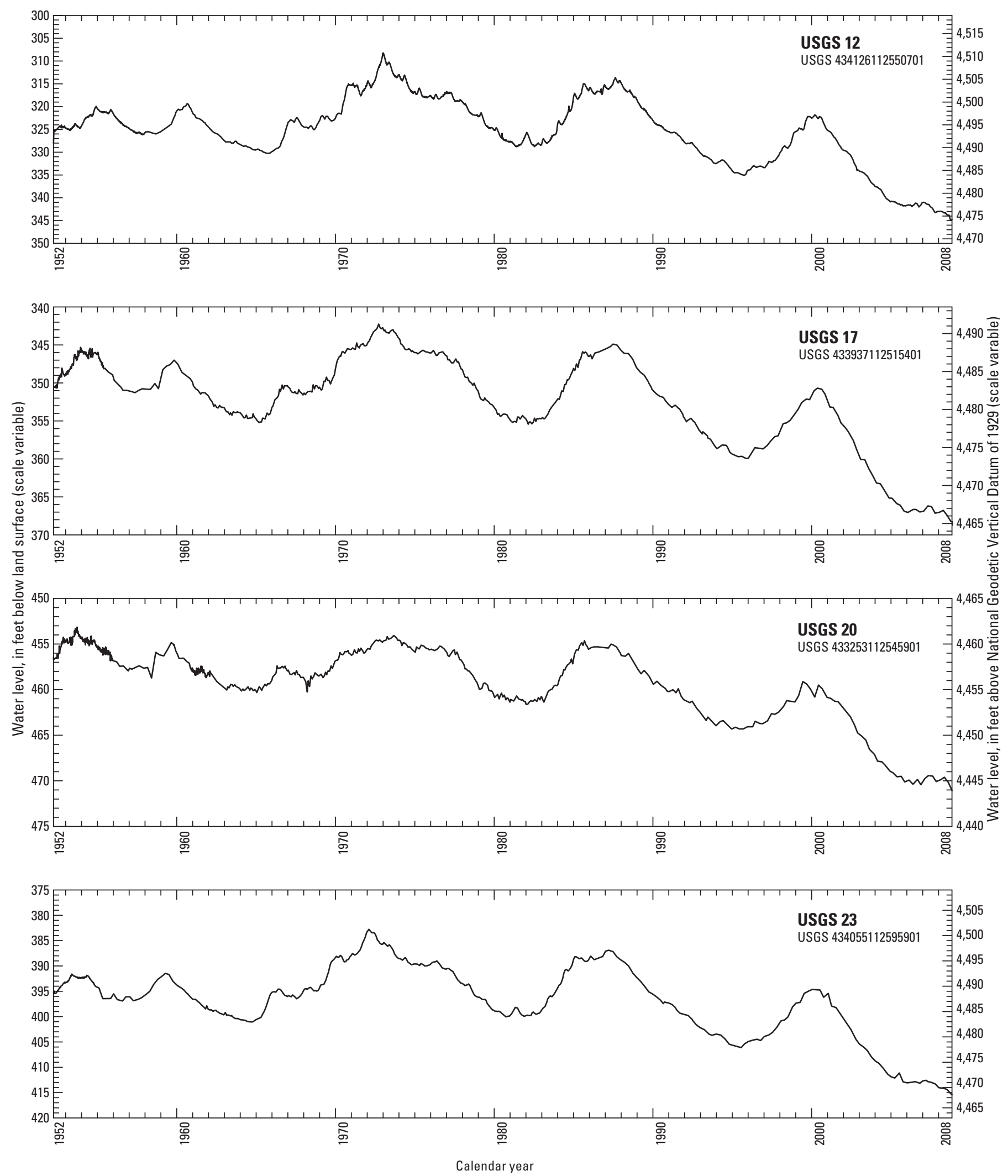

Figure 11. Water levels in four wells (USGS 12, 17, 20, 23) in the central part of the Idaho National Laboratory, Idaho, 1952-2008. 


\section{Methods and Quality Assurance of Water Sample Analyses}

Water samples were analyzed for radiochemical constituents at the DOE Radiological and Environmental Sciences Laboratory (RESL) at the INL and for chemical constituents at the USGS National Water Quality Laboratory (NWQL) in Lakewood, Colorado. Until 2008, water samples analyzed by the RESL reported an uncertainty of $2 s$, where $\boldsymbol{s}$ is the sample standard deviation, and were entered into the USGS National Water Information System (NWIS) database with this uncertainty. In 2008, RESL began reporting the uncertainty as $1 s$, and data are now entered into NWIS with the $1 s$ uncertainty. Analytical uncertainties in this report are reported as $1 \boldsymbol{s}$ for consistency with conventions used in previous USGS reports.

Methods used to sample and analyze for selected constituents generally follow the guidelines established by the USGS (Goerlitz and Brown, 1972; Stevens and others, 1975; Wood, 1976; Claassen, 1982; Wershaw and others, 1987; Fishman and Friedman, 1989; Faires, 1993; Fishman, 1993; and Wilde and others, 1998). Water samples were collected according to a quality-assurance plan for waterquality activities conducted by personnel at the USGS INL Project Office. The plan was finalized in June 1989, revised in March 1992, in 1996 (Mann, 1996), in 2003 (Bartholomay and others, 2003), and in 2008 (Knobel and others, 2008). The plan is available for inspection at the USGS INL Project Office.

Water samples collected for dissolved constituent analysis are filtered through a 0.45 -micron membrane filter. About 10 percent of water samples collected generally are for quality assurance. Quality-assurance water samples collected by the USGS INL Project Office include equipment blanks, splits, and replicates.

Water samples were collected from six wells equipped with dedicated multi-level Westbay ${ }^{\mathrm{TM}}$ packer sampling systems using pre-cleaned stainless-steel thief sampling bottles which were lowered to the zone to be sampled, connected to the sampling port, and filled with formation water. The stainless-steel bottles were then raised to the surface and emptied into a pre-cleaned container; the water was then processed to fill appropriate bottles for analyses. Field measurements also were taken from the pre-cleaned container (Bartholomay and Twining, 2010).

Field processing of water samples differed depending on the constituents for which analyses were requested. Water samples analyzed by the NWQL were placed in containers and preserved in accordance with laboratory requirements specified by Timme (1995) and Knobel and others (2008, appendix A). Containers and preservatives used for this study were supplied by the NWQL and were processed using a rigorous quality-control procedure (Pritt, 1989, p. 75) to minimize sample contamination. Water samples requiring filtration consisted of filtering the water through a disposable $0.45-\mu \mathrm{m}$ filter cartridge that had been pre-rinsed with at least $1 \mathrm{~L}$ of deionized water. Water samples analyzed by the RESL were placed in containers and were preserved in accordance with laboratory requirements specified by Bodnar and Percival (1982) and Knobel and others (2008, appendix A).

Comparative studies to determine agreement between analytical results for individual water-sample pairs by laboratories involved in the INL Project Office quality-assurance program were summarized by Wegner (1989), and Williams (1996, 1997). Additional qualityassurance studies by USGS INL Project Office personnel include:

- An evaluation of field sampling and preservation methods for strontium-90 (Cecil and others, 1989);

- A study comparing pump types used for sampling VOCs (Knobel and Mann, 1993);

- An analysis of tritium and strontium-90 concentrations in water from wells after purging different borehole volumes (Bartholomay, 1993);

- An analysis of effects of various preservation types on nutrient concentrations (Bartholomay and Williams, 1996);

- An analysis of two analytical methods to determine gross alpha- and beta-particle activity (Bartholomay and others, 1999);

- An evaluation of well-purging effects on water-quality results (Knobel, 2006);

- An evaluation of the 2006-08 Westbay ${ }^{\mathrm{TM}}$ quality assurance data is given in Bartholomay and Twining (2010).

\section{Guidelines for Interpreting Results of Radiochemical Analyses}

Concentrations of radionuclides are reported with an estimated sample standard deviation, $\boldsymbol{s}$, which is obtained by propagating sources of analytical uncertainty in measurements. The following guidelines for interpreting analytical results are based on an extension of a method proposed by Currie (1984).

In the analysis for a particular radionuclide, laboratory measurements are made on a target sample and a prepared blank. Instrument signals for the sample and the blank vary randomly. Therefore, it is essential to distinguish between two key aspects of the problem of detection: (1) the instrument signal for the sample must be greater than the signal 
observed for the blank before a decision can be made that the radionuclide was detected, and (2) an estimation must be made of the minimum radionuclide concentration that will yield a sufficiently large observed signal before a correct decision can be made for detection or nondetection of the radionuclide. The first aspect of the problem is a qualitative decision based on an observed signal and a definite criterion for detection. The second aspect of the problem is an estimation of the detection capabilities of a given measurement process.

In the laboratory, instrument signals must exceed a critical level of $1.6 s$, where $s$ is the sample standard deviation, before the qualitative decision can be made as to whether the radionuclide was detected. At 1.6s, there is about a 95-percent probability that the correct conclusion-not detected-will be made. Given a large number of water samples, as many as 5 percent of the water samples with measured concentrations greater than or equal to $1.6 \mathrm{~s}$, concluded as detected, might not contain the radionuclide. These measurements are referred to as false positives and are errors of the first kind in hypothesis testing.

Once the critical level of $1.6 \mathrm{~s}$ has been defined, the minimum detectable concentration may be determined. Concentrations that equal $3 s$ represent a measurement at the minimum detectable concentration. For actual concentrations equal to or greater than $3 s$, there is a 95 percent or higher probability that the radionuclide was detected in a water sample. In a large number of water samples, the conclusionnot detected - will be made in 5 percent of the water samples that contain actual concentrations at the minimum detectable concentration of $3 \mathrm{~s}$. These measurements are referred to as false negatives and are errors of the second kind in hypothesis testing.

Actual radionuclide concentrations between $1.6 \mathrm{~s}$ and $3 s$ have larger errors of the second kind. That is, there is a larger-than-5-percent probability of false negative results for water samples with actual concentrations between $1.6 \mathrm{~s}$ and $3 \boldsymbol{s}$. Although the radionuclide might have been detected, such detection may not be considered reliable; at $1.6 \mathrm{~s}$, the probability of a false negative is about 50 percent.

The critical level and minimum detectable concentrations are based on counting statistics alone and do not include systematic or random errors inherent in laboratory procedures. The values $1.6 s$ and $3 s$ vary slightly with background or blank counts, with the number of gross counts for individual analyses, and for different radionuclides.

In this report, radionuclide concentrations less than $3 \mathrm{~s}$ are considered to be less than a "reporting level." The critical level, minimum detectable concentration, and reporting level aid the reader to interpret analytical results and do not represent absolute concentrations of radioactivity, which may or may not have been detected. Analytical uncertainties in this report are reported as $1 s$ for consistency with conventions used in previous reports.

\section{Guidelines for Interpreting Results of Chemical Analyses}

Historically, the NWQL has used a minimum reporting level (MRL) to report nondetected concentrations or concentrations less than the MRL. The MRL for chemical constituents is the lowest measured concentration of a constituent (the "less than" value reported by NWQL) that may be reliably reported using a given analytical method (Timme, 1995). However, NWQL determined that establishment of MRLs often was inconsistent, undefined, undocumented, and subjective (Childress and others, 1999). Therefore, in 1998, NWQL implemented new reporting procedures for some analytical methods based on long-term method detection levels. Childress and others (1999, p. 16) explained the new reporting procedures used by NWQL as:

The USGS National Water Quality Laboratory collects quality-control data on a continuing basis to evaluate selected analytical methods to determine long-term method detection levels (LT-MDLs) and laboratory reporting levels (LRLs). These values are re-evaluated each year on the basis of the most recent quality control data and, consequently, may change from year to year.

This reporting procedure limits the occurrence of false positive error. The chance of falsely reporting a concentration greater than the LT-MDL for a water sample in which the analyte is not present is 1 percent or less. Application of the LRL limits the occurrence of false negative error. The chance of falsely reporting a non-detection for a water sample in which the analyte is present at a concentration equal to or greater than the LRL is 1 percent or less.

Accordingly, concentrations are reported as less than $(<)$ the LRL for water samples in which the analyte was either not detected or did not pass identification. Analytes that are detected at concentrations between the LT-MDL and LRL and that pass identification criteria are estimated. Estimated concentrations will be noted with a remark code of "E." These data should be used with the understanding that their uncertainty is greater than that of data reported without the "E" remark code.

New LRLs were established for some analytical methods during 2006-08. In this report, concentrations determined using these methods are reported as greater than the LRL; concentrations determined using other methods are reported as greater than the MRL. Estimated concentrations less than the LRLs are treated as nondetected concentrations for consistency with treatment in previous publications, and because an estimated concentration is considered a "qualitatively detected analyte" (Childress and others, 1999, p. 7). 


\section{Selected Radiochemical and Chemical Constituents and Physical Properties of Water in the Snake River Plain Aquifer}

\begin{abstract}
Contaminant plumes of radiochemical and chemical constituents in the Snake River Plain aquifer at the INL are attributed to waste-disposal practices. Areal distribution of the plumes was interpreted from analyses of water samples collected from a three-dimensional flow system. Concentrations of these constituents represent water samples collected during April or October 2008 from wells completed at various depths in the aquifer and with differing well completions. For example, single and multiple screened intervals and open boreholes. No attempt was made to determine the vertical extent and distribution of these plumes. However, beginning in 2006, water samples were collected from six wells with dedicated multi-level Westbay ${ }^{\mathrm{TM}}$ packer sampling systems that may allow for the description of the vertical distribution of selected constituents in the aquifer. Radiochemical and chemical constituents analyzed for in groundwater samples collected from wells at the INL during 2006-08 include tritium, strontium-90, cesium-137, plutonium-238, plutonium-239, -240 (undivided), americium-241, gross alpha- and beta-particle radioactivity, chromium and other trace elements, sodium, chloride, sulfate, nitrate (as N), fluoride, VOCs, and total organic carbon. Physical properties of water measured during sampling events included specific conductance, temperature, and $\mathrm{pH}$.
\end{abstract}

\section{Tritium}

A tritium plume has developed in the Snake River Plain aquifer from discharge of wastewater at the INL since the 1950s. Tritium has a half-life of 12.3 years (Walker and others, 1989, p. 20). The MCL for tritium is $20,000 \mathrm{pCi} / \mathrm{L}$ (U.S. Environmental Protection Agency, 2001). The primary sources of tritium in the aquifer have been the injection of wastewater through the disposal well at INTEC and the discharge of wastewater to the percolation ponds at the INTEC (fig. 4). Routine use of the disposal well at the INTEC ended in February 1984; subsequently, radioactive wastewater has been discharged to the percolation ponds. About 31,620 Ci of tritium in wastewater was discharged to the well and percolation ponds from 1952 to 1995 (Bartholomay and others, 2000). During 1996-99, tritium was not discharged to the ponds at the INTEC; during 2000, $0.03 \mathrm{Ci}$ of tritium was discharged (S.M. Stoller Corporation, 2002a, 2002b). Data have not been compiled for the total amount of tritium in wastewater discharged at the INTEC during 2001-08.
Since 1993, tritium in wastewater at the ATRC has been discharged to lined evaporation ponds, which should prevent migration to the aquifer. About $191 \mathrm{Ci}$ of tritium were released in wastewater to the ATRC lined evaporation ponds during 1999-2000 (S.M. Stoller Corporation, 2002a, 2002b). Data are unavailable for the total amount of tritium in wastewater discharged at the ATRC during 2001-08.

Reportable concentrations of tritium in water samples collected in April or October 2008 ranged from $810 \pm 70$ to $8,570 \pm 190 \mathrm{pCi} / \mathrm{L}$ and the tritium plume extended southsouthwestward in the general direction of groundwater flow (fig. 12). In 1991, the area of the plume in which concentrations exceeded the MCL was about $2.4 \mathrm{mi}^{2}$ (Bartholomay and others, 1995). Since 1997, tritium concentrations of water samples collected by the USGS from the Snake River Plain aquifer have not exceeded the MCL.

Long-term radioactive-decay processes and an overall decrease in tritium disposal rates since the 1960s (Davis, 2008) contributed to decreased concentrations of tritium in water from most wells at the INL during 2006-08. Tritium concentrations in water from several wells at and southsouthwest of the INTEC decreased or remained relatively constant during 2006-08 (fig. 13). Concentrations in water from well USGS 123 (fig. 6), southwest of the INTEC, decreased from 4,600 $\pm 300 \mathrm{pCi} / \mathrm{L}$ in October 2005 to $3,600 \pm 120 \mathrm{pCi} / \mathrm{L}$ in October 2008. Although the tritium concentration in water from well USGS 114 (fig. 6) was highest in $2008(8,570 \pm 190 \mathrm{pCi} / \mathrm{L})$, it was a decrease in concentration from the concentration of $10,500 \pm 500 \mathrm{pCi} / \mathrm{L}$ in October 2005. Tritium concentrations in water from well CFA LF 2-10 (fig. 6) decreased from 3,060 $\pm 320 \mathrm{pCi} / \mathrm{L}$ in October 2005 to $1,390 \pm 100 \mathrm{pCi} / \mathrm{L}$ in 2008 . The decrease in tritium concentrations in water from wells at and south-southwest of the INTEC likely is the result of decreased discharge of tritium to the percolation ponds since the early 1990s (Davis, 2008, fig. 9).

Tritium concentrations in water from well USGS 59, near the INTEC percolation ponds (iggs. 6 and $\underline{13}$ ), have decreased since 1980, but were unusually high in October 1983, 1985, 1991, and 1995, and 2002 (fig. 13). The higher concentrations in 1983 and 1985 correlate with higher annual discharge rates of tritium; however, annual discharge of tritium was low in 1991 and 1995 (Davis, 2008, fig. 9). In 1986, perched groundwater was detected outside the casing in well USGS 59. Following modifications to the well to prevent seepage of water into the well, a video log showed that some water from the perched zone was still seeping into the well. The higher concentrations in 1991, 1995, and 2002 could be the result of seepage from a perched zone. The higher concentrations also correlate with the use of the east infiltration pond and with disposal of tritium to the ponds. The lower concentrations in water from well USGS 59 in 1989, 1993, 1994, and from 1996 to 2000 correlate with years in which little or no tritium was discharged to the percolation ponds (Davis, 2008, fig. 9). 


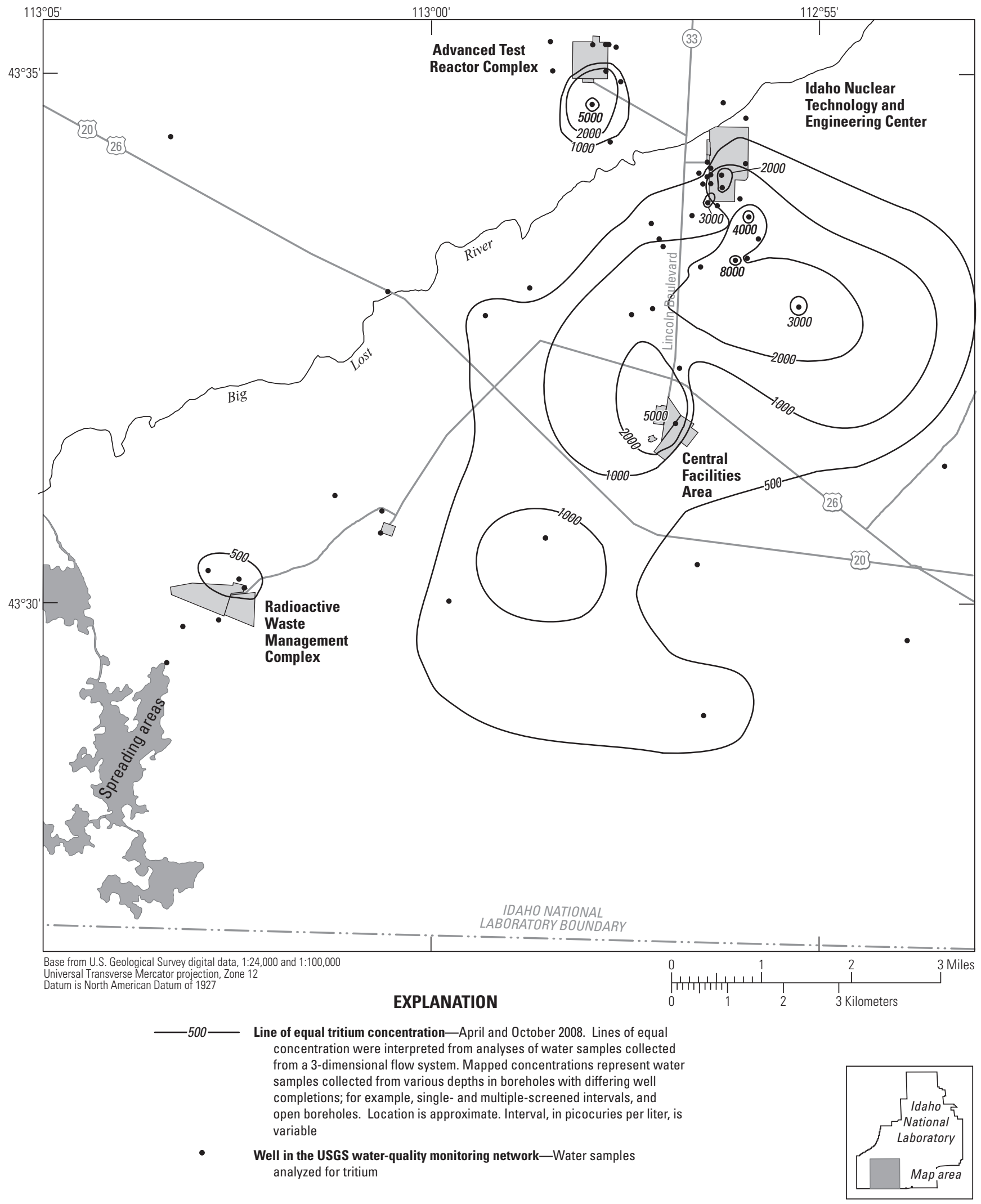

Figure 12. Distribution of tritium in water from wells at and near the Advanced Test Reactor Complex, Idaho Nuclear Technology and Engineering Center, Central Facilities Area, and Radioactive Waste Management Complex at the Idaho National Laboratory, Idaho, April or October 2008. 

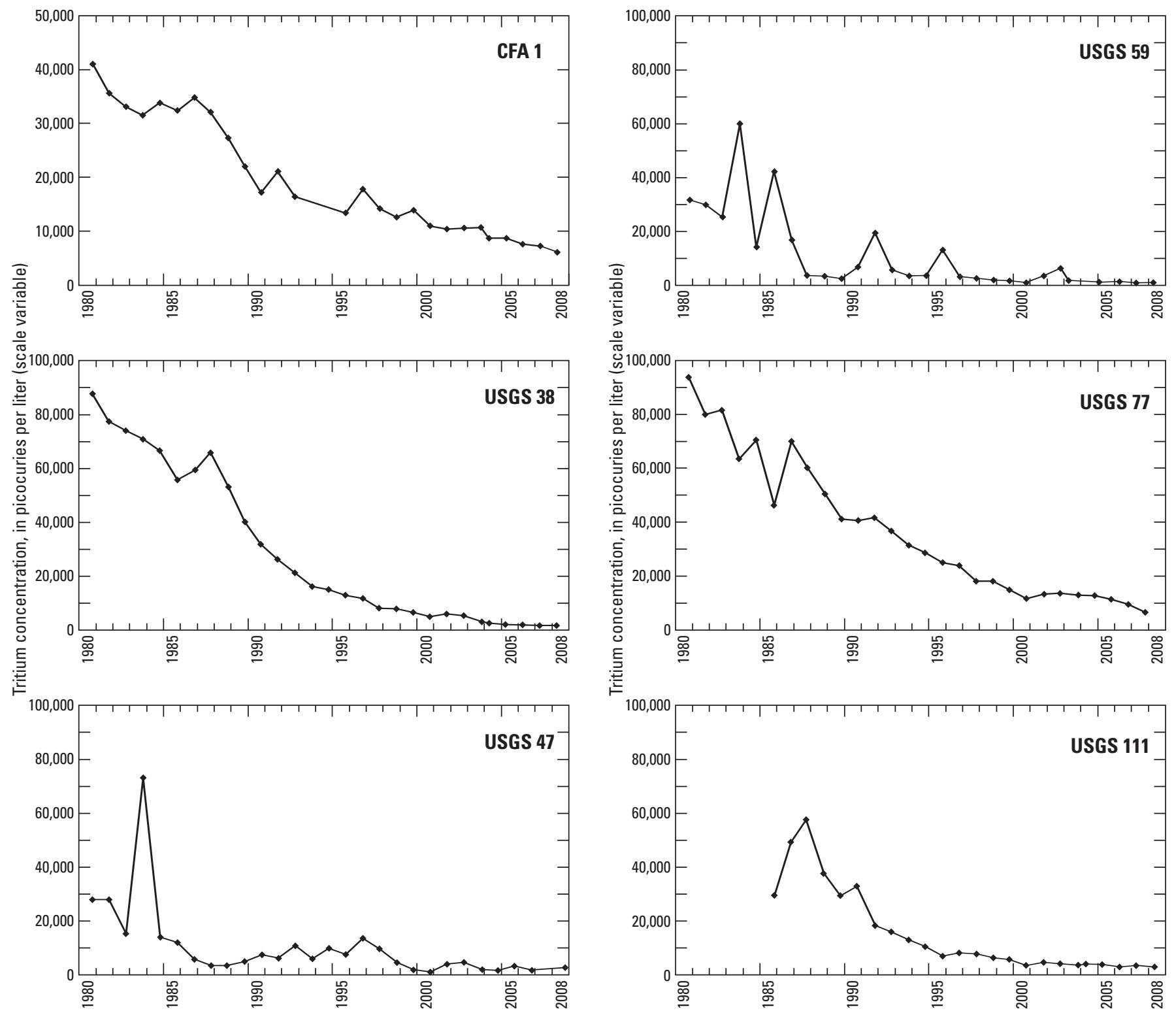

Figure 13. Tritium concentrations in water from six wells at and near the Central Facilities Areas (CFA) and Idaho Nuclear Technology and Engineering Center (INTEC), 1980-2008. Locations of wells are shown in figures 5 and $\underline{6}$. 
The slight increase in tritium concentrations in wells USGS $38,47,59,77$, and 111 between 2000 and 2001 (fig. 13), could have resulted from disposal of $0.03 \mathrm{Ci}$ of tritium (S.M. Stoller Corporation, 2002b) to the INTEC percolation ponds and from the lack of dilution by groundwater recharge because of low streamflows in the Big Lost River during 2000 (Davis, 2008). The lower concentrations in 2003-08 occur after the percolation ponds were taken out of service.

The greatest decrease in tritium concentrations in wells south of the INTEC disposal well during the 2006-08 reporting period was in well USGS 77, which decreased from $11,500 \pm 600 \mathrm{pCi} / \mathrm{L}$ in October 2005 to $5,620 \pm 150 \mathrm{pCi} / \mathrm{L}$ in October 2008. Concentrations of tritium in well CFA 1 (fig. 5) decreased from 8,700 $\pm 400 \mathrm{pCi} / \mathrm{L}$ in April 2005 to 6,300 \pm 200 in April 2008. Figure 13 shows graphs of tritium concentrations in other wells south of INTEC. Most concentrations were relatively constant during 2005-08 when uncertainties were considered.

Tritium concentrations in water from wells USGS 83 and EBR 1 (fig. 5) south and west of the INTEC, and in and near the tritium plume (fig. 12), were less than the reporting level during 2006-08. Well USGS 83 penetrates about $250 \mathrm{ft}$ of the Snake River Plain aquifer and well EBR 1 penetrates about $490 \mathrm{ft}$ of the aquifer. Most of the other wells in the tritium plume penetrate only the uppermost 50-200 $\mathrm{ft}$ of the aquifer. Tritium concentrations in water from wells USGS 83 and EBR 1 were less than the reporting level, possibly because of dilution by water from deeper zones, a phenomena described by Mann and Cecil (1990, p. 18) for these wells.

Prior to 1999, concentrations of tritium in water from wells near the southern boundary of the INL (USGS 1, 103, 105, 108, 109, 110A) (fig. 5), varied between exceeding and not exceeding the reporting levels (Pittman and others, 1988; Mann and Cecil, 1990; Bartholomay and others, 1997, 2000). During 1999-2005, concentrations of tritium in water from these wells and all wells sampled south of the INL boundary were less than the reporting level. During 2006 and 2007, water from well USGS 105 exceeded the reporting level with concentrations of $210 \pm 60$ and $270 \pm 80 \mathrm{pCi} / \mathrm{L}$, respectively. Well USGS 105 was not sampled in 2008 because the well was deepened and equipped with a multi-level Westbay ${ }^{\mathrm{TM}}$ packer sampling system. Water from the multi-level sampling system installed in well USGS 103 showed concentrations less than the reporting level in 2008 in the upper two zones that represent the zone of water sampled through 2005 (table 5), but did show concentrations greater than the reporting level in four deeper levels of the aquifer.

Water from various depths in all six wells equipped with the multi-level Westbay ${ }^{\mathrm{TM}}$ packer sampling system (figs. 5 and $\underline{6}$, table 5) was sampled and analyzed for tritium during 2006-08. Results showed that water from one or more zones in each well contained concentrations of tritium greater than the reporting level. The concentrations greater than the reporting levels are attributed to wastewater disposal at NRF, INTEC, and ATRC (Bartholomay and Twining, 2010). Bartholomay and Twining (2010) give a comprehensive analysis of the vertical variation in tritium concentrations and possible sources of the tritium for the different zones in each well.

\section{Strontium-90}

A strontium-90 plume developed in the Snake River Plain aquifer from wastewater disposal at the INL. Strontium-90 has a half-life of 29.1 years (Walker and others, 1989, p. 29). The MCL for strontium-90 in drinking water is $8 \mathrm{pCi} / \mathrm{L}$ (U.S. Environmental Protection Agency, 2001). During 1952-98, about $24 \mathrm{Ci}$ of strontium- 90 was in wastewater that was injected directly into the aquifer through the disposal well and was discharged to percolation ponds at the INTEC (Bartholomay and others, 2000). During this period, about $93 \mathrm{Ci}$ of strontium-90 also was discharged to radioactivewaste infiltration and evaporation ponds at the ATRC. During 1962-63, more than $33 \mathrm{Ci}$ of strontium-90 in wastewater was discharged into a pit at the INTEC (Robertson and others, 1974, p. 117). In 1972, about $18,100 \mathrm{Ci}$ of strontium-90 was leaked at the INTEC Tank Farm (fig. 7) (Cahn and others, 2006). During 1996-98, about $0.03 \mathrm{Ci}$ of strontium-90 was discharged to percolation ponds at the INTEC (Bartholomay and others, 2000). During 1999, less than $0.001 \mathrm{Ci}$ of strontium-90 was discharged at the INTEC or at the ATRC (S.M. Stoller Corporation, 2002a, table 7-2); during 2000, $0.21 \mathrm{Ci}$ of strontium-90/yttrium-90 was discharged at the ATRC (S.M. Stoller Corporation, 2002b, table 6-2). Data are not available for strontium-90 discharged during 2001-08.

During April or October 2008, water from 52 aquifer wells was sampled for strontium-90 throughout the INL. Concentrations of strontium-90 in water from 24 wells exceeded the reporting level. Reportable concentrations of strontium-90 in the aquifer wells ranged from $2.2 \pm 0.7 \mathrm{pCi} / \mathrm{L}$ in water from well Site 9 , to $32.7 \pm 1.2 \mathrm{pCi} / \mathrm{L}$ in water from well USGS 47. The area of the strontium-90 plume near the INTEC extended south-southwestward in the general direction of groundwater flow (fig. 14). The concentrations in water from wells near and southwest of INTEC have varied since 1980; however, all wells have shown an overall decrease in strontium-90 concentration (fig. 15). Six Westbay ${ }^{\mathrm{TM}}$ equipped wells were sampled in August and September 2008 and did not contain reportable concentrations of strontium-90.

Concentrations in water from wells at and near the INTEC exceeded the reporting level in most years during 1980-2008 (Davis, 2008, table 6; this report). Figure 15 shows how the concentration in these wells has varied since 1980 . 
Table 5. Tritium concentrations in water sampled at multiple depths in six wells equipped with multi-level Westbay ${ }^{\mathrm{TM}}$ packer sampling systems, $2006-08$.

[Well No.: Well locations are shown in figures 5 and $\underline{6}$. Concentrations and associated uncertainties in picocuries per liter. Analytical uncertainties are reported as 1 times the sample standard deviation. Concentrations equal to or greater than 3 times the sample standard deviation are considered greater than the reporting level and are bold. Symbol: \pm , plus or minus. Abbreviations: ft BLS, feet below land surface; USGS, U.S. Geological Survey]

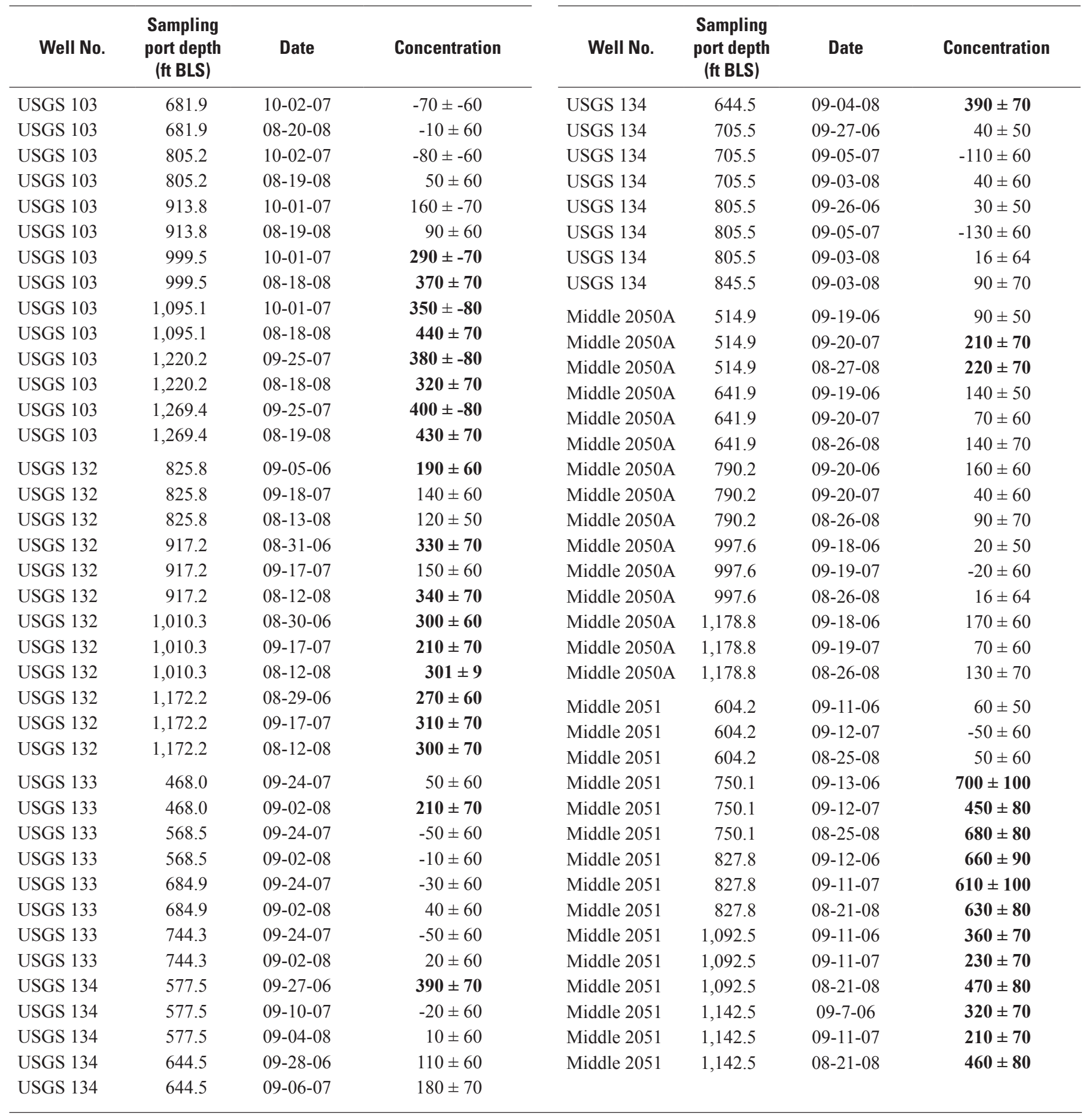




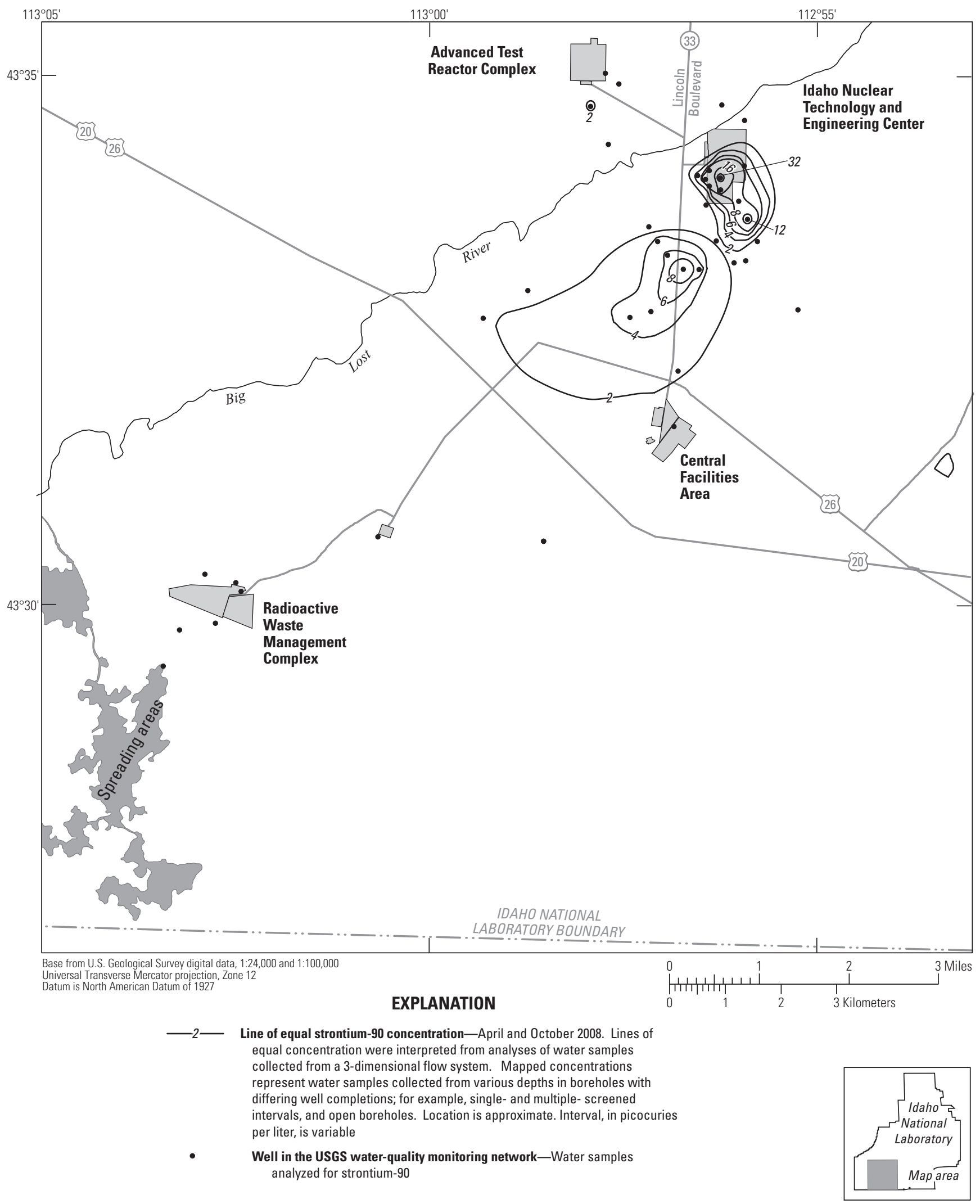

Figure 14. Distribution of strontium-90 in water from wells at and near the Advanced Test Reactor Complex (ATRC), Idaho Nuclear Technology and Engineering Center (INTEC), Central Facilities Area (CFA), and Radioactive Waste Management Complex (RWMC), Idaho National Laboratory (INL), Idaho, April and October 2008. 

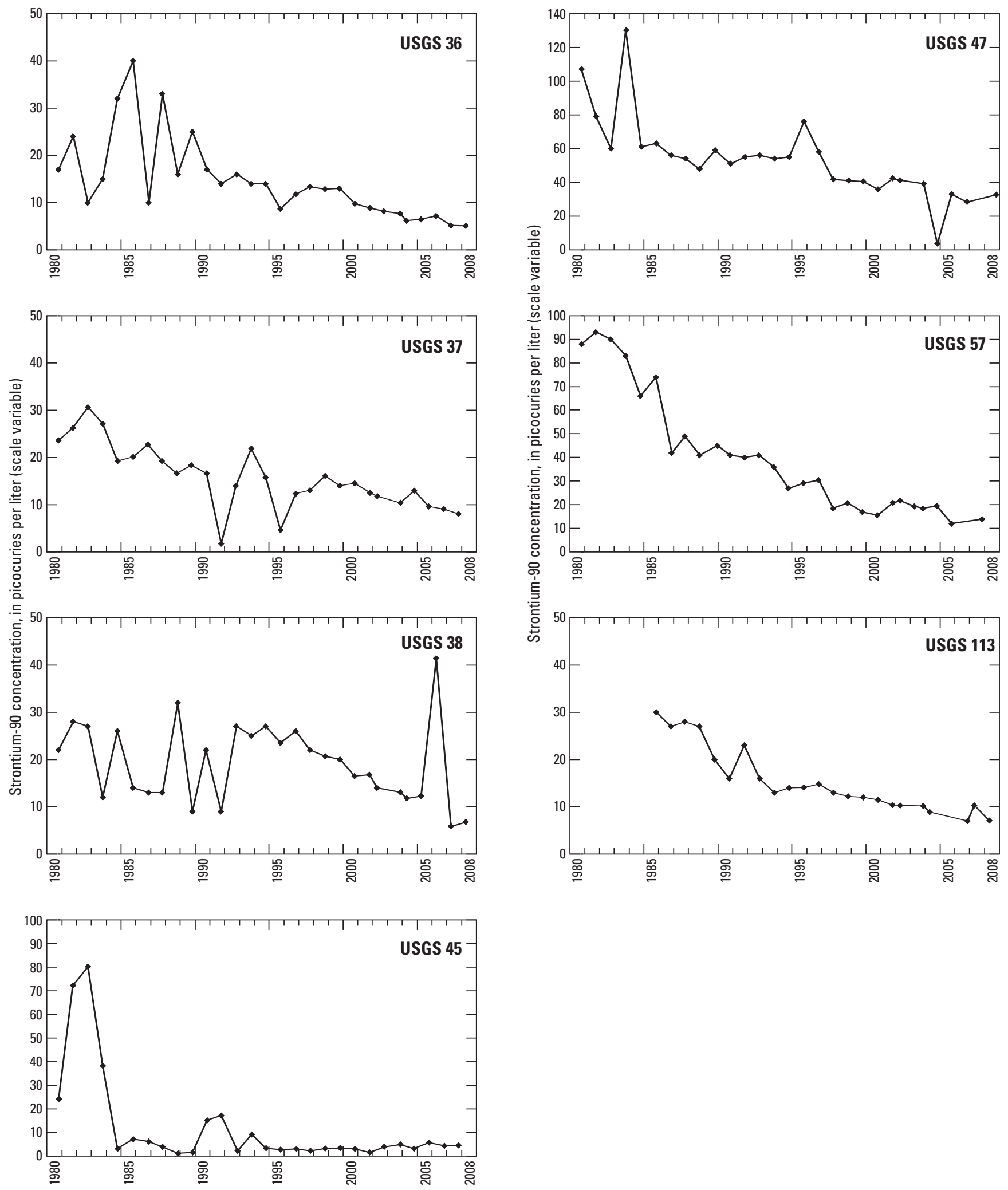

Figure 15. Strontium-90 concentrations in water from seven wells at and near the Idaho Nuclear Technology and Engineering Center (INTEC), 1980-2008. Location of wells shown in figure 6. 
Before 1989, strontium-90 concentrations in most wells had been decreasing likely because of factors including radioactive decay, diffusion, dispersion, changes in disposal methods, and dilution from natural recharge (Orr and Cecil, 1991, p. 35). The fluctuating concentrations in water from most of the wells sampled during 2006-08 could have resulted at least partly from variations in recharge from the Big Lost River. An increase in disposal of other chemical constituents into the percolation ponds also could have affected the exchange capacity of strontium-90 in the unsaturated zone (Bartholomay and others, 1997).

Strontium-90 has not been detected in the eastern Snake River Plain aquifer beneath the ATRC partly because of the exclusive use of waste-disposal ponds and lined evaporation ponds rather than the disposal well for radioactive-wastewater disposal at that facility. Sorption processes in sediments in the unsaturated zone beneath the radioactive waste-disposal pond could have minimized or prevented strontium-90 migration to the aquifer at the ATRC. Additionally, the stratigraphy beneath the ATRC includes more sediment than the stratigraphy beneath the INTEC (Anderson, 1991, p. 22-28).

In 1988, a DOE contractor was given the responsibility for monitoring areas around TAN and the TAN disposal well as part of the Environmental Restoration Program. The USGS collected water samples from wells in the area for special studies in 1989, but the USGS has not collected any other water samples in this area since December 1989. During 1988-96, four water samples analyzed for strontium-90 from well USGS 24, just south of the TAN, yielded one reportable concentration in 1990.

\section{Cesium-137}

From 1952 to 2000 , about $138 \mathrm{Ci}$ of cesium-137 in wastewater was discharged to the ATRC radioactive-waste infiltration and lined evaporation ponds and about $23 \mathrm{Ci}$ was discharged to the INTEC disposal well and infiltration ponds. In 1972, an additional 19,100 Ci of cesium-137 leaked at the INTEC Tank Farm (fig. 7) (Cahn and others, 2006). During 1999-2000, about 0.009 Ci was discharged to the ATRC lined evaporation ponds, and less than $0.001 \mathrm{Ci} / \mathrm{yr}$ was discharged to the INTEC percolation ponds (S.M. Stoller Corporation, 2002a). Data are not available for cesium-137 discharged during 2001-08. The half-life of cesium-137 is 30.17 years (Walker and others, 1989, p. 34).

Concentrations of cesium-137 in water from wells USGS 40 and 47, near the INTEC (ig. 6) exceeded the reporting levels through 1985 (Orr and Cecil, 1991, p. 35) but they have not exceeded the reporting level since 1985. The absence of detectable concentrations of cesium-137 probably resulted from discontinuation of wastewater discharge to the INTEC disposal well and to sorption processes in the unsaturated and perched groundwater zones.
Before 1990, cesium-137 concentrations in water from the TAN disposal well (fig. 5) exceeded the reporting level because of wastewater discharge to the well. Water samples were not collected by the USGS after 1989, because the responsibility for monitoring the TAN disposal well was turned over to a DOE contractor. The cesium-137 concentration in water from the TAN Disposal well at that time was 4,400 200 pCi/L (Davis, 2006b; U.S. Geological Survey, 2010c).

During 2006-08, concentrations of cesium-137 were less than the reporting level in water from all 75 wells sampled by the USGS at the INL, including all zones sampled in wells equipped with Westbay ${ }^{\mathrm{TM}}$ systems.

\section{Plutonium}

In 1974, the USGS began monitoring plutonium-238 and plutonium-239, -240 (undivided) in wastewater discharged to the eastern Snake River Plain aquifer through the disposal well (fig. 6) at the INTEC. During 1974-2000, about $0.26 \mathrm{Ci}$ of plutonium in wastewater was discharged to the disposal well and percolation ponds at the INTEC (Davis, 2008). Discharge data for plutonium in wastewater are not available for 2001-08.

Before 1974, alpha radioactivity from disintegration of plutonium was not separable from the monitored, undifferentiated alpha radioactivity. The half-lives of plutonium-238, plutonium-239, and plutonium-240 are 87.7, 24,100 , and 6,560 years, respectively (Walker and others, 1989, p. 46). Because of radioactive wastewater discharged to the disposal well at INTEC, concentrations of plutonium isotopes in some water samples from wells USGS 40 and 47 near INTEC (fig. 6) through January 1987 exceeded the reporting level (Orr and Cecil, 1991, p. 37). Concentrations in water samples collected from these wells since 1987 have been less than the reporting level.

Plutonium isotopes in water from the TAN disposal well (fig. 5) exceeded the reporting level because of radioactive-wastewater discharged before 1972. Because the responsibility for monitoring the TAN disposal well was turned over to a DOE contractor in 1988, the only water samples collected by the USGS since that time were collected in March and December 1989. The concentration of plutonium-238 in water from the TAN disposal well at that time was $0.26 \pm 0.04 \mathrm{pCi} / \mathrm{L}$, and the concentration of plutonium-239, -240 (undivided) was $0.71 \pm 0.06 \mathrm{pCi} / \mathrm{L}$ (Bartholomay and others, 1995).

During 2006-08, concentrations of plutonium-238 and plutonium-239, -240 (undivided) in water from all 28 wells sampled and all zones in wells equipped with Westbay ${ }^{\mathrm{TM}}$ systems were less than the reporting level. 


\section{Americium-241}

Americium-241 is a decay product of plutonium-241. Plutonium isotopes have been detected in wastewater discharged to the Snake River Plain aquifer at the INL and they are in wastes buried at the RWMC. The half-life of americium-241 is 432.7 years (Walker and others, 1989 , p. 46). Concentrations of americium-241 in water samples collected between September 1972 and July 1982 from wells USGS 87, 88, 89, and 90 at the RWMC (fig. 6) and in water samples collected through 1988 from the TAN disposal well (fig. 5) exceeded the reporting level (Orr and Cecil, 1991, p. 38-39). During 1992-95, concentrations of americium-241 in water samples from two wells were equal to the reporting level. On October 2, 1992, the concentration in water from well USGS 37 was $0.09 \pm 0.03 \mathrm{pCi} / \mathrm{L}$; on April 20, 1993, the concentration in water from well USGS 120 was $0.06 \pm 0.02 \mathrm{pCi} / \mathrm{L}$ (Bartholomay and others, 1997). The concentration in one water sample collected on April 12, 2001, from the RWMC Production Well (RWMC PROD) was $0.003 \pm 0.001 \mathrm{pCi} / \mathrm{L}$, equal to the reporting level (Davis, 2008). During 2006-2008, concentrations in water from all 28 wells sampled and all zones in Westbay ${ }^{\mathrm{TM}}$ equipped wells were less than the reporting level.

\section{Gross Alpha- and Beta-Particle Radioactivity}

Gross alpha- and beta-particle radioactivity is a measure of the total radioactivity given off as alpha and beta particles during the radioactive decay process. The radioactivity is usually reported as if it occurred as one radionuclide. Gross alpha and beta measurements are used to screen for radioactivity in the aquifer as a possible indicator of groundwater contamination. Water samples collected during 2006-08 were analyzed for gross alpha- and gross beta-particle radioactivity by RESL. In 2008, RESL increased the sensitivity of the gross alpha- and gross beta- particle radioactivity and changed the radionuclide reported for gross alpha from plutonium-239 to thorium-230, and for gross beta from cesium-137 to strontium-90/yttrium-90. The minimum detectable activity decreased from about 1.6 to $1.5 \mathrm{pCi} / \mathrm{L}$ for gross alpha and from about 6.4 to $3.4 \mathrm{pCi} / \mathrm{L}$ for gross beta, allowing for increased detectable concentrations for 2008 data (Bartholomay and Twining, 2010).

During 2006-07, concentrations of gross alpha radioactivity in water from 58 wells sampled were less than the reporting levels. In 2008, reportable concentrations of gross alpha radioactivity were observed in 24 wells, and ranged from $2.3 \pm 0.7$ to $6.6 \pm 1.3 \mathrm{pCi} / \mathrm{L}$. This likely is a result of RESL increasing the sensitivity and changing the radionuclide reported for gross alpha radioactivity from plutonium-239 to thorium-230.
During 2006, concentrations of gross beta radioactivity in water from ten wells were reportable; in 2007, concentrations in water from seven wells were reportable. During 2008, concentrations of gross beta radioactivity water from 37 wells were reportable ranging from $2.8 \pm 0.9$ to $21.6 \pm 1.8 \mathrm{pCi} / \mathrm{L}$, again likely reflecting the increase in sensitivity and change in the reporting radionuclide from cesium-137 to strontium-90/ yttrium- 90 by RESL.

\section{Chromium}

Wastewater from ATRC cooling-tower operations contained an estimated $24,000 \mathrm{lb}$ of chromium discharged to an infiltration pond during 1952-64 and an estimated 31,000 $\mathrm{lb}$ discharged to an injection well during 1965-72 (Mann and Knobel, 1988, p. 7). In October 1972, chromium used as a corrosion inhibitor in cooling-tower operations was replaced by a polyphosphate. No disposal of chromium to the subsurface at the ATRC was reported after 1972.

During 1971-83, about $265 \mathrm{lb}$ of chromium in wastewater were discharged to the disposal well at INTEC and $720 \mathrm{lb}$ of chromate were discharged at the Power Burst Facility (PBF, fig. 1) (Cassidy, 1984, p. 3). About $130 \mathrm{lbs}$ of chromium were discharged to the INTEC percolation ponds during 1992-98 (Bartholomay and others, 2000). Information is not available on the total amount of chromium discharged at the INL during 1984-1991 and 1999-2008.

Background concentrations of chromium in the Snake River Plain aquifer range from 2 to $3 \mu \mathrm{g} / \mathrm{L}$ (Orr and others, 1991, p. 41). In April 2005, the MCL of $100 \mu \mathrm{g} / \mathrm{L}$ (U.S. Environmental Protection Agency, 2001) for total chromium in drinking water was equaled in water from one well, USGS 65 , south of ATRC (fig. 6). In 2008, the concentration of chromium in water from that well was $93 \mu \mathrm{g} / \mathrm{L}$, just less than the MCL, and concentrations steadily decreased during 2006-08. Concentrations in water samples from 75 other wells sampled ranged from 1.2 to $28.3 \mu \mathrm{g} / \mathrm{L}$. The LRL for chromium ranged from 0.4 to $2 \mu \mathrm{g} / \mathrm{L}$ during 2006-08; consequently, concentrations within that range were designated according to those LRLs as detections or nondetections during 2006-08.

Variation in chromium concentrations with depth in Westbay ${ }^{\mathrm{TM}}$ equipped wells during $2006-08$ is shown in figure 16. In 2007 and 2008, chromium concentrations in water samples from well Middle 2050A were higher in the uppermost zone ( 7 to $8 \mu \mathrm{g} / \mathrm{L}$ ) than concentrations in the four lower zones ( 1 to $4 \mu \mathrm{g} / \mathrm{L}$ ). Chromium concentrations in water samples from well Middle 2051 were higher in the four lower zones, with concentrations ranging from about 6 to $8 \mu \mathrm{g} / \mathrm{L}$, and a lower concentration in the uppermost zone $(604.2 \mathrm{ft}$, about $1 \mu \mathrm{g} / \mathrm{L}$ ). Concentrations in the water samples from the uppermost zone in well USGS 103 (681.9 ft) collected in 2007 and 2008 were less than $1 \mu \mathrm{g} / \mathrm{L}$, and the concentrations in the rest of the zones generally were consistent, with concentrations ranging from about 5 to $6 \mu \mathrm{g} / \mathrm{L}$. The highest 

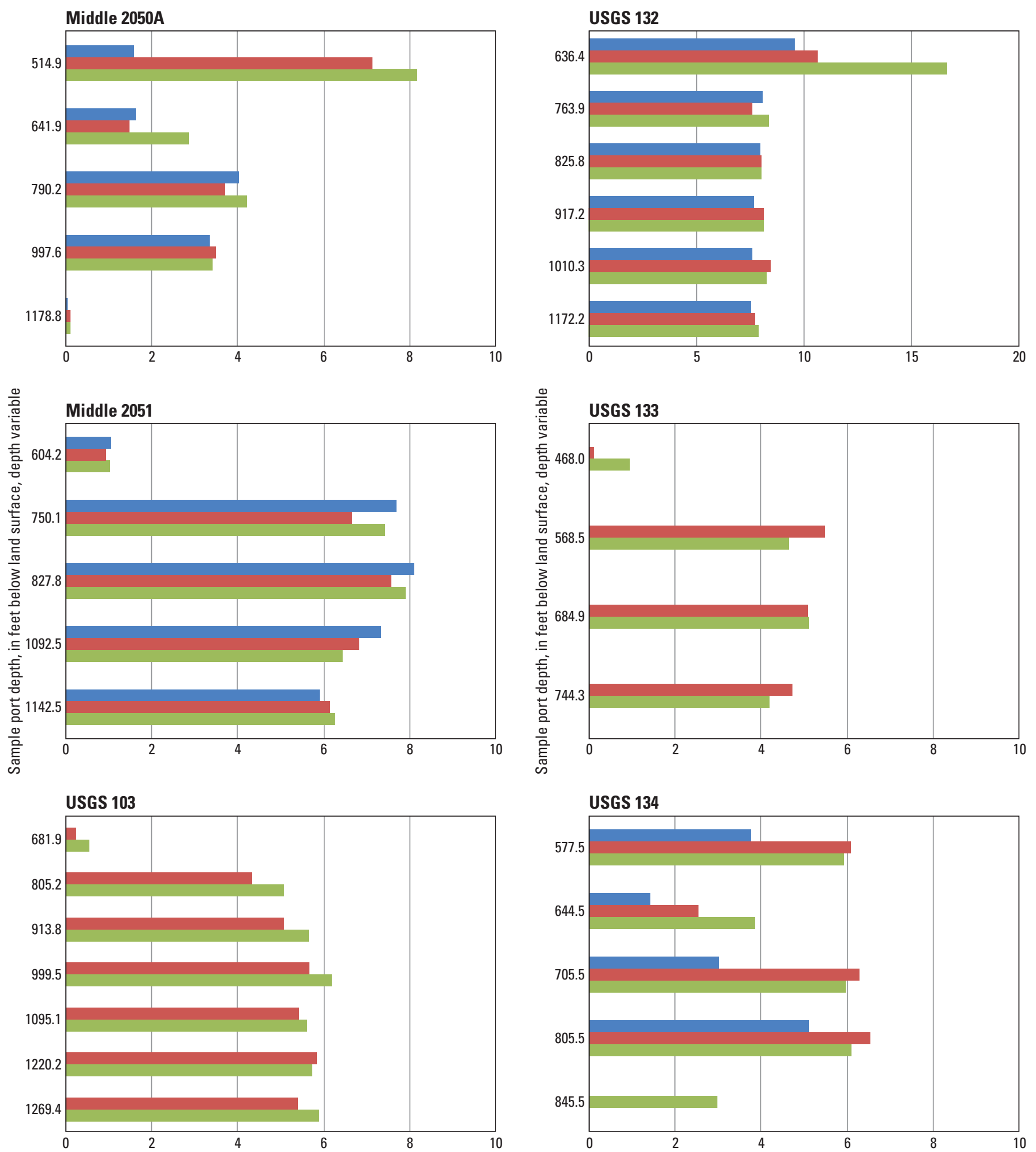

Chromium concentration, in micrograms per liter, scale variable

\section{EXPLANATION}

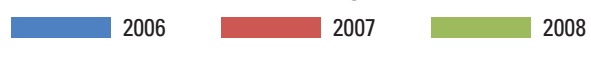

Figure 16. Vertical distribution of dissolved chromium in water from six wells (Middle 2050A, Middle 2051, USGS 103, 132, 133, and 134) equipped with multi-level Westbay ${ }^{\mathrm{TM}}$ packer sampling systems, 2006-08. 
concentrations of chromium in water samples were from the uppermost zone of well USGS $132(636.4 \mathrm{ft})$ at $16.7 \mu \mathrm{g} / \mathrm{L}$ in 2008 , and the concentrations in the rest of the zones generally were consistent with concentrations ranging from about 7.9 to $8.4 \mu \mathrm{g} / \mathrm{L}$ in 2008 . Chromium concentrations in water samples from wells USGS 133 in the uppermost zone (468.0 ft) were less than $1 \mu \mathrm{g} / \mathrm{L}$ and concentrations generally were consistent ranging from 4.2 to $5.5 \mu \mathrm{g} / \mathrm{L}$ in the deeper zones. In 2008, the highest concentration was in water samples from the fourth deepest zone of well USGS 134 (805.5 ft) and was $6.1 \mu \mathrm{g} / \mathrm{L}$; the lowest concentration for that well was found in the deepest zone $(845.5 \mathrm{ft})$ at $3.0 \mu \mathrm{g} / \mathrm{L}$.

\section{Sodium}

During 1989-98, an estimated average annual 1.3 million $\mathrm{lb} / \mathrm{yr}$ of sodium in wastewater were discharged at the INL (Bartholomay and others, 1995, 1997, and 2000). During 1996-98 about 708,000 lb/yr of sodium were discharged to the INTEC percolation ponds; about 58,000 lb/ yr were discharged to the ATRC chemical-waste infiltration pond; about 524,000 lb/yr were discharged to the NRF industrial-waste ditch; and about 5,000 lb/yr were discharged at CFA (Bartholomay and others, 2000). The total amount of sodium in wastewater discharged at individual facilities from 1999-2008 has not been compiled.

The background concentration of sodium in water from the Snake River Plain aquifer near the INL generally is less than $10 \mathrm{mg} / \mathrm{L}$ (Robertson and others, 1974, p. 155). In October 2005, concentrations in water from most wells in the southern part of the INL were greater than $10 \mathrm{mg} / \mathrm{L}$.

Concentrations of sodium in water from wells near the INTEC generally have varied since 1984 when disposal practices were changed from injection to the disposal well to discharge to percolation ponds (figs. 6 and 17). During 1999-2008, the higher concentrations of sodium were in water from wells at or near INTEC. During 2006-08, the highest sodium concentration in water samples from aquifer wells near the INTEC was $40 \mathrm{mg} / \mathrm{L}$ in a water sample from well USGS 77 (fig. 6). Concentrations of sodium in water from other wells south of the INTEC during 2006-08 generally were less than or equal to sodium concentrations detected in October 2005, with the exception of well USGS 47, which was slightly higher in 2008 (fig. 17). Bartholomay (2009) noted iodine-129 increases in several wells near INTEC during 2007 and attributed the increases to recharge from the Big Lost River in 2006 moving water from the perched groundwater bodies below INTEC into the aquifer. This also may be the reason for the variability in concentration of sodium in wells USGS 37 and 47 during 2006-08 (fig. 17).

In October 2008, sodium concentrations in water from wells USGS 88 and 120 (fig. 6), near the RWMC, were 45 and $26 \mathrm{mg} / \mathrm{L}$, respectively, slightly higher than the October 2005 concentrations.
In May 2008, the sodium concentration in water from well MTR Test at the ATRC near the chemical waste pond (fig. 6) was $9 \mathrm{mg} / \mathrm{L}$, significantly less than the concentration of $42 \mathrm{mg} / \mathrm{L}$ in 1998 and about the same as the concentration in March 2005. This concentration decrease may be a result of the discontinued use of the chemical waste pond in 1999.

The vertical distribution of sodium concentrations in wells equipped with Westbay ${ }^{\mathrm{TM}}$ systems are shown in figure 18. Concentrations in most wells generally were consistent with depth, except for well USGS 132. During 2006-08, the concentration in the uppermost zone $(636.4 \mathrm{ft})$ of well USGS 132 was much higher (about 26-30 mg/L) than concentrations in the deeper zones $(9-12 \mathrm{mg} / \mathrm{L})$.

\section{Chloride}

About 2.3 million $\mathrm{lb} / \mathrm{yr}$ of chloride in wastewater was discharged to infiltration ponds at the INL during 1996-98, an increase from the estimated 1.5 million $\mathrm{lb} / \mathrm{yr}$ discharged during 1992-95 (Bartholomay and others, 1997, p. 36). Of the 2.3 million $\mathrm{lb} / \mathrm{yr}$ discharged during 1996-98, about 1.17 million $\mathrm{lb} / \mathrm{yr}$ were discharged to the INTEC percolation ponds (fig. 3; Bartholomay and others, 2000), which was about the same amount discharged during 1986-95 (Orr and Cecil, 1991, p. 40; Bartholomay and others, 1995, p. 31; Bartholomay and others, 1997, p. 36). Information has not been compiled for the total amount of chloride discharged in wastewater during 1999-2008.

The background chloride concentration in water from the Snake River Plain aquifer at the INL generally is about $15 \mathrm{mg} / \mathrm{L}$ (Robertson and others, 1974, p. 150). In 2008, concentrations of chloride in most water samples from wells south of the INTEC and at the CFA (ig. 19) exceeded $20 \mathrm{mg} / \mathrm{L}$. The secondary MCL for chloride in drinking water is 250 mg/L (U.S. Environmental Protection Agency, 2001).

Chloride concentrations in water from wells south of the INTEC generally increased because of increased chloride disposal to the percolation ponds since 1984 when discharge of wastewater to the INTEC disposal well was discontinued. Although variable, the concentrations show an overall increase through the late 1990s, and overall decrease since the late 1990s, with the exception of well USGS 59 (fig. 20). Chloride concentrations in water from USGS 59, near the INTEC percolation ponds, varied during 1984-2005; concentrations were unusually high in October 1991, 1995, and 2002 (fig. 20). The higher concentrations probably were caused by seepage down the well from the perched groundwater zone; chloride concentrations in perched groundwater wells near the percolation ponds were about $270 \mathrm{mg} / \mathrm{L}$ in 1991 and 1995 (Bartholomay and others, 1997) and averaged about $175 \mathrm{mg} / \mathrm{L}$ in five perched groundwater wells in 2002 (Davis, 2008, table 13). 

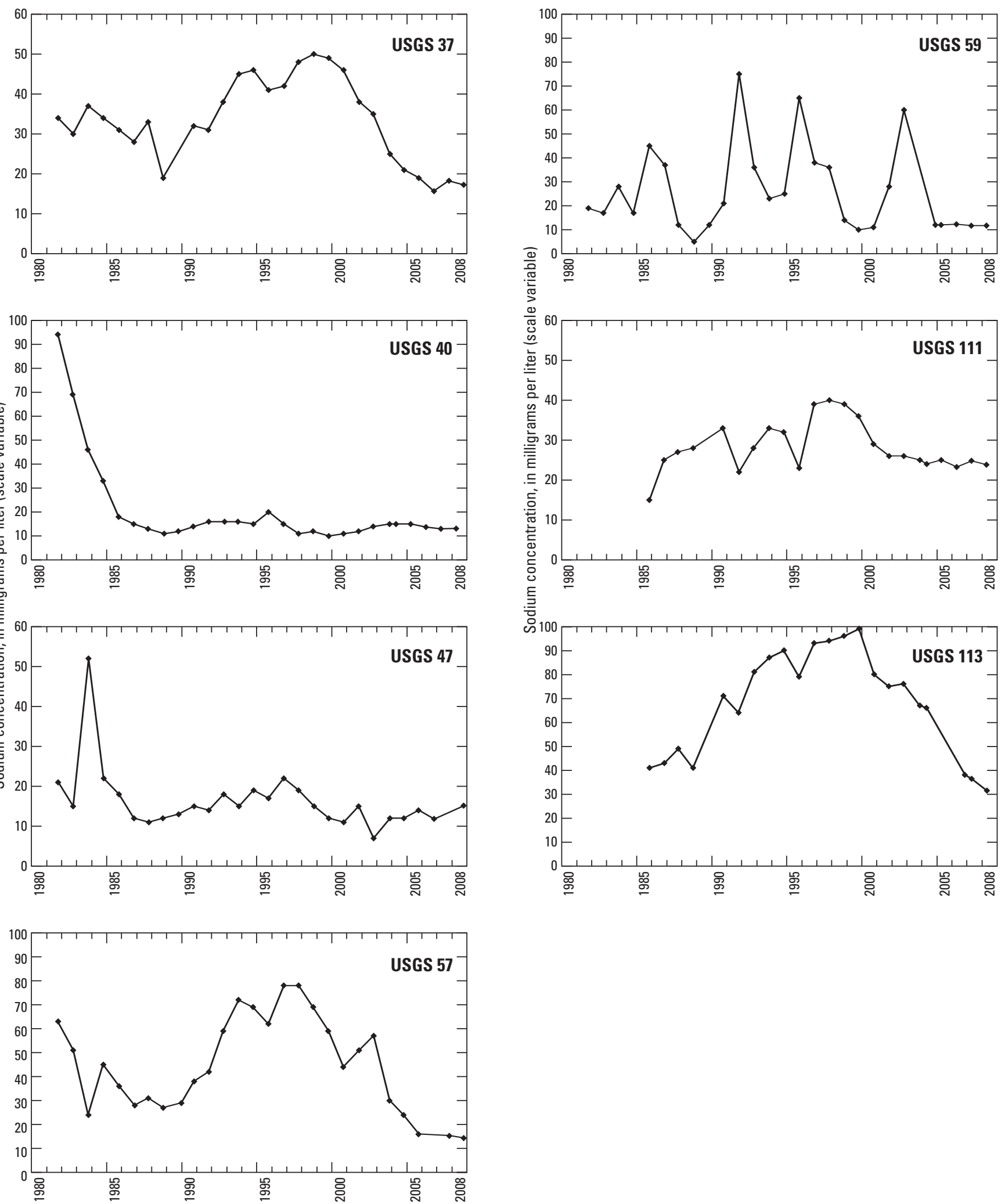

Figure 17. Dissolved sodium concentrations in water from seven wells at and near the Idaho Nuclear Technology and Engineering Center (INTEC), 1980-2008. Location of wells shown in figure 6. 
Middle 2050A
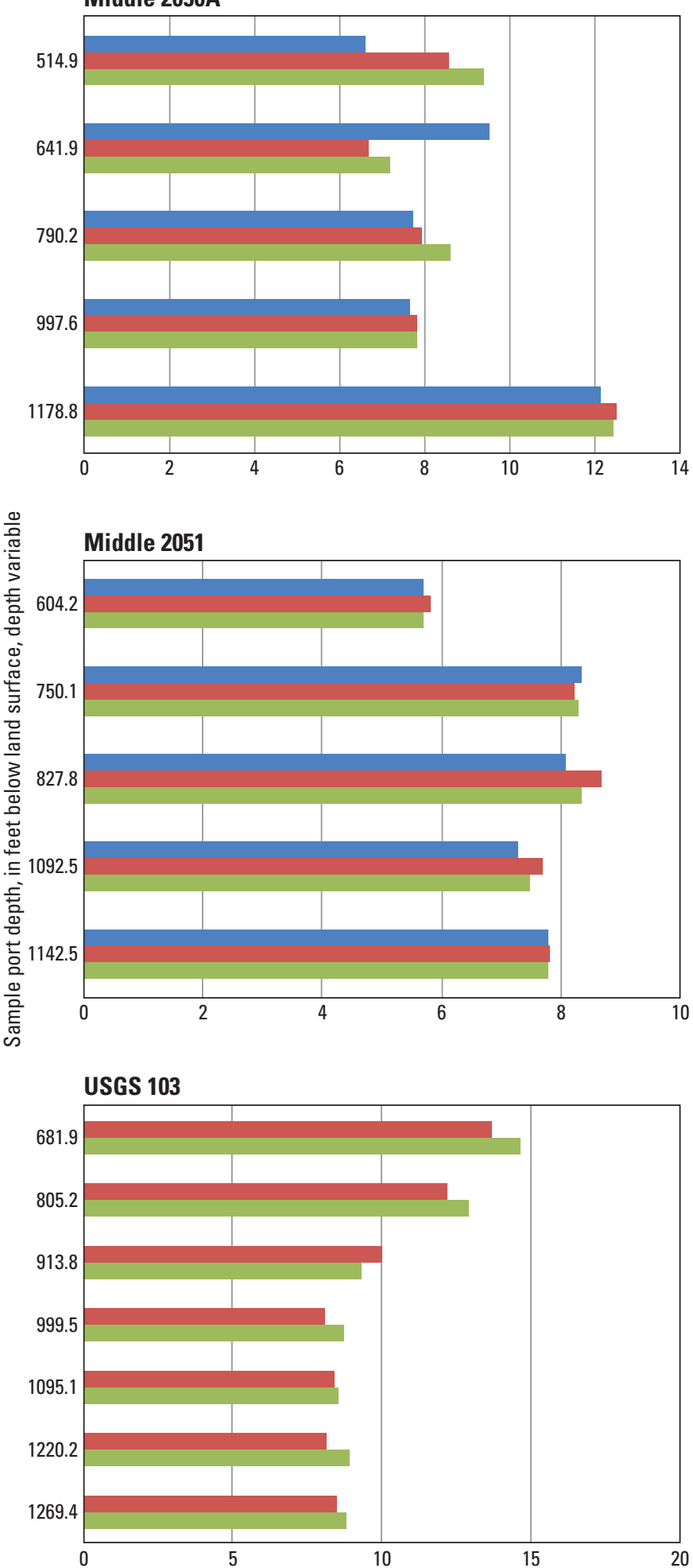
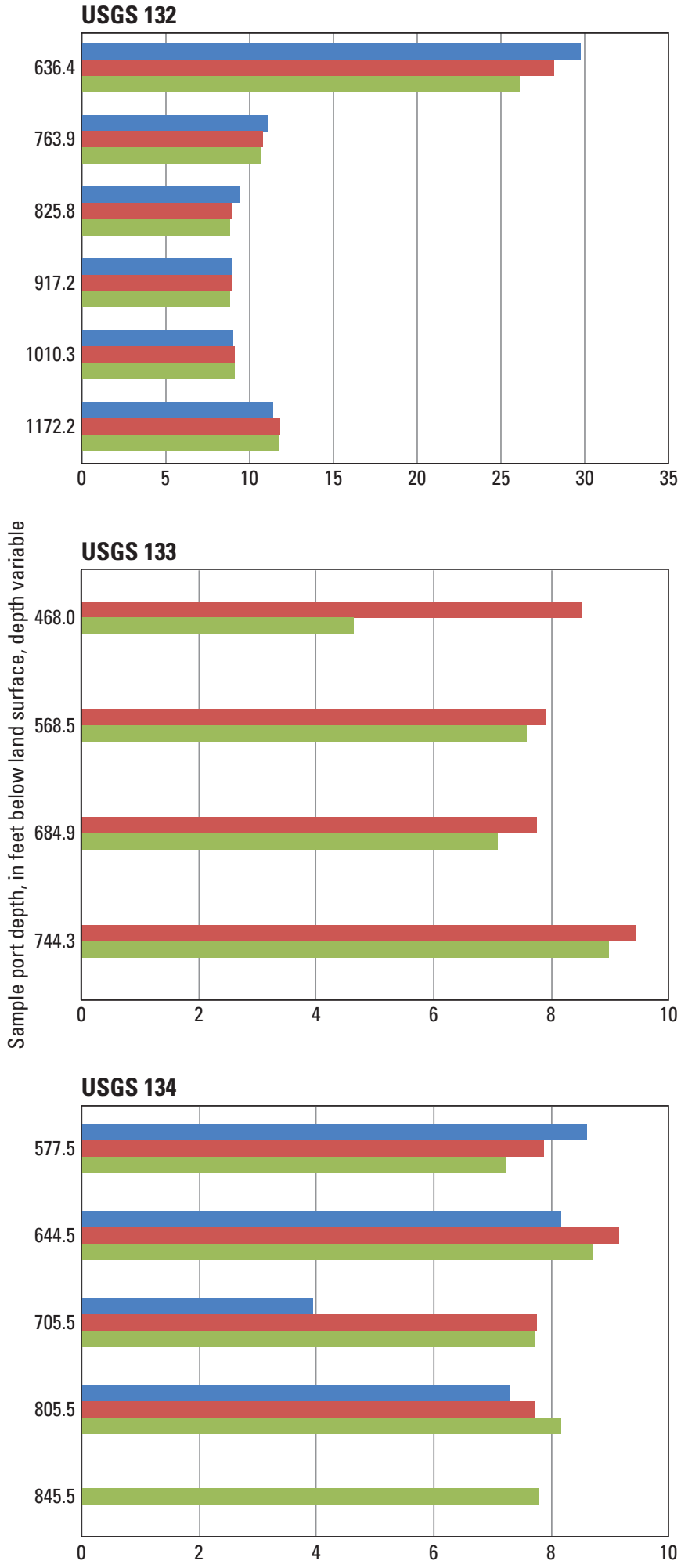

Sodium concentration, in milligrams per liter, scale variable

\section{EXPLANATION}

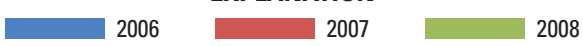

Figure 18. Vertical distribution of dissolved sodium in water from six wells equipped with multi-level Westbay ${ }^{\top \mathrm{M}}$ packer sampling systems, 2006-08. 

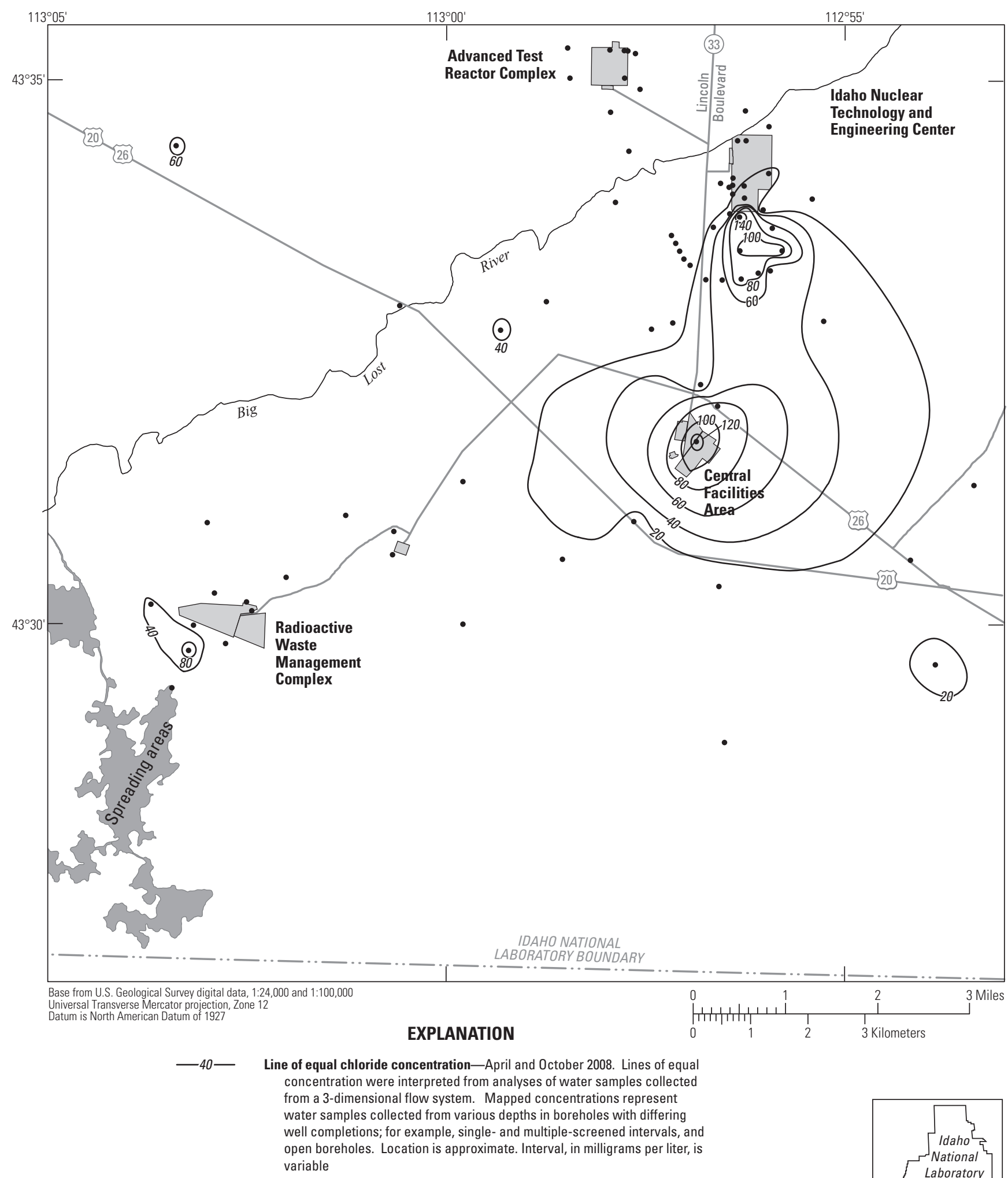

- Well in the USGS water-quality monitoring network-Water samples analyzed for chloride

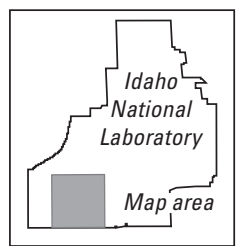

Figure 19. Distribution of chloride in water from wells at and near the Advanced Test Reactor Complex (ATRC), Idaho Nuclear Technology and Engineering Center (INTEC), Central Facilities Area (CFA), and Radioactive Waste Management Complex (RWMC), Idaho National Laboratory (INL), Idaho, April or October 2008. 

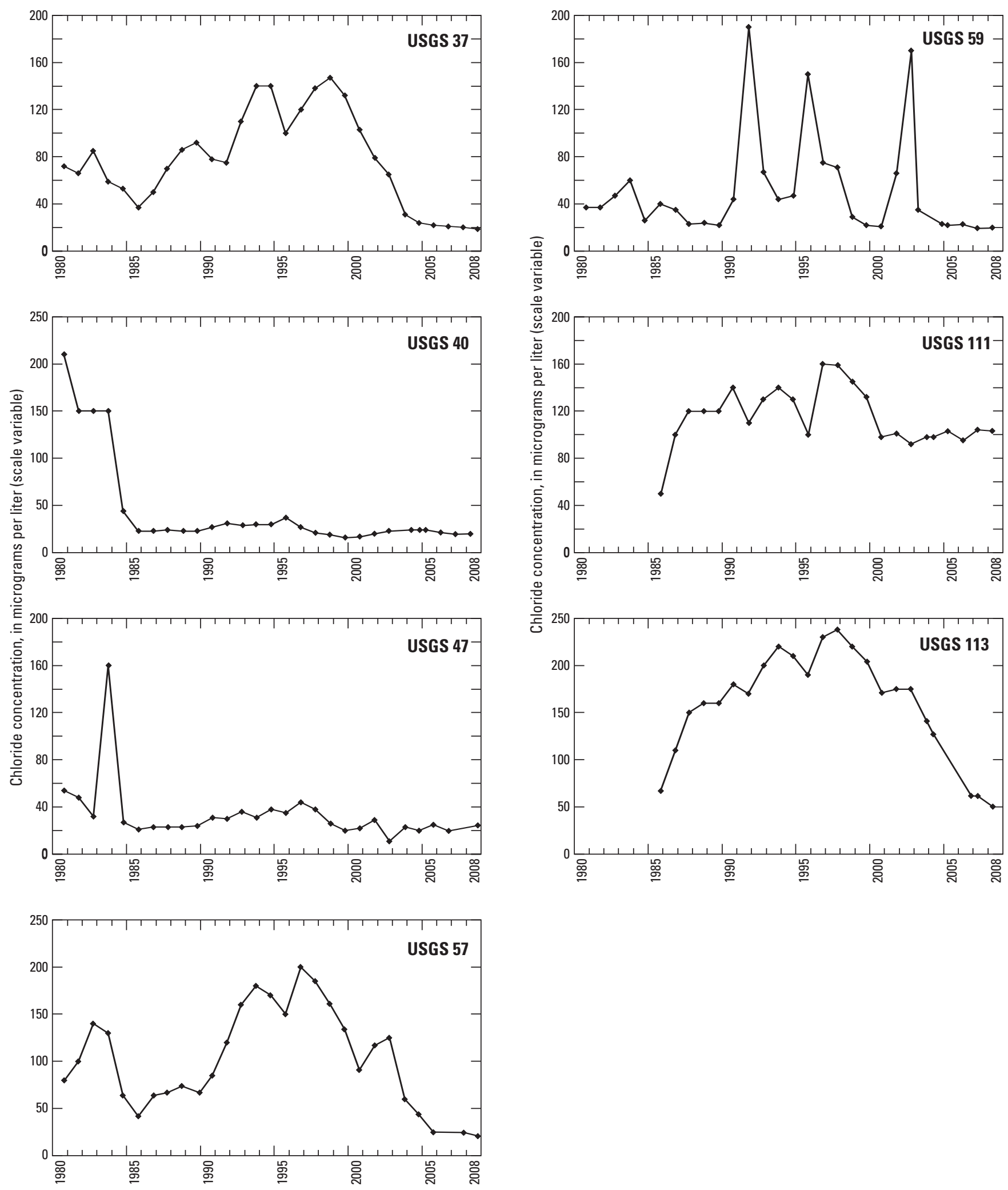

Figure 20. Dissolved chloride concentrations in water from seven wells at and near the Idaho Nuclear Technology and Engineering Center (INTEC), 1980-2008. Location of wells shown in figure 6. 
During 2002-05, concentrations decreased in some wells, but increased in others; during 2006-08, concentrations in most wells generally either were constant, or increased slightly (figs. 6 and 20). Trends in concentrations in water from wells downgradient from the percolation ponds correlated with discharge rates into the ponds when travel time was considered. For example, chloride concentrations in water from wells USGS 37 and 57 were lowest in 1985, during the period (1984-98) when the smallest amount of chloride was discharged to the ponds (fig. 21). Concentrations of chloride in water from well USGS 37 generally continued a decreasing trend through 2008. However, disposal data are not available for 1999-2008. These decreasing trends may indicate decreased disposal rates at some time prior to collection of the water samples or the redirection of discharge to the new percolation ponds to the southwest of these wells in 2002. Concentrations of chloride in water from well USGS 57 increased as discharge rates increased from 1985 through 1993; concentrations then decreased through 1995, increased in 1996, and decreased again in 1997 and 1998. Concentrations continued decreasing through October 2000, and then they increased through October 2003. Since 2003, concentrations have steadily decreased in well USGS 57 (igs. 20 and 21).

Chloride concentrations in water from well USGS 113, south of the INTEC, generally decreased from January 1998, when the concentration was $240 \mathrm{mg} / \mathrm{L}$, through October 2008, when the concentration was $50 \mathrm{mg} / \mathrm{L}$ (fig. 20). The concentration in water from well CFA 1 , also south of the INTEC, decreased in April 2006 from $114 \mathrm{mg} / \mathrm{L}$ to $88 \mathrm{mg} / \mathrm{L}$ in April 2008. Chloride concentrations in the Rifle Range well (fig. 5) increased from $9 \mathrm{mg} / \mathrm{L}$ in October 2002 to $42 \mathrm{mg} / \mathrm{L}$ in October 2008. This may be a result of discharge to the new percolation ponds southwest of INTEC beginning in 2002.

In April 2008, the chloride concentration in water from well USGS 65 south of the ATRC (fig. 6) was greater than background at $18 \mathrm{mg} / \mathrm{L}$. Chloride concentrations in water from all other wells completed in the Snake River Plain aquifer at or near the ATRC were less than background and ranged between 10 and $13 \mathrm{mg} / \mathrm{L}$ during 2008.

During 2008, chloride concentrations in water from wells USGS 88 and 89 at the RWMC were 91 and $41 \mathrm{mg} / \mathrm{L}$, respectively, nearly the same as the 2002-05 reporting period. Concentrations of chloride in all other wells near the RWMC ranged from 11 to $25 \mathrm{mg} / \mathrm{L}$.

The vertical distribution of chloride concentrations in wells equipped with Westbay ${ }^{\mathrm{TM}}$ systems varied during 2006-08 (fig. 22). The highest concentrations in water from well Middle $2050 \mathrm{~A}$ were in the uppermost and lowermost zones at about 14 to $16 \mathrm{mg} / \mathrm{L}$. Concentrations in the middle zones ranged from about 10 to $11 \mathrm{mg} / \mathrm{L}$. Concentrations in well Middle 2051 were lower in the uppermost zone (about $5.6 \mathrm{mg} / \mathrm{L}$ ) than in the deeper zones at concentrations ranging from about 10 to $12 \mathrm{mg} / \mathrm{L}$. Concentrations in water from wells USGS 103 and 132 were higher in their uppermost zone, ranging from 18 to $21 \mathrm{mg} / \mathrm{L}$ and 19 to $35 \mathrm{mg} / \mathrm{L}$, respectively. Concentrations in water from well USGS 133 generally were lower in the three upper zones and the concentration increased in the lowermost zone. Concentrations in well USGS 134 were high in the two upper zones and variable in the three lower zones. The concentrations in the two upper zones ranged from about 9 to 12 $\mathrm{mg} / \mathrm{L}$, and concentrations ranged from about 7 to $10 \mathrm{mg} / \mathrm{L}$ in the three lower zones.

\section{Sulfate}

During 1996-98, about 0.8 million $\mathrm{lb} / \mathrm{yr}$ of sulfate in wastewater was discharged at the INL, a decrease from the 1.05 million lb/yr discharged during 1992-95 (Bartholomay and others, 2000). Of the 0.8 million $\mathrm{lb} / \mathrm{yr}$ discharged during 1996-98, about $610,000 \mathrm{lb} / \mathrm{yr}$ was discharged to infiltration ponds at the ATRC, $146,000 \mathrm{lb} / \mathrm{yr}$ was discharged to percolation ponds at the INTEC, and 45,000 lb/year was discharged to the NRF industrial-waste ditch (Bartholomay and others, 2000). Background concentrations of sulfate in the Snake River Plain aquifer in the south-central part of the INL range from about 10 to $40 \mathrm{mg} / \mathrm{L}$ (Robertson and others, 1974, p. 72). Compiled data are not available for sulfate in wastewater discharged during 1999-2008. The secondary MCL for sulfate in drinking water is $250 \mathrm{mg} / \mathrm{L}$ (U.S. Environmental Protection Agency, 2001).

Because of the sulfate disposal history at the various facilities, water-sample collection for sulfate analyses at several wells was added to the USGS water-quality monitoring network in 1995. In 2008, sulfate concentrations in water samples from nine wells in the south-central part of the INL equaled or exceeded the 40-mg/L upper limit background concentration of sulfate and ranged from 40 to $157 \mathrm{mg} / \mathrm{L}$. Concentrations in water samples from MTR Test, just east of the ATRC (fig. 6), decreased from $64 \mathrm{mg} / \mathrm{L}$ in October 2001 to $23 \mathrm{mg} / \mathrm{L}$ in March 2005; and have remained constant since then. The decrease in concentrations in this well is probably a result of the discontinued use of the chemical waste ponds in 1999. Concentrations in a water sample collected during 2008 from well USGS 65, just south of the ATRC, was $157 \mathrm{mg} / \mathrm{L}$, similar to concentrations since 2001. The concentrations that are higher than background concentrations in water from these wells probably resulted from sulfate disposal at the ATRC infiltration ponds.

In April or October 2008, sulfate concentrations in water samples from USGS 88 and USGS 119 (fig. 6), near the RWMC, were 50 and $39 \mathrm{mg} / \mathrm{L}$, respectively, similar to concentrations in October 2005. The background concentration that is greater than the upper limit of $40 \mathrm{mg} / \mathrm{L}$ in water from these wells could have resulted from the well construction techniques (Pittman and others, 1988, p. 57-61). In October 2008, the sulfate concentration in well CFA 2, south of INTEC (fig. 5 ), $51 \mathrm{mg} / \mathrm{L}$, also exceeded the background concentration. This was a slight increase from the concentration in October 2005 of $42 \mathrm{mg} / \mathrm{L}$. During 2007-08, concentrations were 45, 47, and $46 \mathrm{mg} / \mathrm{L}$ in water from wells USGS 34, 35, and 39, respectively, southwest of INTEC. Historically, concentrations in these wells were equal to or just less than the upper limit background value of $40 \mathrm{mg} / \mathrm{L}$. 

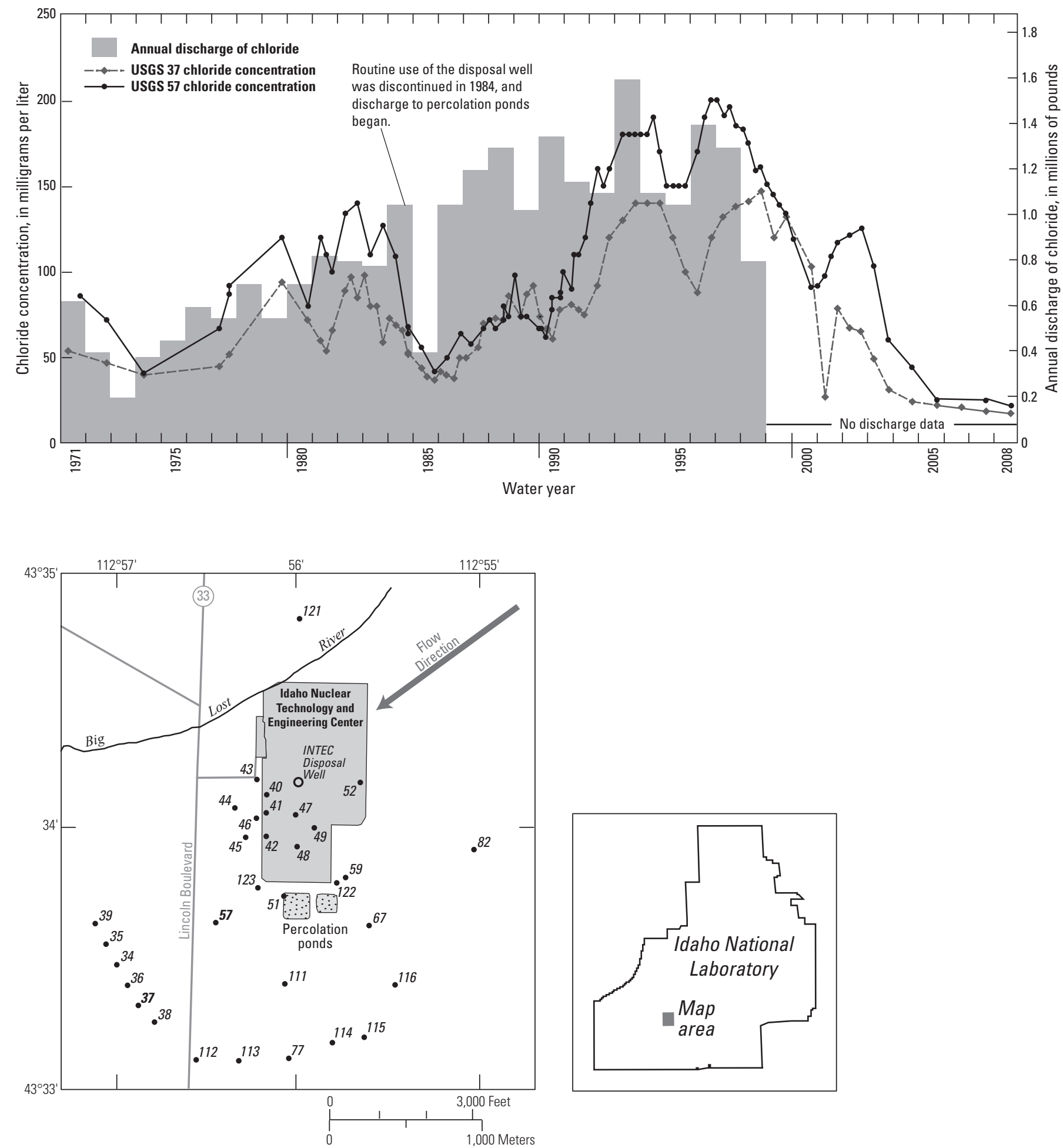

Figure 21. Amount of chloride in wastewater discharged to the disposal well and percolation ponds at the Idaho Nuclear Technology and Engineering Center (INTEC), flow direction, and the location and amount of chloride in water from wells USGS 37 and USGS 57, Idaho National Laboratory (INL), Idaho, 1971-2008. 

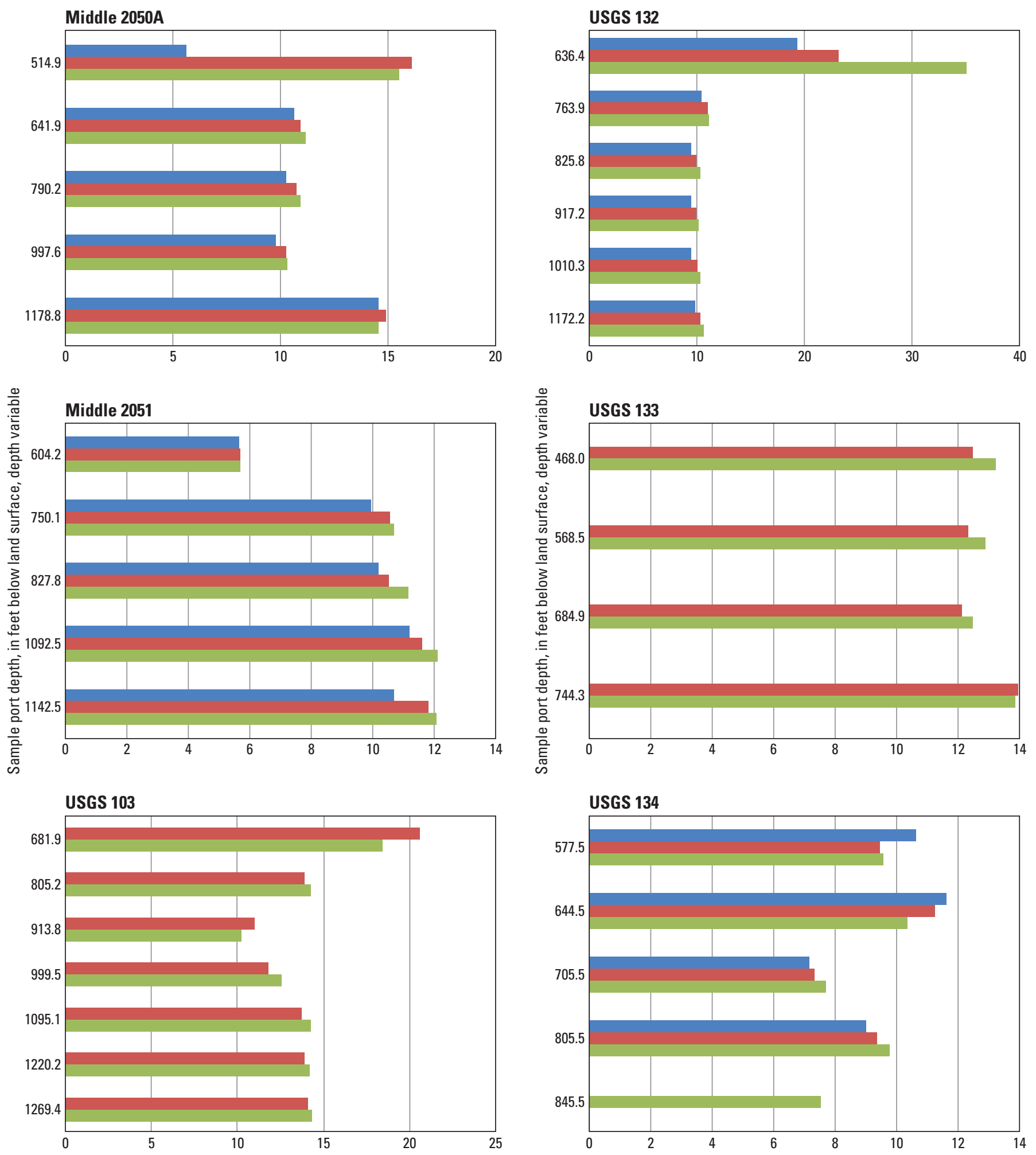

Chloride concentration, in milligrams per liter, scale variable

\section{EXPLANATION}

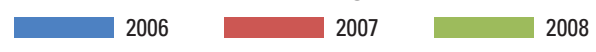

Figure 22. Vertical distribution of dissolved chloride in water from six wells equipped with multi-level Westbay ${ }^{\mathrm{TM}}$ packer sampling systems, 2006-08. 
The vertical distribution of sulfate in water from wells equipped with Westbay ${ }^{\mathrm{TM}}$ systems is shown in figure 23. During 2006-08 sulfate concentrations in water from wells Middle 2050A were highest in the uppermost zone, and lowest in the lowermost zone, with concentrations ranging from 20 to $26 \mathrm{mg} / \mathrm{L}$ and 10 to $14 \mathrm{mg} / \mathrm{L}$, respectively. Sulfate concentrations in water from wells Middle 2051, USGS 103 , and USGS 134 generally were consistent with depth that ranged from about 20 to $27 \mathrm{mg} / \mathrm{L}, 19$ to $26 \mathrm{mg} / \mathrm{L}$, and 16 to $21 \mathrm{mg} / \mathrm{L}$, respectively. Sulfate concentrations were highest in water from well USGS 132 in the uppermost zone, with concentrations ranging from 39 to $41 \mathrm{mg} / \mathrm{L}$. Sulfate concentrations in the lower five zones in this well were consistent with depth and ranged from 23 to $26 \mathrm{mg} / \mathrm{L}$. Sulfate concentrations in water from well USGS 133 were slightly variable in the two middle zones during 2007-08. Concentrations throughout all zones ranged from about 19 to $22 \mathrm{mg} / \mathrm{L}$.

\section{Nitrate (as N)}

Wastewater containing nitrate was injected into the Snake River Plain aquifer through the INTEC disposal well from 1952 to February 1984 and was discharged to the INTEC percolation ponds after February 1984 (Orr and Cecil, 1991). About 260,000 lb of nitrate was discharged to the INTEC percolation ponds during 1996-98, 220,000 lb of which was discharged during February 1996 (Bartholomay and others, 2000). Discharge rates of nitrate for 1999-2008 are not available. Concentrations of nitrate in groundwater not affected by wastewater disposal from INL facilities generally are less than $1 \mathrm{mg} / \mathrm{L}$ (as N) (Robertson and others, 1974, p. 73).

Concentrations of nitrate in this report are reported as nitrogen $(\mathrm{N})$, a change from previous publications in which nitrate was reported as nitrate. To convert concentrations as $\mathrm{N}$ to concentrations as $\mathrm{NO}_{3}{ }^{-}$, the nitrate (as $\mathrm{N}$ ) concentration should be multiplied by 4.4266 (Hem, 1989, table 8 ) so that concentrations reported here can be compared with those given in previous reporting-period publications. Historical nitrite analyses indicate that almost all nitrite plus nitrate concentrations in water are nitrate at and near the INL; the nitrite concentrations are almost always less than the LRL for analyses performed by NWQL.

All nitrate (as N) concentrations measured in 2008 were less than the MCL for drinking water of $10 \mathrm{mg} / \mathrm{L}$ (as N) (U.S. Environmental Protection Agency, 2001). Nitrate concentrations at the INL have changed in response to reduced disposal rates and to the transition in 1984 from injection of wastewater to the INTEC disposal well to discharge to percolation ponds. In 1981, the maximum nitrate (as N) concentration for wells near the INTEC was $14 \mathrm{mg} / \mathrm{L}$ in water from well USGS 43 at the INTEC just west of the INTEC Disposal well (Lewis and Jensen, 1985) (figs. 6 and 24), and exceeded the MCL. Nitrate concentrations in water from wells in the vicinity of the INTEC disposal well and percolation ponds (wells USGS 40, 41, 43, 47, 48, 51, 52, and 67) have been variable through time (fig. 24). The variability could have resulted from periodic dilution by recharge from the Big Lost River and variation in discharge rates to the injection well prior to 1984 or percolation ponds later. Concentrations of nitrate (as N) in wells south of INTEC and further away from the influence of disposal areas and the Big Lost River [wells USGS 77, 111, 113, 114, 116, and CFA 1 (figs. 5 and 6)] show much less variability and a general decrease in nitrate (as N) concentrations through time (fig. 25). In October 2008, concentrations of nitrate (as $\mathrm{N}$ ) in water from most wells at and near the INTEC (wells USGS 40, 41, 47, 48, 51, 52, 67, $77,111,113,114,116)$ exceeded the background concentration of $1 \mathrm{mg} / \mathrm{L}$. Concentrations ranged from $2.2 \mathrm{mg} / \mathrm{L}$ (as N) in well USGS 113 to $5.97 \mathrm{mg} / \mathrm{L}$ (as N) in well USGS 47.

Historically, nitrate (as N) concentrations in water from wells near the RWMC have slightly exceeded the regional background concentration of about $1 \mathrm{mg} / \mathrm{L}$ as N (Robertson and others, 1974). In 1998, nitrate (as N) concentrations in water samples from wells USGS 88, 89, and 119, near the RWMC, exceeded the background and were 1.6, 2.0, and $1.4 \mathrm{mg} / \mathrm{L}($ as N), respectively (Bartholomay and others, 2000). Since 1998, the concentrations of nitrate (as N) in water from wells USGS 88, 89, and 119 remained relatively unchanged, with concentrations in 2008 of $0.9,1.7$, and $1.4 \mathrm{mg} / \mathrm{L}$ (as N), respectively. In 2005, near the ATRC, the concentration of nitrate (as N) in water from well USGS 65 was $1.6 \mathrm{mg} / \mathrm{L}$, and remained constant in 2008 with a concentration of $1.5 \mathrm{mg} / \mathrm{L}$. Figure 26 shows the generalized distribution of nitrate (as N) concentrations in water samples collected in April or October 2008.

Figure 27 shows the vertical distribution of nitrate concentrations(as $\mathrm{N}$ ) with depth in Westbay ${ }^{\mathrm{TM}}$ equipped wells during 2006-08. The vertical distribution of nitrate (as N) in wells Middle 2051, USGS 103, and USGS 133, showed similar patterns. Nitrate concentrations (as N) in all three of these wells were lower in the uppermost zone, and similar in all deeper zones in each well (fig. 27). Concentrations of nitrate (as N) from all zones in Middle 2051 and USGS 103 were less than $1 \mathrm{mg} / \mathrm{L}$. Concentrations in the deepest zone in well USGS 133 were slightly higher at about $1.2 \mathrm{mg} / \mathrm{L}$. Nitrate (as N) concentrations in water from well USGS 132 were higher in the upper zone than concentrations found in the deeper zones. Concentrations of nitrate (as N) in water from well Middle 2050A varied throughout the vertical sampling column (fig. 27), but concentrations generally were less than $1 \mathrm{mg} / \mathrm{L}$. In well USGS 134, concentrations of nitrate (as N) were variable between zones and all were less than $1 \mathrm{mg} / \mathrm{L}$ (fig. 27). 

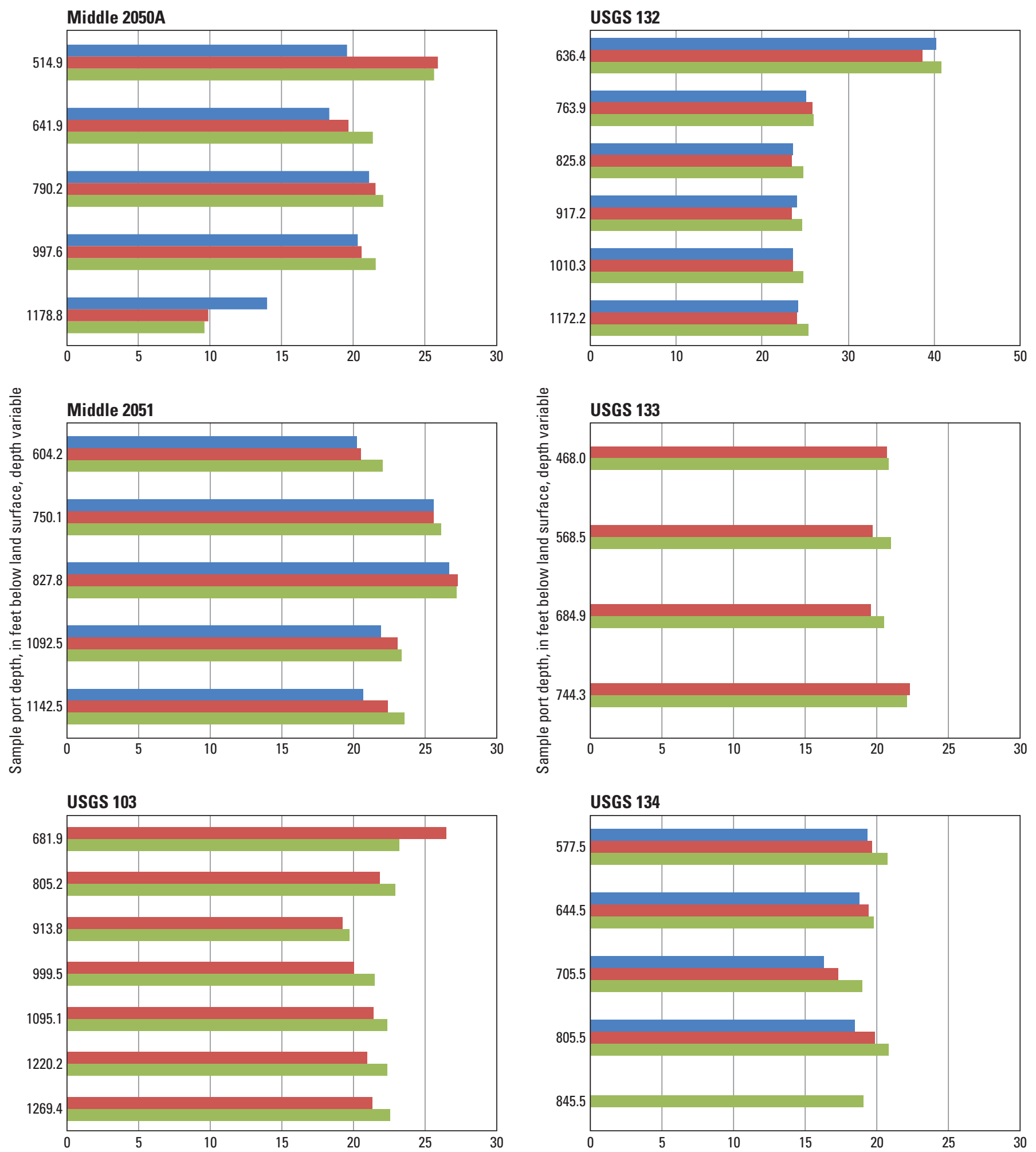

Sulfate concentration, in milligrams per liter, scale variable

\section{EXPLANATION}

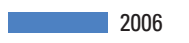

\section{7}

Figure 23. Vertical distribution of dissolved sulfate in water from six wells (Middle 2050A, Middle 2051, USGS 103, 132, 133, and 134) equipped with multi-level Westbay ${ }^{\mathrm{TM}}$ packer sampling systems, 2006-08. 

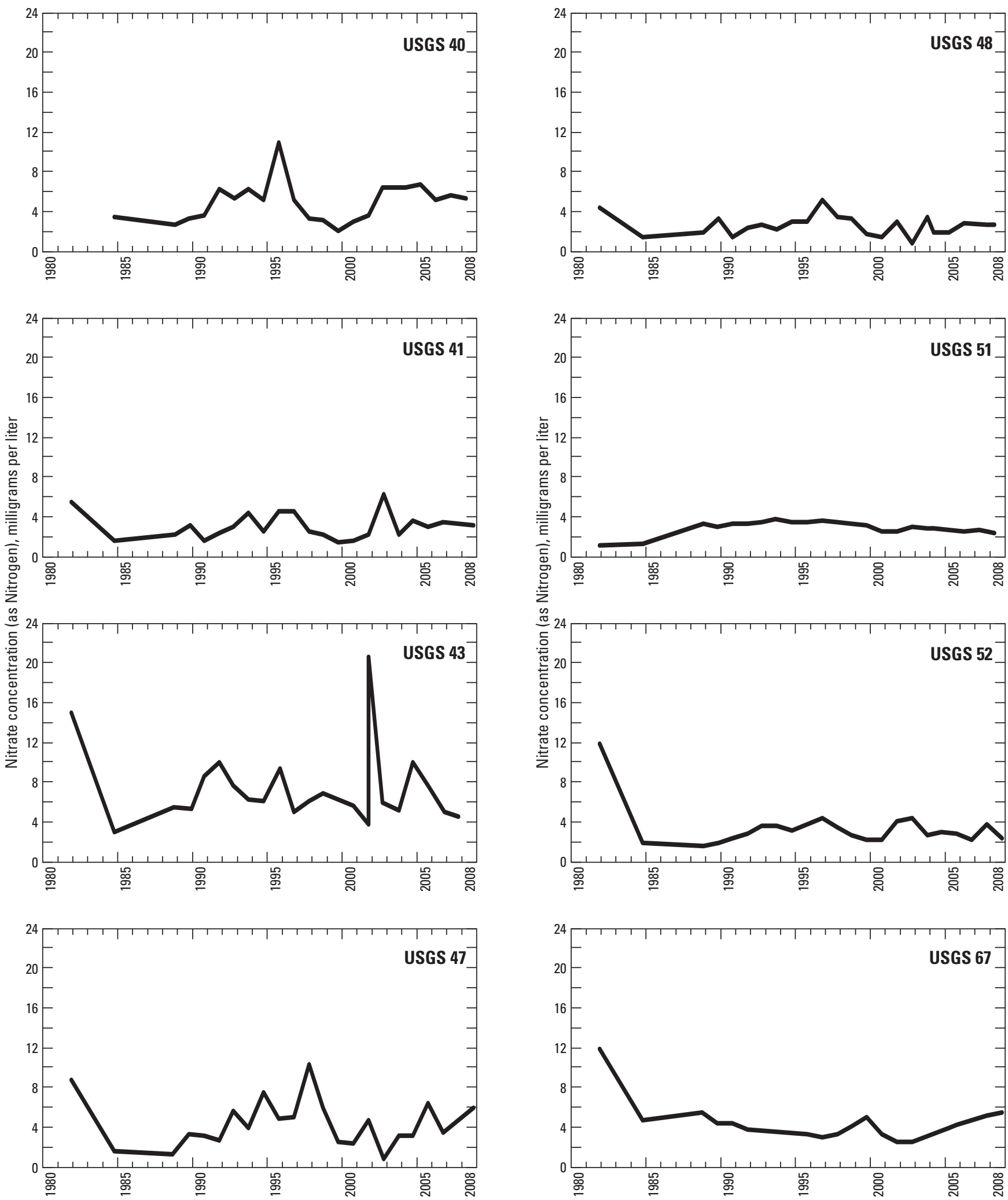

Figure 24. Concentration of nitrate (as $\mathrm{N}$ ) in water from wells at and near the Idaho Nuclear Technology and Engineering Center (INTEC), 1981-2008. 

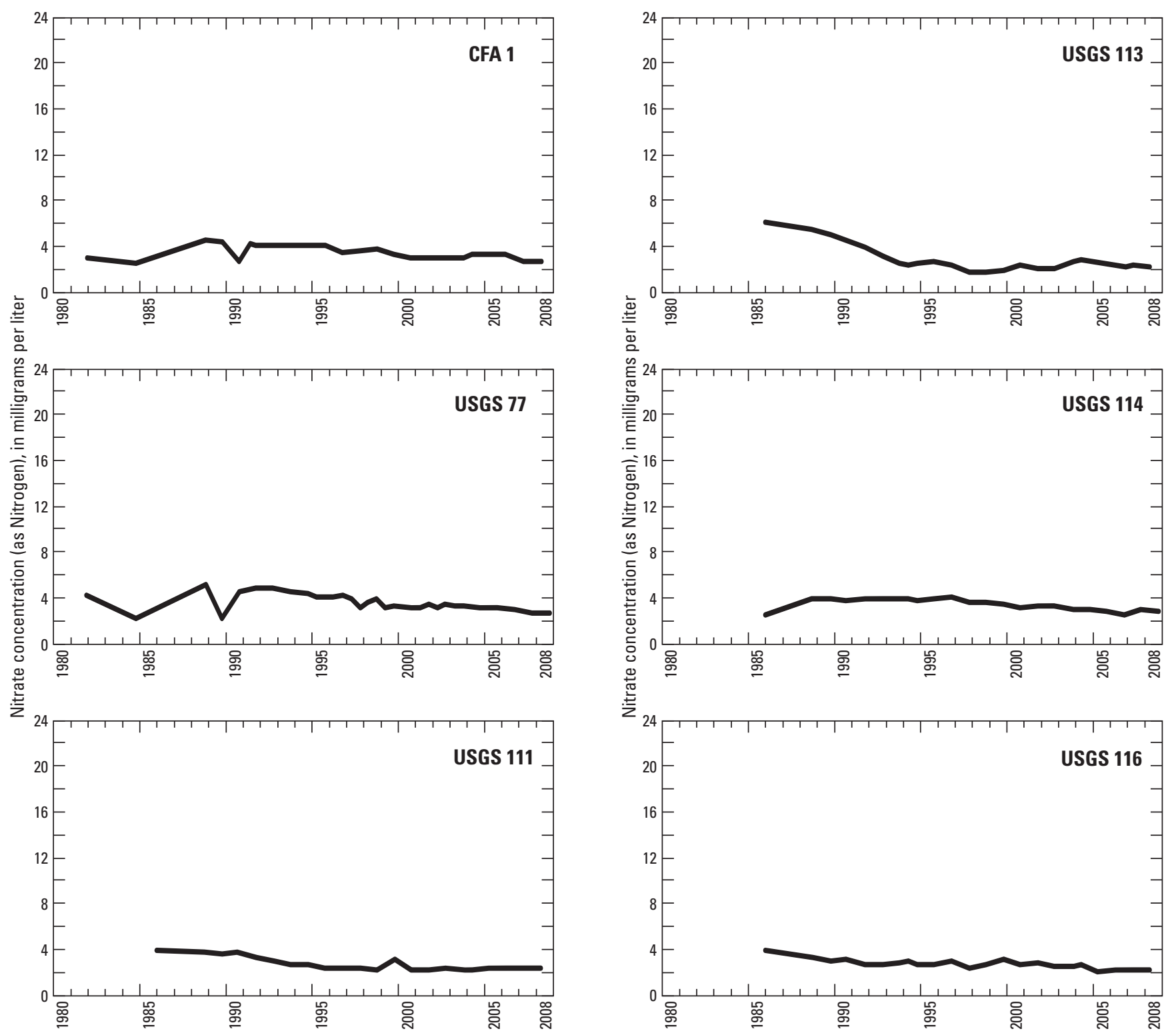

Figure 25. Concentration of nitrate (as N) in water from wells south of the Idaho Nuclear Technology and Engineering Center (INTEC), 1981-2008. 


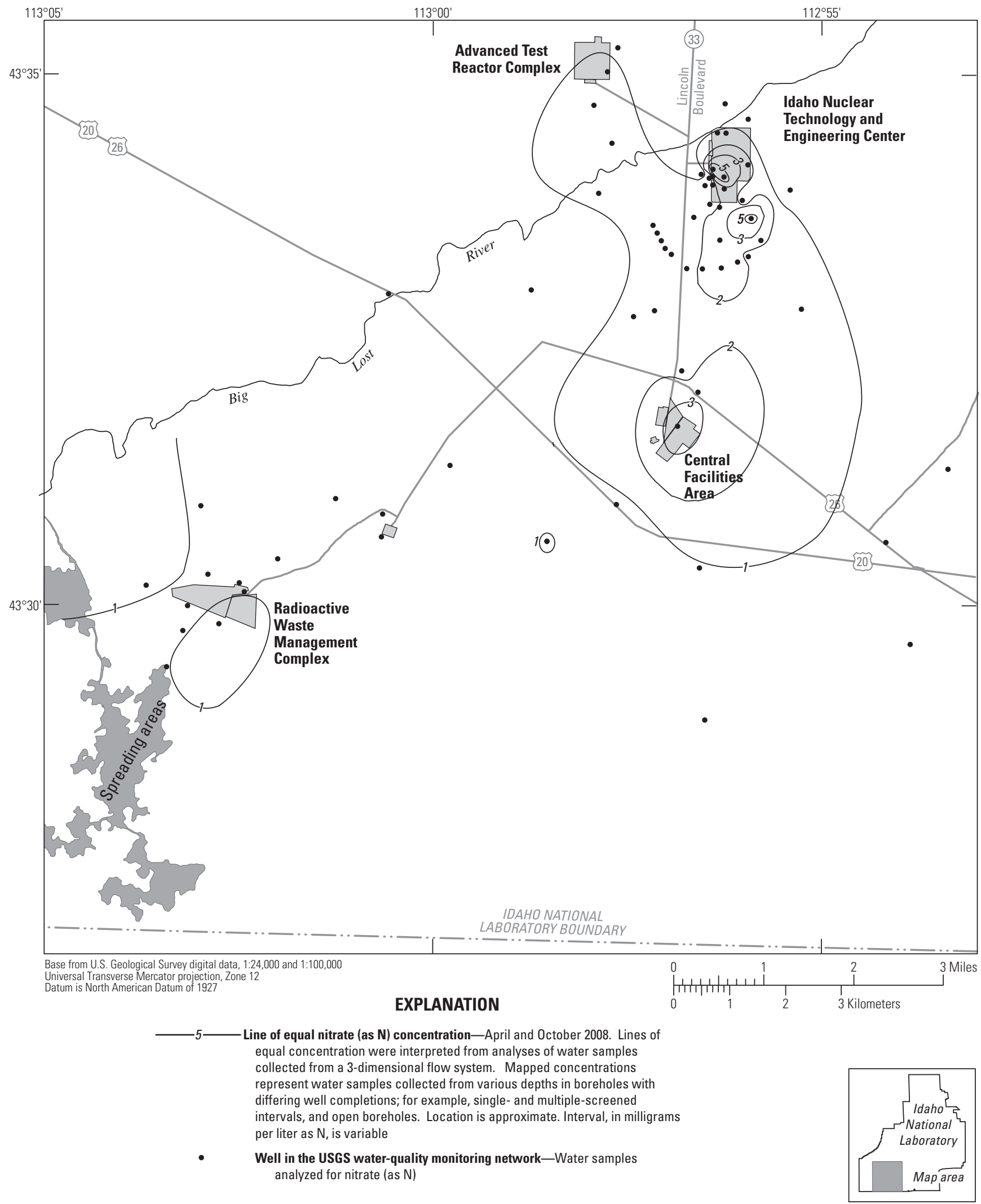

Figure 26. Distribution of nitrate (as N) in water from wells at and near the Advanced Test Reactor Complex (ATRC), Idaho Nuclear Technology and Engineering Center (INTEC), Central Facilities Area (CFA), and Radioactive Waste Management Complex (RWMC), Idaho National Laboratory (INL), Idaho, April or October 2008. 

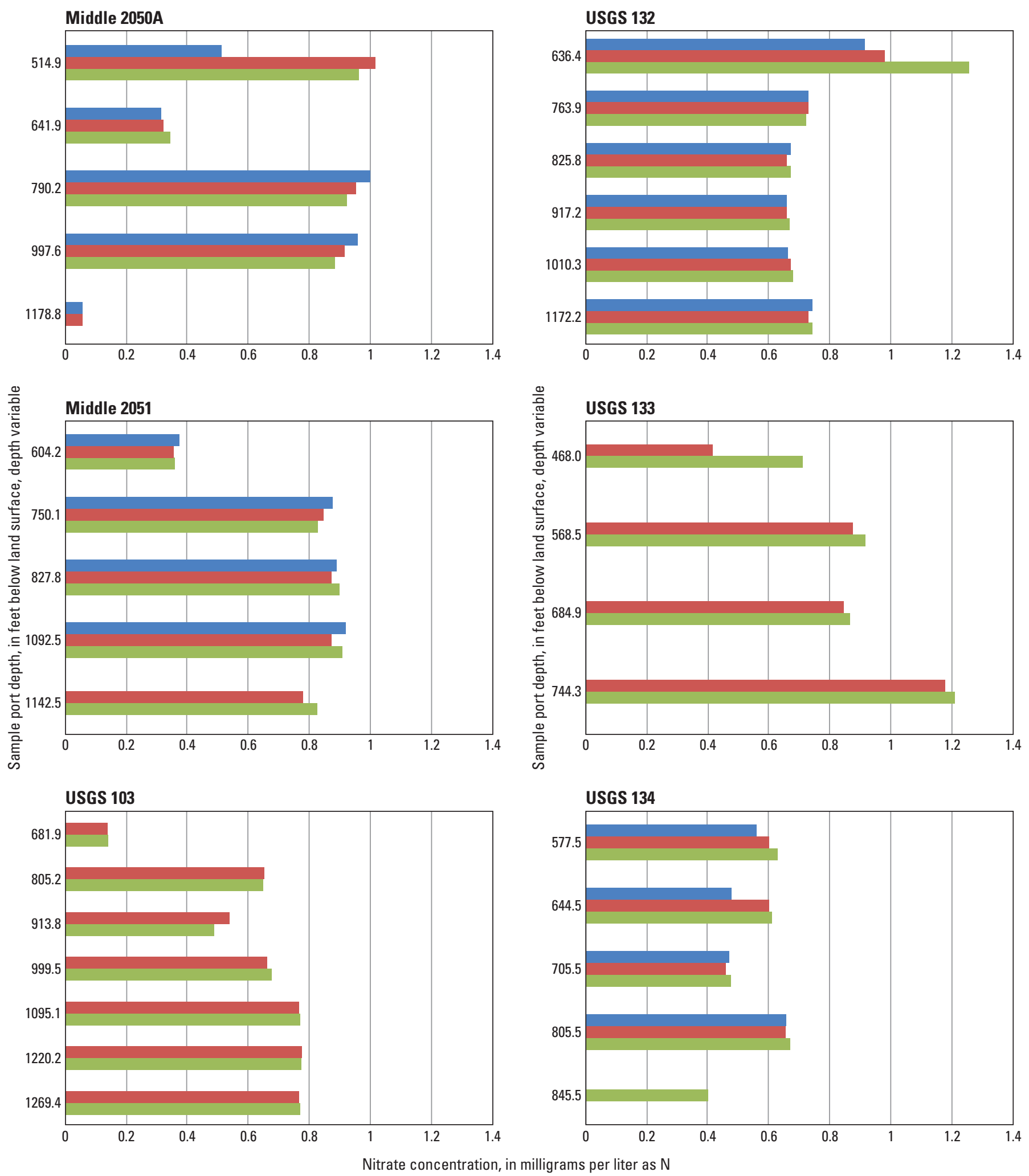

EXPLANATION

Figure 27. Vertical distribution of nitrate (as $\mathrm{N}$ ) in water from six wells equipped with multi-level Westbay ${ }^{\top \mathrm{M}}$ packer sampling systems, 2006-08. 


\section{Fluoride}

About $39,710 \mathrm{lb}$ of fluoride in wastewater was discharged to percolation ponds at the INTEC during 1971-98 (Bartholomay and others, 2000). Background concentrations of fluoride in the Snake River Plain aquifer in the southwestern part of the INL range from about 0.1 to $0.3 \mathrm{mg} / \mathrm{L}$ (Robertson and others, 1974, p. 75). Amounts of fluoride discharged since 1998 have not been compiled.

As part of the INL groundwater monitoring program adopted in 1994, the USGS began analyzing water samples collected near the INTEC for concentrations of fluoride. During April or October 2008, water samples from four wells (CPP 1, USGS 34, 38, and 77, fig. 6) were analyzed for fluoride; detected concentrations ranged from 0.2 to $0.3 \mathrm{mg} / \mathrm{L}$. These concentrations are similar to the background concentrations reported by Robertson and others (1974), which indicates that wastewater disposal has not had an appreciable effect on fluoride concentrations in the Snake River Plain aquifer near the INTEC. The LRL for fluoride ranged from 0.08 to $0.12 \mathrm{mg} / \mathrm{L}$ during 2006-08.

Fluoride concentrations in water samples collected from all but two zones from wells equipped with Westbay ${ }^{\mathrm{TM}}$ multi-level sampling systems during 2006-08 were within the range of background concentrations reported by Robertson and others (1974) (fig. 28). Fluoride concentrations in the two uppermost zones of well USGS 103 ranged from about 0.32 to $0.47 \mathrm{mg} / \mathrm{L}$. Concentrations in the rest of the lower zones in USGS 103 were consistent, with concentrations of about 0.21 $\mathrm{mg} / \mathrm{L}$. Fluoride concentrations in the uppermost zones of wells USGS 132, 133, 134, and Middle 2051 were slightly higher than in deeper zones, but all concentrations were less than $0.3 \mathrm{mg} / \mathrm{L}$. The highest concentration of fluoride in well Middle 2050A was in the deepest zone, although the concentration also was less than $0.3 \mathrm{mg} / \mathrm{L}$ (fig. 28).

\section{Trace Elements}

As part of the INL groundwater monitoring program adopted in 1994 and several special sampling programs, water samples from several wells were collected and analyzed for various trace elements during 2006-08. These trace elements were aluminum, antimony, arsenic, barium, beryllium, cadmium, cobalt, copper, iron, lead, lithium, manganese, mercury, molybdenum, nickel, selenium, silver, strontium, thallium, uranium, vanadium, and zinc. A summary of background concentrations of selected constituents in Snake River Plain aquifer water samples is presented in Knobel and others (1992, p. 52). Because the amounts of each constituent in wastewater discharged from INL facilities have not been compiled annually from monitoring data since 1998, these amounts are unavailable for 1999-2008.
Beginning in 1998, NWQL began implementing new reporting procedures based on long-term method detection levels (LT-MDLs) for some analytical methods (Childress and others, 1999). This change in LRLs (as opposed to MRLs) for some elements accounts for concentrations of some elements detected during 1999-2008, although historically the concentrations were less than the MRL. Table 6 presents a summary of disposal data, disposal periods, and trace element concentration ranges in water samples analyzed during $2006-08$ by the USGS. Bartholomay and Twining (2010, table 5) give a comprehensive summary of the vertical distribution of selected trace elements for each of the six wells equipped with multi-level Westbay ${ }^{\mathrm{TM}}$ packer sampling systems.

\section{Volatile Organic Compounds}

Volatile organic compounds (VOCs) are present in water from the Snake River Plain aquifer because of wastedisposal practices at the INL. From 1987-2005, water samples from many wells completed in the Snake River Plain aquifer at and near the INL were analyzed for VOCs for various water quality studies (Mann and Knobel, 1987; Mann, 1990; Liszewski and Mann, 1992; Greene and Tucker, 1998; Bartholomay and others, 2000; Davis, 2006b, 2008). Analyses from these studies indicated that from 1 to 19 VOCs in water samples from several wells exceeded their reporting levels during these years. The primary VOCs detected included carbon tetrachloride; 1,1-dichloroethane; 1,1,1-trichloroethane; trichloroethylene; tetrachloroethylene; chloroform; and toluene. During 2006-08, water samples from 30 wells were collected and analyzed for VOCs. Twelve VOCs were detected. One to 10 VOCs were detected in water samples from 11 wells.

A plume of 1,1,1-trichloroethane, a solvent used in industrial cleaning processes (Lucius and others, 1989, p. 450), has developed in the Snake River Plain aquifer near the INTEC because of waste-disposal practices (Bartholomay and others, 1995). During 1992-95, water samples were collected from 10 wells near the INTEC that previously contained water with concentrations of 1,1,1-trichloroethane exceeding the MRL. Concentrations in water from 8 of the 10 wells exceeded the MRL (Bartholomay and others, 1997). During 1996-98, water samples were collected from three wells near INTEC that previously contained water with concentrations of 1,1,1-trichloroethane exceeding the MRL; concentrations in water from all three of the wells exceeded the MRL.

During 2006-08, concentrations of 1,1,1-trichloroethane in water from wells USGS 34,38 , and 77, south of the INTEC, and well USGS 65, south of the ATRC (fig. 6), exceeded the MRL as during the 2002-05 reporting period. 

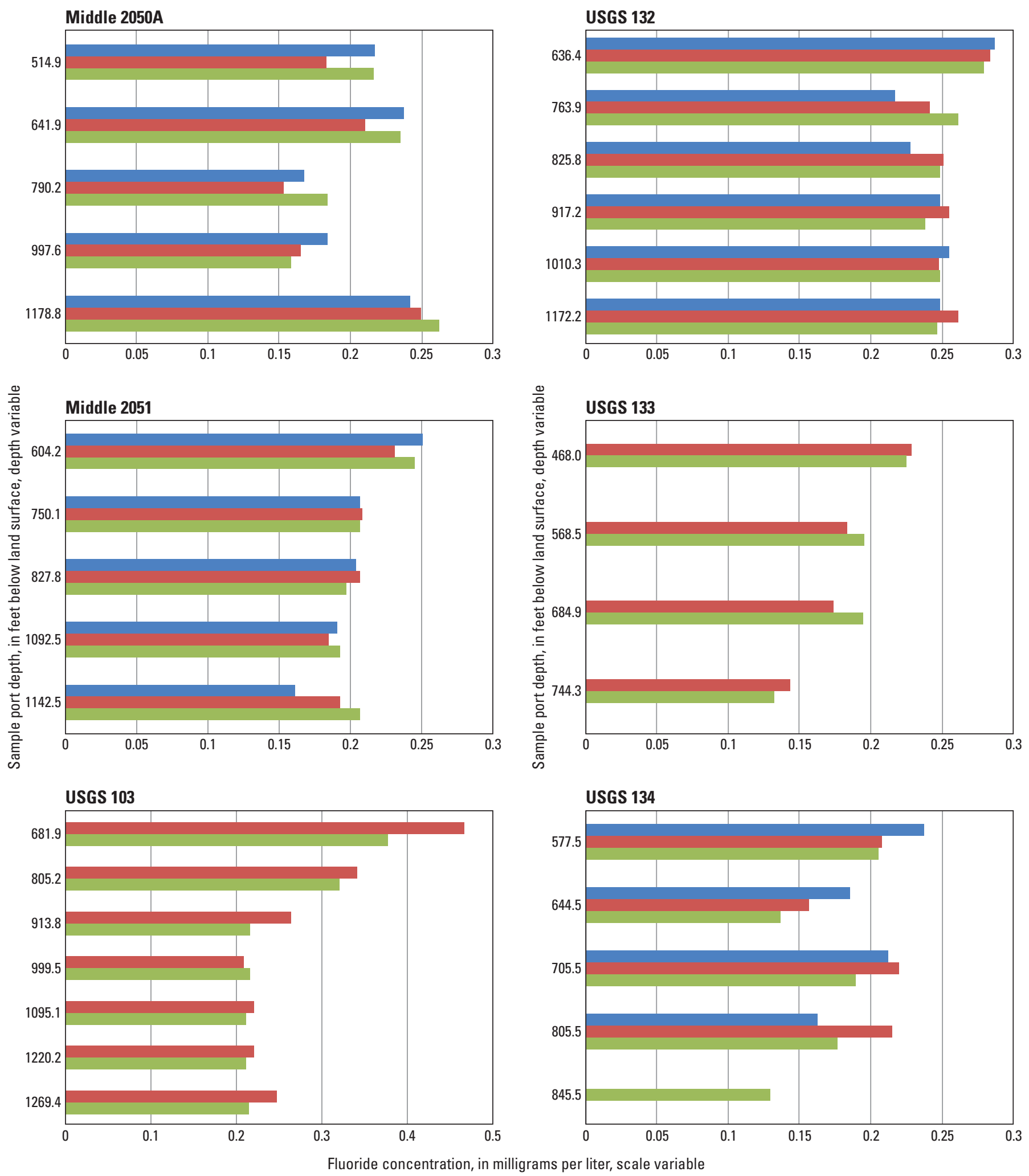

EXPLANATION

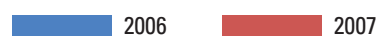

Figure 28. Vertical distribution of fluoride in water from six wells (Middle 2050A, Middle 2051, USGS 103, 132, 133, and 134) equipped with multi-level Westbay ${ }^{\mathrm{TM}}$ packer sampling systems, 2006-08. 
Table 6. Trace elements disposed during various periods, number of wells sampled, and range of concentrations detected, Idaho National Laboratory, Idaho, 2006-08.

[Because the amounts of each constituent in wastewater discharged from INL facilities have not been compiled annually from monitoring data since 1998, no amounts are available for 1999-2008. Amount disposed, disposal period, and disposal facility from Bartholomay and others, 2000. Abbreviations: LRL, Laboratory Reporting Level; NR, none recorded; ND, not detected; INL, Idaho National Laboratory; INTEC, Idaho Nuclear Technology and Engineering Center; lb, pound; $\mu \mathrm{g} / \mathrm{L}$, microgram per liter. Symbol: $<$, less than]

\begin{tabular}{|c|c|c|c|c|c|c|}
\hline Constituent & $\begin{array}{l}\text { Approximate } \\
\text { amount } \\
\text { disposed } \\
\text { (Ib) }\end{array}$ & $\begin{array}{c}\text { Disposal } \\
\text { period }\end{array}$ & $\begin{array}{l}\text { Disposal } \\
\text { facility }\end{array}$ & $\begin{array}{l}\text { Number of wells } \\
\text { sampled at } \\
\text { the INL during } \\
\text { 2006-08 }\end{array}$ & $\begin{array}{c}\text { Range of } \\
\text { concentrations } \\
(\mu \mathrm{g} / \mathrm{L})\end{array}$ & $\begin{array}{c}\text { LRL(s) used } \\
\text { during 2006-08 } \\
(\mu \mathrm{g} / \mathrm{L})\end{array}$ \\
\hline Aluminum & 117 & 1995-98 & INTEC & 16 & $1.67-29.04$ & $1.6,4$ \\
\hline Antimony & NR & NR & INL & 15 & $0.072-0.39$ & $0.2,0.06,0.14,0.04$ \\
\hline Arsenic & 11 & 1971-98 & INL & 15 & $0.74-3.26$ & $0.12,0.06$ \\
\hline Cadmium & 22 & $1971-98$ & INL & 16 & $0.04-0.37$ & $0.04,0.02,2.0,0.06$ \\
\hline Cobalt & NR & NR & INL & 16 & $0.02-2.36$ & $0.4,0.02,2,1.4$ \\
\hline Copper & 81 & 1995-98 & INTEC & 16 & $0.41-5.25$ & $0.4,1,2$ \\
\hline Iron & 752 & 1995-98 & INTEC & 6 & $15.95-25.03$ & $6,8,4$ \\
\hline Lead & 556 & 1971-98 & INL & 16 & $0.1-3.21$ & $0.08,0.12,0.06$ \\
\hline Nickel & NR & NR & INL & 16 & $0.12-4.16$ & $0.06,0.2,0.12$ \\
\hline Selenium & 9 & 1971-98 & INL & 10 & $0.61-2.07$ & $0.08,0.04,0.12$ \\
\hline Silver & 190 & 1971-98 & INL & 16 & ND & $0.008,0.1,0.20$ \\
\hline Strontium (stable) & NR & NR & INL & 6 & 200.9-305.9 & $0.4,0.8$ \\
\hline Thallium & NR & NR & INL & 10 & ND & 0.04 \\
\hline Uranium & NR & NR & INL & 15 & $0.45-2.68$ & $0.04,0.02,0.006$ \\
\hline Vanadium & NR & NR & INL & 6 & $0.07-6.36$ & $0.04,0.16$ \\
\hline Zinc & 5,240 & 1971-98 & INL & 16 & $0.77-330.98$ & $0.6,1.8,2$ \\
\hline
\end{tabular}

The concentrations in water from wells USGS 34 and 38 were both $0.17 \mu \mathrm{g} / \mathrm{L}$, a slight increase from the 2004-05 concentrations of 0.10 and $0.11 \mu \mathrm{g} / \mathrm{L}$, respectively. The concentrations in water in wells USGS 65 and 77 were 0.10 and $0.13 \mu \mathrm{g} / \mathrm{L}$, respectively, in 2008, a slight decrease from the concentrations of 0.14 and $0.2 \mu \mathrm{g} / \mathrm{L}$, respectively, from the 2002-05 reporting period. The MRL for 1,1,1-trichloroethane varied between 0.1 and $1.0 \mu \mathrm{g} / \mathrm{L}$ during 2006-08. All 1,1,1-trichloroethane concentrations were less than the MCL for drinking water of $200 \mu \mathrm{g} / \mathrm{L}$ (U.S. Environmental Protection Agency, 2001). In October 2006, the concentration of 1,1-dichloroethylene in water from well USGS 77 was $0.16 \mu \mathrm{g} / \mathrm{L}$, but was not detected during 2007-08. In April 2008, water from well USGS 65 contained toluene with a concentration of $0.25 \mu \mathrm{g} / \mathrm{L}$.

Historically, concentrations of VOCs in water samples from several wells at and near the RWMC exceeded the reporting levels (Bartholomay and others, 2000). For example, in October 1998, water from the RWMC Production Well contained $4.5 \mu \mathrm{g} / \mathrm{L}$ of carbon tetrachloride, $0.8 \mu \mathrm{g} / \mathrm{L}$ of chloroform, $0.5 \mu \mathrm{g} / \mathrm{L}$ of 1,1,1-trichloroethane, $2.1 \mu \mathrm{g} / \mathrm{L}$ of trichloroethylene, and $0.18 \mu \mathrm{g} / \mathrm{L}$ of tetrachloroethylene. In December 2005, nine VOCs were detected, and in December 2008, five VOCs were detected in water from the RWMC Production Well. Reported concentrations in 2008 were $8.5 \mu \mathrm{g} / \mathrm{L}$ of carbon tetrachloride, $1.5 \mu \mathrm{g} / \mathrm{L}$ of trichloromethane, $0.54 \mu \mathrm{g} / \mathrm{L}$ of 1,1,1-trichloroethane, $3.1 \mu \mathrm{g} / \mathrm{L}$ of trichloroethylene, and $0.32 \mu \mathrm{g} / \mathrm{L}$ of tetrachloroethylene. Chloroform was not detected in 2008 although it was detected in 2005. The concentration of carbon tetrachloride was higher in December 2008 than the concentration in December 2005 of $6.3 \mu \mathrm{g} / \mathrm{L}$. A plot of carbon tetrachloride concentrations in water from the RWMC Production Well (fig. 29) indicates that concentration trends have increased with time from about 1 to $8 \mu \mathrm{g} / \mathrm{L}$ since 1967. 


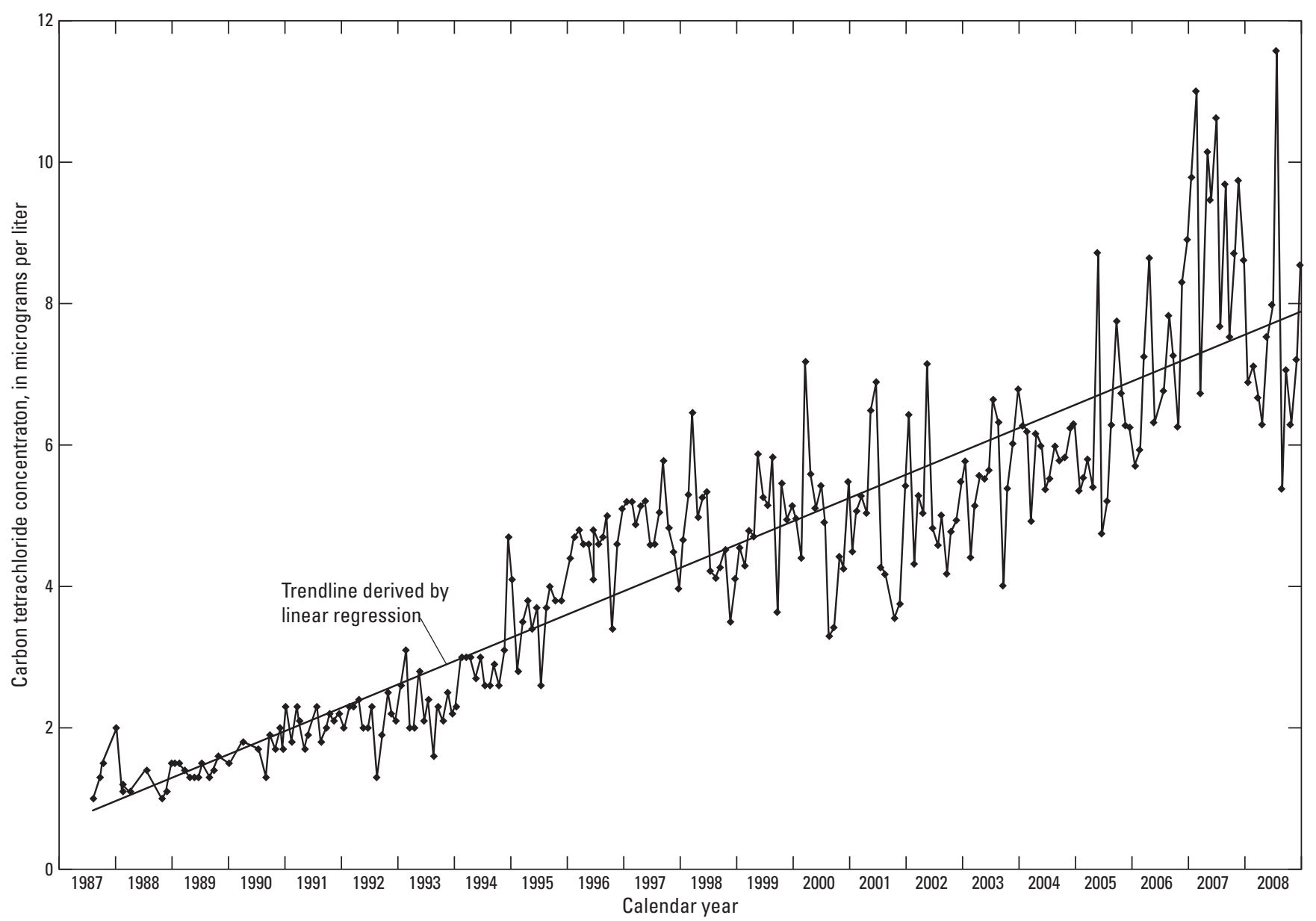

Figure 29. Carbon tetrachloride concentrations in water from the Radioactive Waste Management Complex (RWMC) Production Well, Idaho National Laboratory (INL), Idaho, 1987-2008.

In April 2008, VOCs were detected in three wells near the RWMC (fig. 6). Concentrations of carbon tetrachloride, 1,1,1-trichloroethane, trichloromethane, trichloroethylene, and tetrachloroethylene in water from well USGS 87 exceeded the reporting levels. In October 2008, concentrations of carbon tetrachloride, trichloroethylene, and trichloromethane in water from well USGS 88 also exceeded the reporting levels, as did concentrations of carbon tetrachloride, 1,1,1-trichloroethane, trichloroethylene, and trichloromethane in water from well
USGS 120. During 2006-08, water samples from three wells near TAN (ANP 9, No Name 1, and PSTF Test) (fig. 2) were sampled for VOCs. Concentrations of VOCs in water from these wells were all less than the MRL. Chloroform had been detected in all three wells during 2002-05, but was not detected during 2006-08. Historically, concentrations of from 1 to 15 VOCs in water from wells near TAN exceeded the MRL (Davis, 2008). 


\section{Total Organic Carbon}

Analyses of TOC are used to screen for organic compounds in the aquifer as a general indicator of groundwater contamination. As part of the INL groundwater monitoring program adopted in 1994, the USGS began collecting and analyzing water from several wells at the INL for TOC. During April or October 2008, water samples from 50 wells completed in the Snake River Plain aquifer at the INL were analyzed for TOC; detected concentrations ranged from 0.43 to $1.9 \mathrm{mg} / \mathrm{L}$. The LRL for TOC ranged between 0.4 and $0.6 \mathrm{mg} / \mathrm{L}$ during 2008 .

Water samples were collected and analyzed for total organic carbon from six wells equipped with multi-level Westbay $^{\mathrm{TM}}$ samplings systems. Results showed that the concentrations were variable between zones sampled in each well (Bartholomay and Twining, 2010). Bartholomay and Twining (2010) gives a comprehensive summary of concentrations in each zone in each well.

\section{Specific Conductance, Temperature, and pH}

Specific conductance is a measure of the electrical conductivity of water and is proportional to the quantities of dissolved chemical constituents in the water. Dissolved chemical constituents such as chloride, sodium, and sulfate in wastewater discharged to disposal wells and infiltration ponds at INL facilities generally have increased the specific conductance of groundwater through time.

In 2008, the specific conductance of water from 135 wells ranged from 223 to $2,220 \mu \mathrm{S} / \mathrm{cm}$; the highest value was in water from well NRF 6 located near the NRF waste ditch. Specific conductance measurements for water from most wells around the NRF area was around 500-600 $\mu \mathrm{S} / \mathrm{cm}$ (fig. 30).

The general increase in specific conductance in groundwater attributed to wastewater discharged to the aquifer since the mid-1980s is apparent in groundwater downgradient from INL facilities. A plume of increased specific conductance originated from the INTEC percolation ponds (fig. 6) and extended downgradient from the INTEC to the CFA (fig. 30). The specific conductance of water from several wells within this plume increased from about $500 \mu \mathrm{S} / \mathrm{cm}$ in 1985 (Pittman and others, 1988, p. 64) to more than $1,000 \mu \mathrm{S} / \mathrm{cm}$ in 1998 , but decreased to about $802 \mu \mathrm{S} / \mathrm{cm}$ by 2008 in water from well USGS 51. This decreasing trend in wells downgradient of INL facilities continued during 2006-08.
The specific conductance of water from several wells at the ATRC exceeded $400 \mu \mathrm{S} / \mathrm{cm}$ in 2005. Specific conductance of water from well USGS 65 (fig. 6), downgradient from the infiltration ponds at the ATRC, was $607 \mu \mathrm{S} / \mathrm{cm}$ in April 2005 and $612 \mu \mathrm{S} / \mathrm{cm}$ in April 2008.

At the CFA, the specific conductance of water from well CFA 1 decreased from $700 \mu \mathrm{S} / \mathrm{cm}$ in 2006 to $609 \mu \mathrm{S} / \mathrm{cm}$ in 2008; and in well CFA 2, the measurements increased from $784 \mu \mathrm{S} / \mathrm{cm}$ in 2006 to $810 \mu \mathrm{S} / \mathrm{cm}$ in 2008 .

The maximum specific conductance measured in water from well USGS 88, near the RWMC, was $580 \mu \mathrm{S} / \mathrm{cm}$ in October 2008, a slight increase from the measurement of $570 \mu \mathrm{S} / \mathrm{cm}$ in October 2005.

Water temperature and $\mathrm{pH}$ were measured annually during 2006, 2007, and 2008 in water from 124, 127, and 127 wells at the INL, respectively. The lowest water temperatures consistently were measured in well $\mathrm{P} \& \mathrm{~W} 2$, northwest of the TAN (fig. 5) and ranged from 8.3 to $9.0^{\circ} \mathrm{C}$, a slight increase from the 2002-05 reporting period (Davis, 2008). The highest water temperatures consistently were measured in well USGS 7, ranging from 19.3 to $19.5^{\circ} \mathrm{C}$. The median water temperature for all wells sampled annually from 2006 to 2008 , was $12.7,12.8$, and $12.7^{\circ} \mathrm{C}$, respectively, a slight decrease from the 2002-05 reporting period when the median was $12.9,12.8,12.8$, and 12.9 , respectively for each year.

In 2006, pH ranged from 7.1 in well USGS 82 east of the INTEC to 8.5 in well USGS 119 south of the RWMC (fig. 6). In 2007, pH ranged from 7.3 in water from well USGS 29 on the eastern border of the INL (fig. 5) to 9.0 in water from well USGS 119, south of the RWMC (fig. 6). In 2008, pH ranged from 7.4 in water from well USGS 4 on the eastern border of the INL (fig. 5) to 9.1 in water from well USGS 119 (fig. 6). The median $\mathrm{pH}$ in water from all wells annually from 2006 to 2008 was $7.8,7.9$, and 7.8 , respectively, similar to the $2002-05$ reporting period when median $\mathrm{pH}$ ranged from 7.6 to 8.0 .

Field measurements of water temperature, $\mathrm{pH}$, and specific conductance were made in all wells equipped with Westbay ${ }^{\mathrm{TM}}$ sampling systems during 2006-08. Bartholomay and Twining (2010, table 2) compiled field measurements taken from these wells during 2006-08. 


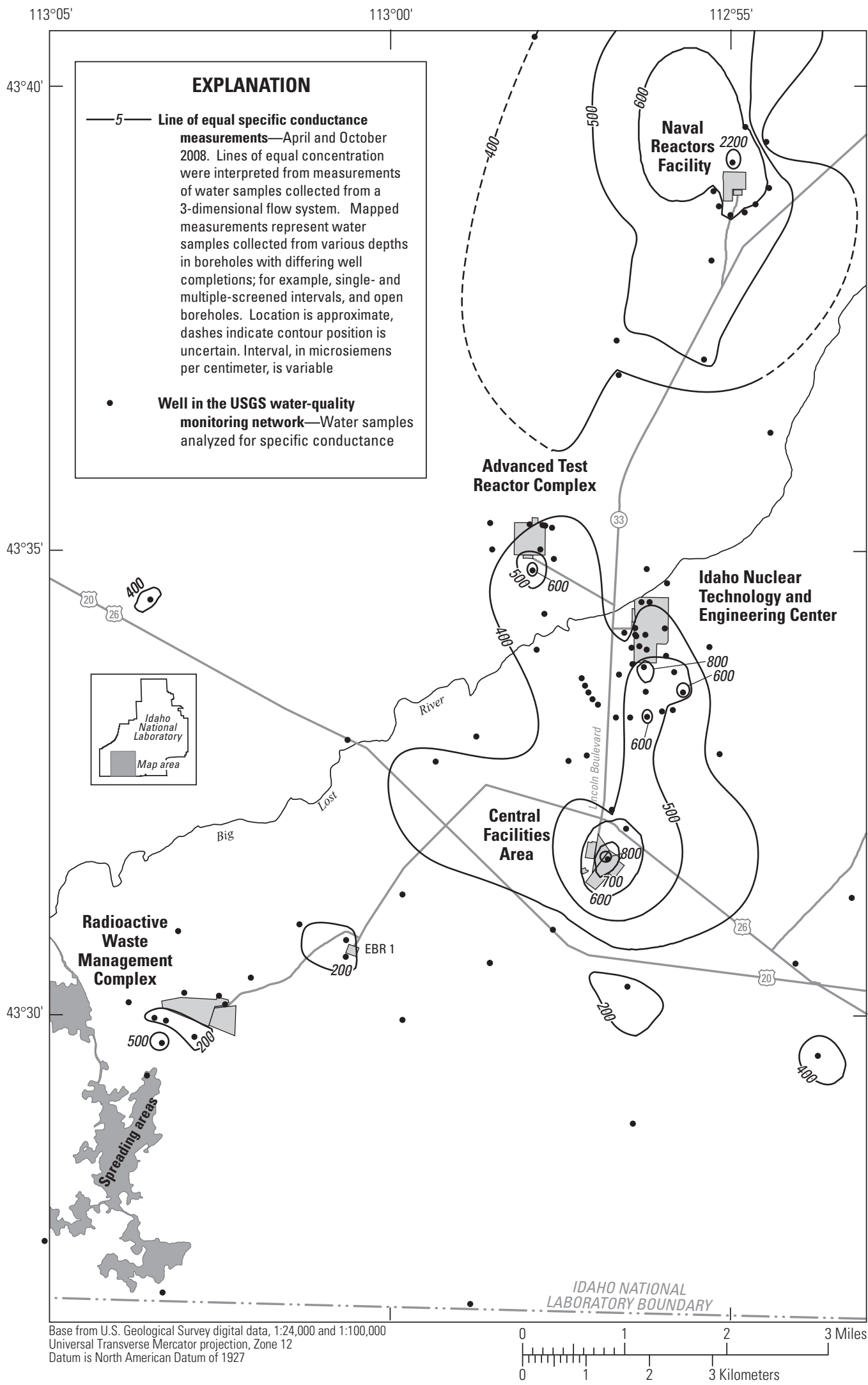

Figure 30. Distribution of specific conductance of water from wells at and near the Advanced Test Reactor Complex (ATRC), Naval Reactors Facility (NRF), and Idaho Nuclear Technology and Engineering Center (INTEC), Central Facilities Area (CFA), and Radioactive Waste Management Complex (RWMC), Idaho National Laboratory (INL), Idaho, April or October 2008. 


\section{Selected Radiochemical and Chemical Constituents and Physical Properties of Water in Perched Groundwater}

Disposal of wastewater to infiltration ponds and ditches, lined evaporation ponds, drain fields, and infiltration of surface water at waste-burial pits resulted in formation of perched groundwater in basalts and in sedimentary interbeds that overlie the Snake River Plain aquifer. Perched groundwater has formed in a complex sequence of basalt flow and sedimentary interbeds beneath the ATRC, the INTEC, and the RWMC. Anderson and Lewis (1989) and Anderson (1991) correlated geophysical logs to describe the stratigraphic sequences in which perched groundwater has formed. Although the subsurface stratigraphy, geohydrologic characteristics, and waste disposal practices at each of these areas differ, the features controlling the formation of perched groundwater at these sites are similar (Cecil and others, 1991). Sedimentary interbeds in the subsurface may have smaller vertical hydraulic conductivities than overlying basalt flows, and alteration between basalt flows may contribute to reduced vertical hydraulic conductivity in the interflow rubble zones. Dense, unfractured basalt flows may have a decreased vertical hydraulic conductivity and inhibit downward flow, and sedimentary or chemical infilling of fractures in basalt may reduce vertical hydraulic conductivity by limiting the interconnectivity of fractures, reducing the water-transmitting capability of the basalts (Cecil and others, 1991). Any combination of these factors may disrupt the downward movement of water and contribute to the formation of perched groundwater zones.

Wastewater-disposal sites at INL facilities are the primary sources of radiochemical and chemical constituents in perched groundwater at the INL. During 2006-08, wastewater was discharged to infiltration and lined-evaporation ponds. Davis (2008) provides detailed information on waste disposal amounts and types of constituents discharged at each facility through 1998. Data for amounts and types of constituents discharged have not been compiled for 1998-2008.

\section{Advanced Test Reactor Complex}

Bodies of shallow and deep perched groundwater formed at the ATRC in response to wastewater disposal into radioactive-, chemical-, cold-, and sanitary-waste ponds (Tucker and Orr, 1998) (fig. 6). Radiochemical and chemical constituents in wastewater migrate to the Snake River Plain aquifer through perched groundwater beneath these wastewater infiltration ponds. The extent of perched groundwater is affected by the waste-disposal practices. Selected radiochemical and inorganic chemical constituents in wastewater have been monitored in the shallow and deep perched groundwater since the early 1960s.
Water samples from three wells (CWP 1, 3, and 8) completed in shallow perched groundwater near the ATRC (fig. 7) routinely were collected and analyzed for selected radiochemical and chemical constituents during 2006-08. Wells USGS 53, TRA A 13, and TRA A 77 were scheduled to be sampled, but were dry during the scheduled sampling runs; therefore, samples could not be collected. Water samples were collected from 17 wells (PW 8, 9, USGS 54 through 56, 60 through $63,66,68$ through 73 , and 78) that were completed in deep perched groundwater beneath the ATRC. Sampling was discontinued at many perched groundwater wells during the 2002-05 reporting period because of lack of water in the wells (Davis, 2008, fig. 21). Selection of radiochemical and chemical constituents for analyses was based on wastedisposal history at the ATRC. Selected radiochemical constituents were tritium, strontium-90, and gamma analyses (which may yield detections of cesium-137, cobalt-60, or chromium-51); chemical constituents were dissolved chromium, sodium, chloride, and sulfate.

\section{Tritium}

The concentration of tritium in perched groundwater near the ATRC during April or October 2008 is shown in figure 31. Concentrations of tritium in wells near the ATRC historically have been high compared to 2008 values. The decrease in tritium concentrations in perched groundwater from wells near the ATRC likely is a result of changes in wastewater disposal practices near those wells. In some cases, the change in disposal practices also may have led to a decrease in the amount of perched groundwater available to sample.

Well TRA A 77 (fig. 7) is completed in shallow perched groundwater in alluvium near the ATRC retention basin, where radioactive wastewater flowed before discharge to the radioactive-waste ponds. Some wastewater reportedly leaked to the subsurface through cracks in the retention basin (U.S. Department of Energy, 1991, p. 29). To prevent discharge of radioactive wastewater to the retention basin, the retention basin was isolated in 1993 when discharge to the lined evaporation ponds began (Bartholomay and Tucker, 2000). The highest tritium concentration in water from well TRA A 77 was 3,940,000 $\pm 60,000 \mathrm{pCi} / \mathrm{L}$ in 1992 (Bartholomay, 1998, p. 41). By April 1997 the concentrations had decreased to $1,000 \pm 150 \mathrm{pCi} / \mathrm{L}$ (Bartholomay, 1998, table 2). Historically, tritium concentrations varied in water from well TRA A 77. Because of the shallow depth of well TRA A 77 and its proximity to the leaking retention basin, the variability in tritium concentrations in this well could have resulted from changes in tritium disposal rates (Bartholomay, 1998, p. 10). Water samples have not been collected from well TRA A 77 since April 1997 because water was not present in the well during scheduled sampling dates. The lack of water in this well may be the result of discontinued use of the retention basin for transfer of radioactive wastewater. 


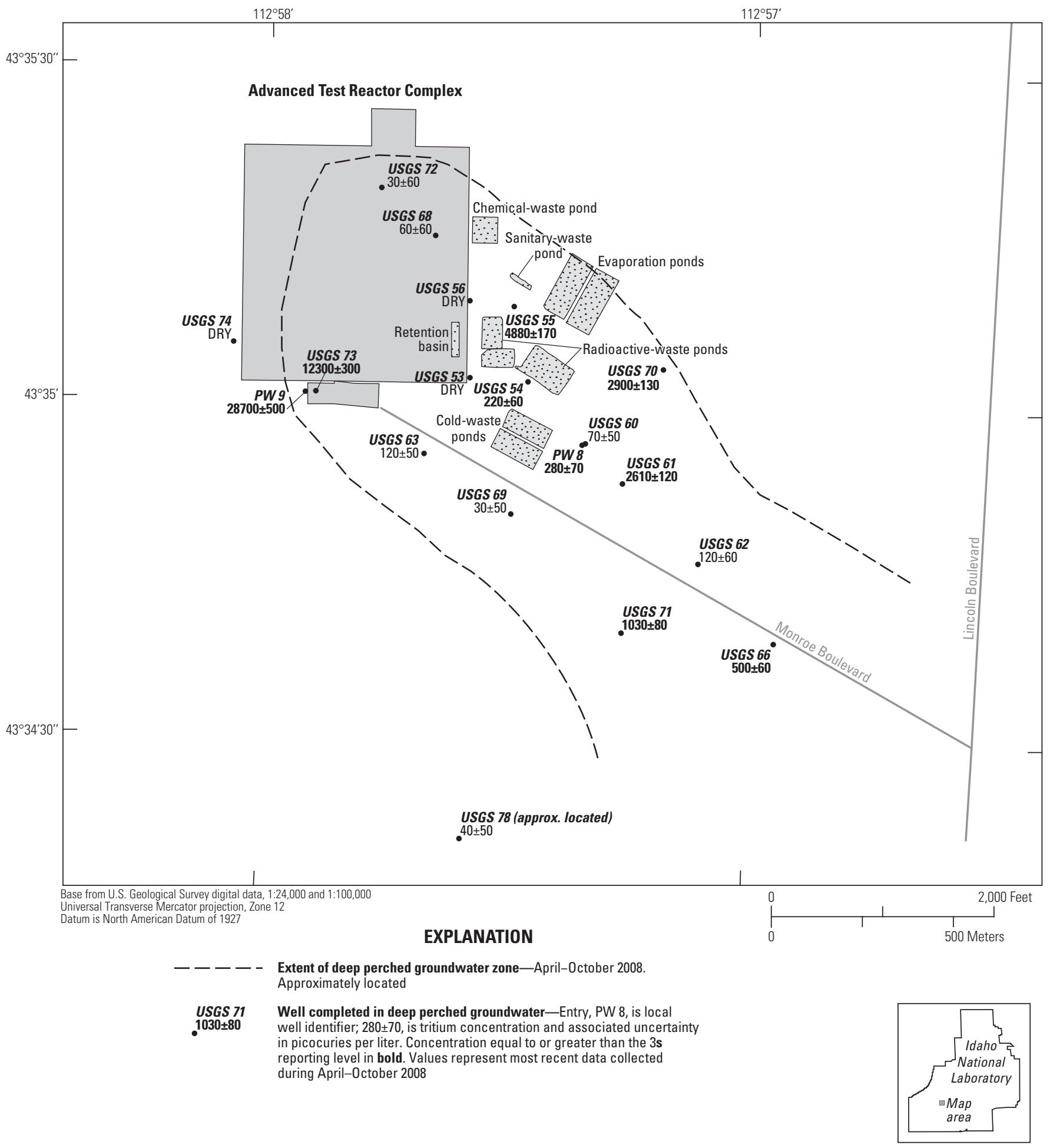

Figure 31. Concentrations of tritium in water from wells completed in deep perched groundwater, Advanced Test Reactor Complex, Idaho National Laboratory, Idaho, April or October 2008. 
Maximum concentrations of tritium in water from well TRA A 13 (fig. 7) decreased from $158,000 \pm 2,000 \mathrm{pCi} / \mathrm{L}$ during $1982-85$ to $1,100 \pm 300 \mathrm{pCi} / \mathrm{L}$ during $1986-88$ (Cecil and others, 1991, p. 33); during 1989-2001, tritium concentrations in water from this well were less than the reporting level. The decrease in tritium concentrations in well TRA A 13, between the radioactive-waste infiltration ponds and the cold-waste ponds (fig. 31), likely can be attributed to the large quantity of nonradioactive water discharged to the cold-waste ponds (Bartholomay and Tucker, 2000). Water samples were not collected from this well after April 2001 because of well obstructions or because the well was dry during scheduled sampling events and sampling this well has been discontinued for the USGS water-quality sampling program.

Wells CWP 1 through CWP 9 (fig. 4) monitor shallow perched groundwater around the cold-waste ponds at the ATRC. During 2006-08, tritium concentrations in water samples collected from wells CWP 1, 3, and 8 were less than the reporting level.

Discharge of cooling-tower wastewater to the TRA disposal well ceased in 1982, and this water subsequently was discharged to the cold-waste ponds. During 1982-2005, tritium was less than the reporting level in water from wells CWP 1 through CWP 7. A tritium concentration of $800 \pm 200 \mathrm{pCi} / \mathrm{L}$ was measured in water from well CWP 8 in November 1988; since then, concentrations have been less than the reporting level. Tritium concentrations in water from well CWP 9 decreased from $6,300 \pm 200 \mathrm{pCi} / \mathrm{L}$ during 1982-85 to $1,100 \pm 200 \mathrm{pCi} / \mathrm{L}$ during $1986-88$ (Cecil and others, 1991 , p. 35). Water samples have not been collected from CWP 9 since 1988. The absence of detectable tritium concentrations in most CWP wells was attributed to the large quantity of nonradioactive wastewater discharged to the cold-waste ponds since 1982 which has diluted any residual radioactive-waste infiltration pond water (Bartholomay and Tucker, 2000). Lack of available perched groundwater to sample and the history of non-reportable values of tritium in most of these wells resulted in the decision to remove wells CWP 2, 4, 5, 6, 7, and 9 from the sampling schedule at various times during 2002-05.

Tritium concentrations in water from 11 wells completed in deep perched groundwater (PW 8, PW 9, USGS 55, 54, $56,61,63,66,70,71$, and 73 ) generally were greater than the reporting level during at least one sampling event during 2006-08 (table 7). Tritium concentrations in water from six wells (USGS 60, 62, 68, 69, 72, and 78) were less than the reporting level during 2006-08 (table 7).

During April or October 2008, tritium concentrations in water from 10 wells completed in deep perched groundwater at the ATRC exceeded the reporting levels (table 7). Tritium concentrations ranged from $280 \pm 70 \mathrm{pCi} / \mathrm{L}$ in water from well PW 8 to $28,700 \pm 500 \mathrm{pCi} / \mathrm{L}$ in water from well PW 9 (fig. 31).

Water samples collected in October 2008 from wells USGS 73 and PW 9 contained tritium concentrations of $13,100 \pm 300$ and $28,700 \pm 500 \mathrm{pCi} / \mathrm{L}$, respectively. Concentrations of tritium in these two wells have decreased significantly since October 1993 when concentrations were
$296,000 \pm 10,000 \mathrm{pCi} / \mathrm{L}$ in water from well USGS 73 and $193,000 \pm 6,000 \mathrm{pCi} / \mathrm{L}$ in water from well PW 9 . Water from well USGS 74 (fig. 31) contained 93,100 $\pm 1,700 \mathrm{pCi} / \mathrm{L}$ of tritium in April 1992; however, water samples have not been collected since 1992 because the well was dry and was removed from the sampling schedule in October 2001. These three wells are located more than $1,500 \mathrm{ft}$ west of the radioactive-waste infiltration ponds (fig. 31). In 1993, the radioactive-waste infiltration ponds were taken out of service and wastewater was discharged to lined evaporation ponds (Davis, 2008). Historically high tritium concentrations in water from these wells indicate that the chemistry of perched groundwater west of the ATRC was affected by radioactive-waste infiltration pond disposals. Discontinuation of wastewater discharge to the radioactive-waste infiltration ponds and the subsequent use of lined evaporation ponds, together with the radioactive decay process, may account for the decreased tritium concentrations in this area from 1993-2008 and could indicate an eastward migration of the extent of deep perched groundwater relative to well USGS 74.

Bartholomay (1998) determined that increases in tritium concentrations in water from wells USGS 53, 56, and 70 corresponded partly to tritium disposal rates. The hydraulic connection between the radioactive-waste infiltration ponds and wells USGS 53 and 56 also can be demonstrated because well USGS 53 dried up and the water level in well USGS 56 declined below the pump intake subsequent to cessation of wastewater disposal to the ponds. Water was present and water samples were collected from well USGS 53 in October 2003. The concentration of tritium in well USGS 53 was greater than the reporting level at $3,100 \pm 200 \mathrm{pCi} / \mathrm{L}$; however, the decrease in concentration was significant compared to the concentration of $126,000 \pm 4,000 \mathrm{pCi} / \mathrm{L}$ for the water sample analyzed in October 1995. Water samples also were collected from well USGS 56 in October 2004 and 2005, with concentrations greater than the reporting level at 23,300 \pm 900 and $23,300 \pm 1,100 \mathrm{pCi} / \mathrm{L}$, respectively. The tritium concentration in a sample collected from water from well USGS 56 in October 2006 was $9,490 \pm 330 \mathrm{pCi} / \mathrm{L}$, less than one-half of the October 2005 concentration. The decreases in concentrations were significant compared to the concentration of $148,000 \pm 5,000 \mathrm{pCi} / \mathrm{L}$ for the last water sample analyzed in April 1997.

Several factors affected the distribution of tritium in perched groundwater at the ATRC, including proximity of wells to the radioactive-waste infiltration ponds, depth of water below the ponds, variations in tritium disposal rate, and radioactive decay. Since 1982, tritium concentrations also have been affected by dilution from the cold-waste ponds. Replacement of the radioactive-waste infiltration ponds with the lined evaporation ponds in 1993 contributed to decreases in tritium concentrations in perched groundwater and decreases in perched groundwater in some wells. Infiltration from the Big Lost River during 1999, early 2000, 2005, and 2006 may have contributed to diluted tritium concentrations in perched groundwater southeast of the ATRC. 
Table 7. Concentrations of tritium, strontium-90, and cesium-137 in perched groundwater from selected wells, Advanced Test Reactor Complex, Idaho National Laboratory, Idaho, 2006-08.

[Well No.: Locations of wells are shown in figure 7. Analyses completed by the Department of Energy's Radiological and Environmental Sciences Laboratory. Analytical uncertainties are reported as 1 times the sample standard deviation. Concentrations equal to or greater than 3 times the sample standard deviation are considered to be greater than the reporting level and are bold. Abbreviations: DP, well completed in deep perched groundwater; SP, well completed in shallow perched groundwater; NR, analysis not requested; NS-DRY, not sampled because the well was dry; NSEQ, not sampled because of equipment problems; pCi/L, picocurie per liter; USGS, U.S. Geological Survey. Symbol: \pm , plus or minus]

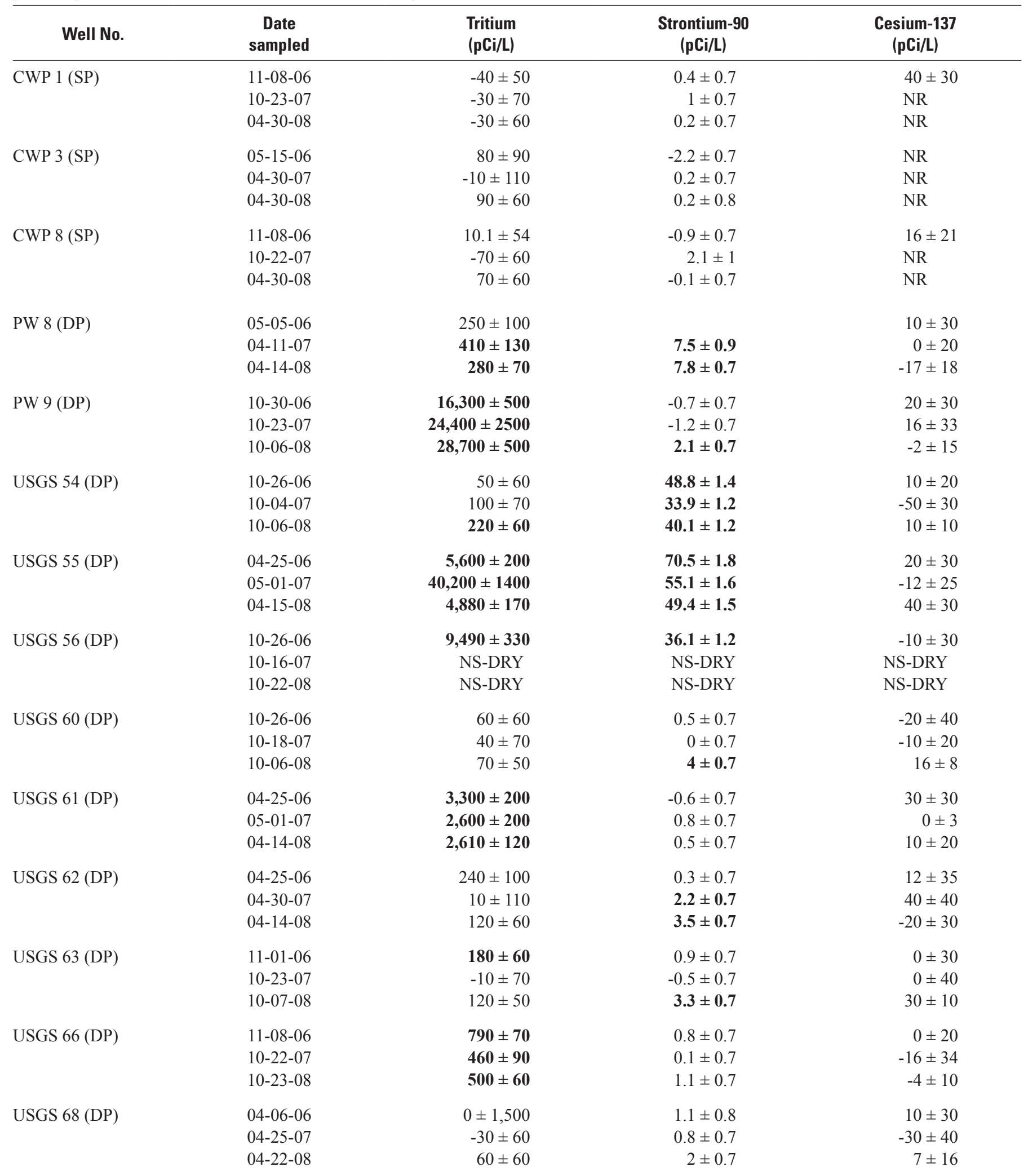


Table 7. Concentrations of tritium, strontium-90, and cesium-137 in perched groundwater from selected wells, Advanced Test Reactor Complex, Idaho National Laboratory, Idaho, 2006-08.-Continued

[Well No.: Locations of wells are shown in figure 7. Analyses completed by the Department of Energy's Radiological and Environmental Sciences Laboratory. Analytical uncertainties are reported as 1 times the sample standard deviation. Concentrations equal to or greater than 3 times the sample standard deviation are considered to be greater than the reporting level and are bold. Abbreviations: DP, well completed in deep perched groundwater; SP, well completed in shallow perched groundwater; NR, analysis not requested; NS-DRY, not sampled because the well was dry; NSEQ, not sampled because of equipment problems; pCi/L, picocurie per liter; USGS, U.S. Geological Survey. Symbol: \pm , plus or minus]

\begin{tabular}{|c|c|c|c|c|}
\hline Well No. & $\begin{array}{c}\text { Date } \\
\text { sampled }\end{array}$ & $\begin{array}{l}\text { Tritium } \\
\text { (pCi/L) }\end{array}$ & $\begin{array}{l}\text { Strontium-90 } \\
\text { (pCi/L) }\end{array}$ & $\begin{array}{c}\text { Cesium-137 } \\
\text { (pCi/L) }\end{array}$ \\
\hline USGS 69 (DP) & $\begin{array}{l}11-07-06 \\
10-23-07 \\
10-07-08\end{array}$ & $\begin{aligned}-60 & \pm 50 \\
-40 & \pm 60 \\
30 & \pm 50\end{aligned}$ & $\begin{array}{r}-0.1 \pm 0.7 \\
0.7 \pm 0.7 \\
1.7 \pm 0.7\end{array}$ & $\begin{aligned} 0 & \pm 40 \\
-80 & \pm 40 \\
15 & \pm 12\end{aligned}$ \\
\hline USGS 70 (DP) & $\begin{array}{l}05-16-06 \\
05-01-07 \\
4-14-2008\end{array}$ & $\begin{array}{r}2,800 \pm 200 \\
4,400 \pm 300 \\
2,900 \pm 130\end{array}$ & $\begin{array}{r}5 \pm 0.8 \\
42.1 \pm 1.2 \\
34.7 \pm 1.2\end{array}$ & $\begin{aligned}-30 & \pm 30 \\
30 & \pm 20 \\
-20 & \pm 20\end{aligned}$ \\
\hline USGS 71 (DP) & $\begin{array}{l}11-08-06 \\
10-22-07 \\
10-23-08\end{array}$ & $\begin{array}{c}\mathbf{1 , 1 3 0} \pm \mathbf{8 0} \\
\text { NSEQ } \\
\mathbf{1 , 0 3 0} \pm \mathbf{8 0}\end{array}$ & $\begin{array}{c}0.6 \pm 0.7 \\
\text { NSEQ } \\
0 \pm 0.6\end{array}$ & $\begin{array}{l}-40 \pm 20 \\
\text { NSEQ } \\
-16 \pm 8\end{array}$ \\
\hline USGS 72 (DP) & $\begin{array}{l}04-06-06 \\
04-25-07 \\
04-22-08\end{array}$ & $\begin{array}{r}80 \pm 90 \\
-60 \pm 110 \\
30 \pm 60\end{array}$ & $\begin{array}{l}0.3 \pm 0.7 \\
0.1 \pm 0.7 \\
1.8 \pm 0.7\end{array}$ & $\begin{aligned}-60 & \pm 30 \\
15 & \pm 19 \\
-10 & \pm 40\end{aligned}$ \\
\hline USGS 78 (DP) & $\begin{array}{l}11-08-06 \\
10-22-07 \\
10-23-08\end{array}$ & $\begin{array}{r}0 \pm 50 \\
0 \pm 70 \\
40 \pm 50\end{array}$ & $\begin{array}{r}-0.2 \pm 0.7 \\
-0.5 \pm 0.7 \\
\mathbf{2 . 6} \pm \mathbf{0 . 7}\end{array}$ & $\begin{array}{l}30 \pm 40 \\
14 \pm 23 \\
-5 \pm 11\end{array}$ \\
\hline
\end{tabular}

\section{Strontium-90}

Some wells completed in shallow perched groundwater at the ATRC were not sampled during 2006-08 because the wells were dry. The concentration of strontium-90 in well CWP 1, completed in shallow perched groundwater, varied between reportable and non-reportable concentrations during 2000-05 (Davis, 2008, table 10). Strontium-90 concentrations in water from wells CWP 1, 3, and 8 were less than the reporting level for all samples collected between 2006 and 2008 (table 7).

During at least one sampling event in the period 2006-08, concentrations of strontium-90 in water from wells PW 8, PW 9, USGS 54, 55, 56, 62, 63, 70, and 78, completed in deep perched groundwater at the ATRC, were greater than reporting levels (table 7, fig. 32). Concentrations ranged from $2.1 \pm 0.7 \mathrm{pCi} / \mathrm{L}$ in well $\mathrm{PW} 9$ to $70.5 \pm 1.8 \mathrm{pCi} / \mathrm{L}$ in well USGS 55. The distribution of strontium- 90 concentrations in perched groundwater from these wells during 2006-08 is attributed to exchange reactions between strontium-90 in solution and to sediments beneath the radioactive-waste infiltration ponds. Because data for strontium-90 disposal in 2006-08 were not available, fluctuations could not be correlated with disposal during this period. Strontium- 90 has not been detected in water from the Snake River Plain aquifer beneath the ATRC possibly because of the exclusive use of waste disposal ponds and lined evaporation ponds rather than injection of waste directly to the aquifer (Bartholomay and others, 1997, p. 30). The absence of detectable concentrations indicates that strontium-90 in solution is removed possibly by sorption and (or) exchange reactions in the unsaturated zone. Studies of strontium distribution coefficients for samples of surficial sediment, sedimentary interbeds, and sediment-filled fractures in basalts at the INL (Liszewski and others, 1997, 1998; Pace and others, 1999) support this theory.

\section{Gamma Spectrometry}

Water samples collected are routinely analyzed by gamma spectrometry and the results may yield concentrations of cesium-137, chromium-51, and cobalt-60. Water samples from wells completed in both shallow and deep perched groundwater at and near the ATRC have not yielded reportable concentrations of cesium-137 since 1997, chromium-51 since 1995, or cobalt-60 since 1998 (Davis, 2008, table 10; this report, table 7). 

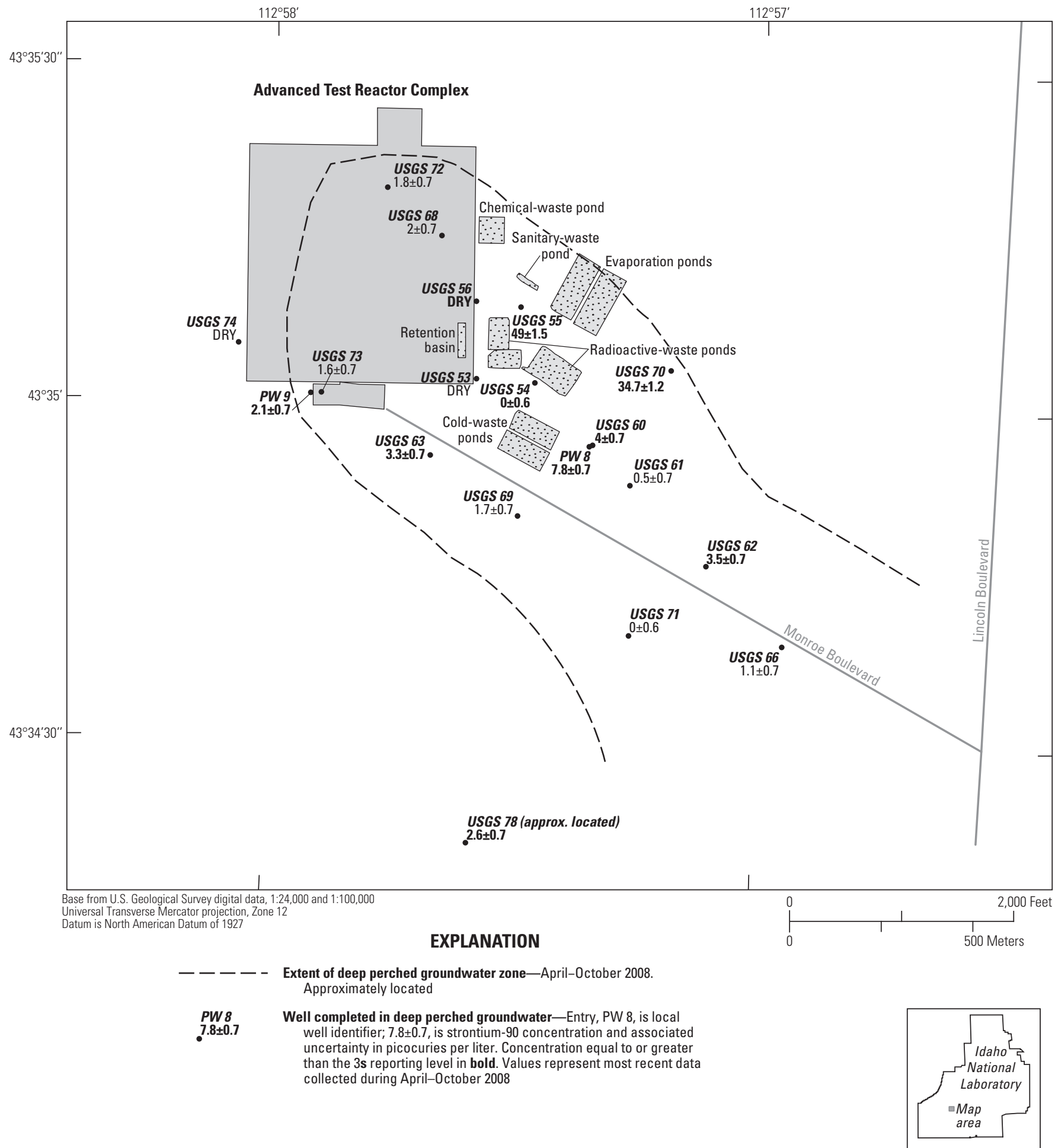

Figure 32. Concentrations of strontium-90 in water from wells completed in deep perched groundwater, Advanced Test Reactor Complex, Idaho National Laboratory, Idaho, April or October 2008. 


\section{Chromium}

Historically, dissolved chromium concentrations in shallow perched groundwater at the ATRC have been very low (less than or slightly greater than the LRL) because of lack of disposal of chromium in the cold waste ponds. Over the past decade, several wells were not sampled because they were dry and were removed from the USGS sampling program. During 2006-08, three shallow perched groundwater wells (CWP 1, 3, and 8) were sampled for chromium. Chromium was detected only in well CWP 1 in April 2008 with a concentration of $3 \mu \mathrm{g} / \mathrm{L}$ (table 8). The LRL for dissolved chromium varied from 1.2 to $2 \mu \mathrm{g} / \mathrm{L}$ during 2006-08. Estimated concentrations (table 8) less than the LRLs are treated as nondetected concentrations for consistency with treatment reported in previous publications and because an estimated concentration is considered a "qualitatively detected analyte" (Childress and others, 1999, p. 7).

Dissolved chromium was detected in water from 14 wells (PW 8-9, USGS 54-56, 60-63, 66, 68, 70, 71, and 73) completed in deep perched groundwater at the ATRC during 2006-08 (table 8). The highest concentrations during 2006-08 were in water from wells north and west of the radioactivewaste infiltration ponds (PW 9 and USGS 55, 56, 68, and 73). During 2006-08 the maximum concentration of chromium in deep perched groundwater at the ATRC was $125 \mu \mathrm{g} / \mathrm{L}$ in well USGS 56 in October 2006. During April-October 2008, detectable concentrations of dissolved chromium in wells completed in deep perched groundwater near the ATRC ranged from $4 \mu \mathrm{g} / \mathrm{L}$ in well USGS 60 to $34 \mu \mathrm{g} / \mathrm{L}$ in well USGS 73; however, well USGS 56 was not sampled during 2008 because the well was dry (table 8 and fig. 33).

Wastewater from ATRC cooling-tower operations contained an estimated 24,000 lb of chromium discharged to an infiltration pond during 1952-64 and an estimated 31,000 $\mathrm{lb}$ discharged to an injection well during 1965-72 (Mann and Knobel, 1988, p. 7). In October 1972, chromium used as a corrosion inhibitor in cooling-tower operations was replaced by a polyphosphate. No disposal of chromium to the subsurface at the ATRC was reported after 1972 (Bartholomay and Tucker, 2000). The presence of dissolved chromium in water from wells completed in perched groundwater indicates that water from these wells contains chromium discharged to the radioactive-waste infiltration ponds before 1965 when disposal practices changed to injection of cooling-tower blowdown water to the disposal well.

\section{Sodium}

During 2006-08, analyses were not made for dissolved sodium concentrations in shallow perched groundwater at the ATRC either because the wells were dry or because analyses for dissolved sodium were not requested from the laboratory (table 8). During April-October 2008, dissolved sodium concentrations in water from 17 wells completed in deep perched groundwater were determined. During April-October 2008, dissolved sodium concentrations ranged from 6 to $476 \mathrm{mg} / \mathrm{L}$. The highest concentration was in well USGS 68 (table 8); the sodium concentration in well USGS 68 increased from $370 \mathrm{mg} / \mathrm{L}$ in October 2005 (Davis, 2008 , table 11). Sodium concentrations in this well have varied through time and ranged from 476 to $504 \mathrm{mg} / \mathrm{L}$ during 2006-08. The reason for the variability of the concentrations in well USGS 68 probably is a result of movement of remnant water through the unsaturated zone from the chemical waste pond which was closed in 1999.

\section{Chloride}

Concentrations of chloride in most wells varied during 2006-08 (table 8). During April 2008, dissolved chloride concentrations in shallow perched groundwater ranged from $11 \mathrm{mg} / \mathrm{L}$ in well CWP 8 to $13 \mathrm{mg} / \mathrm{L}$ in wells CWP 1 and 3. Dissolved chloride concentrations in deep perched groundwater during April or October 2008 ranged from $4 \mathrm{mg} / \mathrm{L}$ in well USGS 78 to $43 \mathrm{mg} / \mathrm{L}$ in well USGS 73. Higher concentrations in wells may be a result of movement of remnant water through the unsaturated zone from the chemical waste pond which was closed in 1999.

\section{Sulfate}

The maximum dissolved sulfate concentration in shallow perched groundwater was $399 \mathrm{mg} / \mathrm{L}$ in well CWP 1 in November 2006. Concentrations of dissolved sulfate in this well vary greatly. During 2002-05, the concentrations ranged from 26 to $396 \mathrm{mg} / \mathrm{L}$ and during 2006-08 concentrations ranged from 66 to $399 \mathrm{mg} / \mathrm{L}$ (table 8). The variable concentrations are probably a result of changes in the amount of sulfate disposal to the cold-waste ponds. Concentrations of dissolved sulfate ranged from 94 to $242 \mathrm{mg} / \mathrm{L}$ during April-October 2008 in water from wells USGS 54, 60, 63,69 , and PW 8 that were completed in deep perched groundwater near the cold-waste ponds (table 8; fig. 7). These high concentrations indicate that water in the wells also was affected by discharge into the cold-waste ponds. During April-October 2008, the maximum concentration of dissolved sulfate in deep perched groundwater was $1477 \mathrm{mg} / \mathrm{L}$ in well USGS 68 (table 8), west of the chemical-waste pond (fig.7). The dissolved sulfate concentration in this well varied from 1240 to $1477 \mathrm{mg} / \mathrm{L}$ during 2006-08, an increase in concentrations from $951 \mathrm{mg} / \mathrm{L}$ in April 2005 (Davis, 2008, table 11). 
Table 8. Concentrations of selected dissolved ions in perched groundwater from selected wells, Advanced Test Reactor Complex, Idaho National Laboratory, Idaho, 2006-08.

[Well No.: Locations of wells are shown in figure 7. Analyses completed by the USGS National Water Quality Laboratory. Abbreviations: DP, well completed in deep perched groundwater; SP, well completed in shallow perched groundwater; NR, analysis not requested; NS-DRY, not sampled due to lack of water or because water level was below pump intake; NSEQ, not sampled because of equipment problems; E, estimated, and followed by the estimated value; $\mu \mathrm{g} / \mathrm{L}$, microgram per liter; mg/L, milligram per liter; USGS, U.S. Geological Survey. Symbol: <, less than respective reporting level]

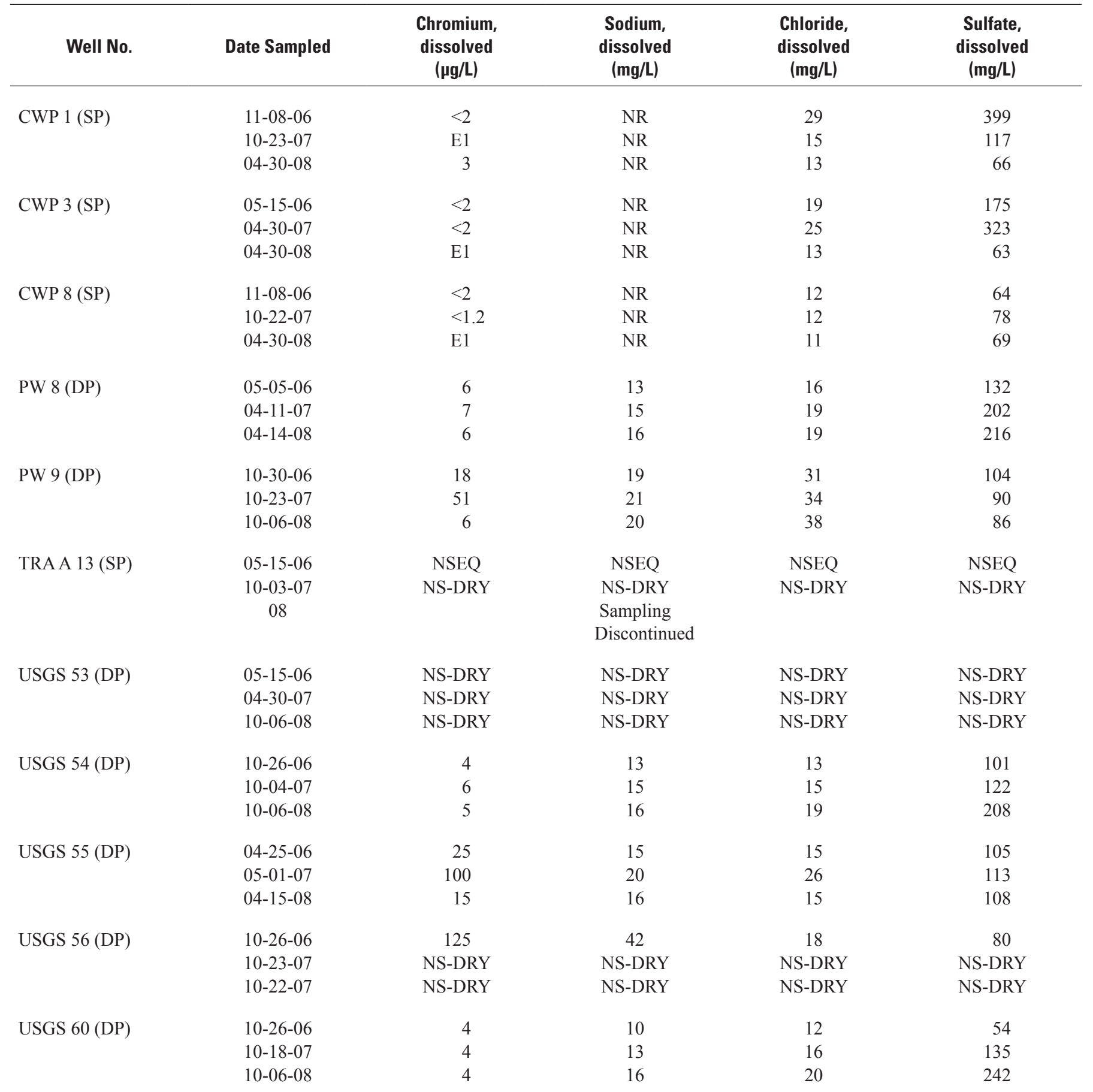


Table 8. Concentrations of selected dissolved ions in perched groundwater from selected wells, Advanced Test Reactor Complex, Idaho National Laboratory, Idaho, 2006-08.-Continued

[Well No.: Locations of wells are shown in figure 7. Analyses completed by the USGS National Water Quality Laboratory. Abbreviations: DP, well completed in deep perched groundwater; SP, well completed in shallow perched groundwater; NR, analysis not requested; NS-DRY, not sampled due to lack of water or because water level was below pump intake; NSEQ, not sampled because of equipment problems; E, estimated, and followed by the estimated value; $\mu \mathrm{g} / \mathrm{L}$, microgram per liter; mg/L, milligram per liter; USGS, U.S. Geological Survey. Symbol: <, less than respective reporting level]

\begin{tabular}{|c|c|c|c|c|c|}
\hline Well No. & Date Sampled & $\begin{array}{l}\text { Chromium, } \\
\text { dissolved } \\
(\mu \mathrm{g} / \mathrm{L})\end{array}$ & $\begin{array}{l}\text { Sodium, } \\
\text { dissolved } \\
\text { (mg/L) }\end{array}$ & $\begin{array}{l}\text { Chloride, } \\
\text { dissolved } \\
\text { (mg/L) }\end{array}$ & $\begin{array}{c}\text { Sulfate, } \\
\text { dissolved } \\
\text { (mg/L) }\end{array}$ \\
\hline \multirow[t]{3}{*}{ USGS 61 (DP) } & $04-25-06$ & 7 & 12 & 14 & 92 \\
\hline & 05-01-07 & 8 & 12 & 14 & 86 \\
\hline & 04-14-08 & 11 & 12 & 15 & 116 \\
\hline \multirow[t]{3}{*}{ USGS 62 (DP) } & $04-25-06$ & 9 & 15 & 20 & 212 \\
\hline & 04-30-07 & 8 & 16 & 19 & 199 \\
\hline & $04-14-08$ & 8 & 16 & 20 & 237 \\
\hline \multirow[t]{3}{*}{ USGS 63 (DP) } & $11-01-06$ & 22 & 14 & 16 & 127 \\
\hline & $10-23-07$ & 7 & 15 & 16 & 144 \\
\hline & $10-07-08$ & 11 & 17 & 21 & 241 \\
\hline \multirow[t]{3}{*}{ USGS 66 (DP) } & $11-08-06$ & E11 & 14 & 17 & 146 \\
\hline & $10-22-07$ & 7 & 16 & 17 & 158 \\
\hline & $10-23-08$ & 5 & 15 & 18 & 173 \\
\hline \multirow[t]{3}{*}{ USGS 68 (DP) } & 04-06-06 & 46 & 479 & 36 & 1240 \\
\hline & $04-25-07$ & 36 & 504 & 34 & 1471 \\
\hline & 04-22-08 & 44 & 476 & 36 & 1477 \\
\hline \multirow[t]{3}{*}{ USGS 69 (DP) } & $11-07-06$ & E2 & 9 & 12 & 62 \\
\hline & $10-23-07$ & E1 & 11 & 15 & 83 \\
\hline & $10-07-08$ & $<1.2$ & 11 & 15 & 94 \\
\hline \multirow[t]{3}{*}{ USGS 70 (DP) } & 05-16-06 & 12 & 14 & 16 & 134 \\
\hline & 05-01-07 & 23 & 16 & 17 & 155 \\
\hline & $04-14-08$ & 15 & 15 & 16 & 132 \\
\hline \multirow[t]{3}{*}{ USGS 71 (DP) } & $11-08-06$ & 14 & 12 & 18 & 164 \\
\hline & $10-22-07$ & NSEQ & NSEQ & NSEQ & NSEQ \\
\hline & $10-23-08$ & 6 & 12 & 18 & 166 \\
\hline \multirow[t]{3}{*}{ USGS 72 (DP) } & 04-06-06 & 1 & 32 & 17 & 28 \\
\hline & $04-25-07$ & 2 & 34 & 21 & 32 \\
\hline & 04-22-08 & 1 & 23 & 16 & 26 \\
\hline \multirow[t]{3}{*}{ USGS 73 (DP) } & $11-08-06$ & 32 & 18 & 38 & 73 \\
\hline & $05-05-08$ & 34 & 19 & 50 & 67 \\
\hline & $10-07-08$ & 32 & 14 & 43 & 66 \\
\hline \multirow{3}{*}{ USGS 78 (DP) } & $11-08-06$ & $<2$ & 6 & 5 & 20 \\
\hline & $10-22-07$ & $<1.2$ & 6 & 5 & 20 \\
\hline & $10-23-08$ & $<1.2$ & 6 & 4 & 21 \\
\hline
\end{tabular}



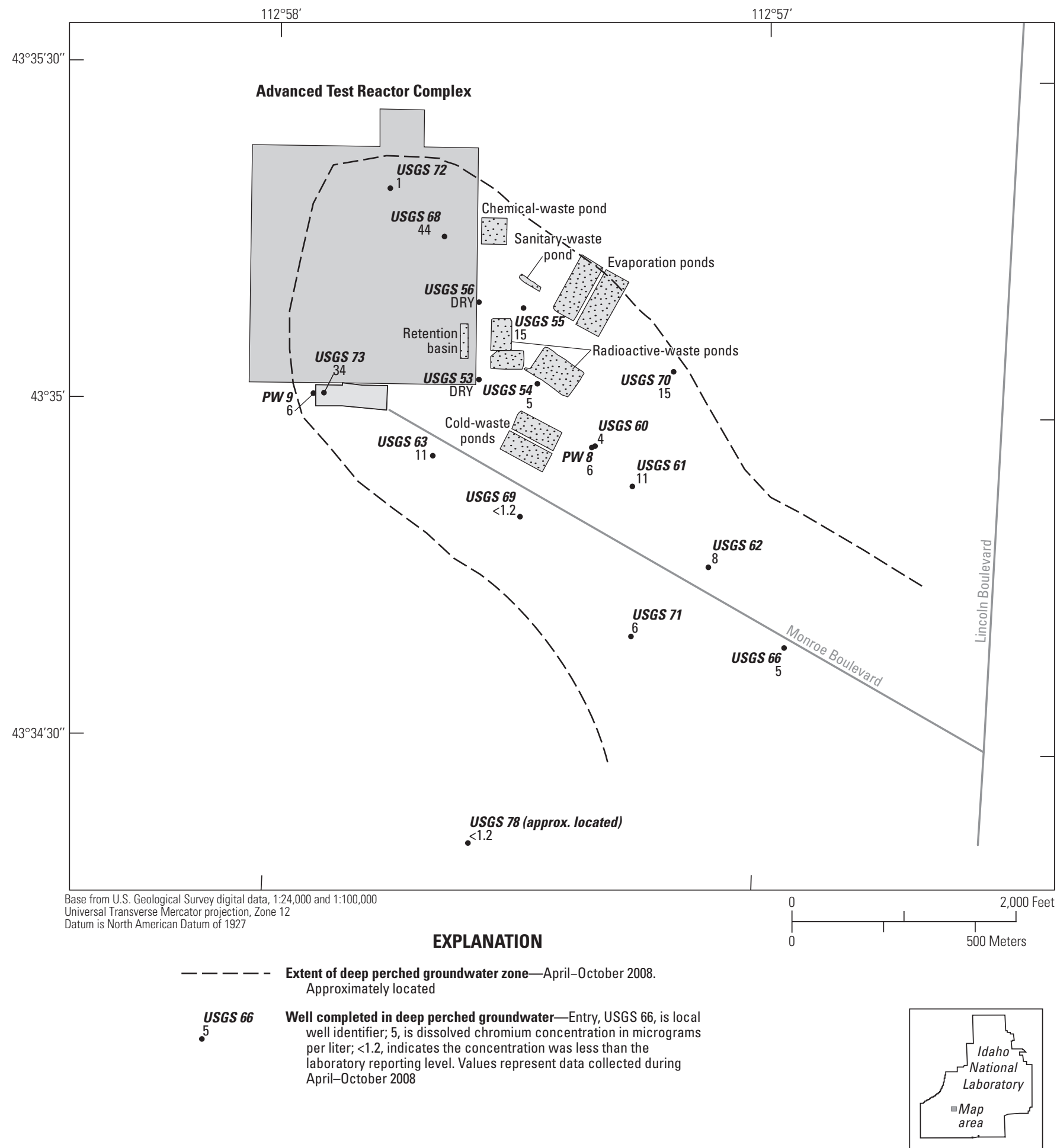

Figure 33. Concentrations of dissolved chromium in water from wells completed in deep perched groundwater, Advanced Test Reactor Complex, Idaho National Laboratory, Idaho, April or October 2008. 


\section{Idaho Nuclear Technology and Engineering Center}

Two percolation ponds were constructed south of the INTEC in 1984 and 1985 to replace the INTEC disposal well (fig. 7). Wastewater infiltrating from these ponds formed perched groundwater in the basalt and sedimentary interbeds above the eastern Snake River Plain aquifer. Perched groundwater has been found in other areas at the INTEC as well and may be attributed to leaking wastewater pipelines, leach fields, damaged casing in the upper part of the disposal well, other infiltration ponds, or landscape irrigation (Tucker and Orr, 1998).

Many auger holes were drilled in 1983 to obtain geohydrologic and engineering data at the site of the planned INTEC percolation ponds. Two holes, SWP 8 and 13 (Davis, 2008, fig. 21) subsequently were used as monitoring wells to sample and to measure water levels in shallow perched groundwater in surficial sediment at the ponds. Wells PW $1,2,3,4,5$, and 6 were completed in 1986 to monitor deep perched groundwater levels and water-quality changes under the INTEC percolation ponds (Davis, 2008, fig. 21). Well USGS 50 was used to monitor deep perched groundwater near the INTEC disposal well (fig. 7). Lack of available perched groundwater to sample and the history of nonreportable values of tritium in most of these wells resulted in the decision to remove wells SWP 8 and 13, and PW 2, 3, and 5 from the sampling schedule at various times during 2002-05 (Davis, 2008, fig. 21). During 2006-08, attempts were made to sample water from wells PW 1, 4, and 6, and USGS 50; however, wells PW 1 and PW 6 were dry. Only two water samples were collected from PW 4 in 2006 and 2007 and two water samples were collected from USGS 50 in 2007 and 2008. Davis (2008) gives a historical summary of water-sample analyses for wells completed in perched groundwater near the INTEC.

\section{Well PW 4}

A water sample collected from well PW 4 in November 2006 yielded a reportable concentration of tritium of $1,080 \pm 160 \mathrm{pCi} / \mathrm{L}$, which was lower than the concentration in 2005 of $1,400 \pm 160 \mathrm{pCi} / \mathrm{L}$. The water sample also contained a reportable concentration of strontium- 90 of $17.5 \pm 2.2 \mathrm{pCi} / \mathrm{L}$, which was higher than the concentration in 2005 of $11.4 \pm 1 \mathrm{pCi} / \mathrm{L}$. The cesium- 137 concentration was less than the reporting level. Concentrations of sodium, chloride, and sulfate were 98,155 , and $36 \mathrm{mg} / \mathrm{L}$, respectively. A water sample collected in October 2007 was analyzed only for sodium and the concentration was $95 \mathrm{mg} / \mathrm{L}$, similar to the concentration in 2006.

\section{Well USGS 50}

A water sample collected from well USGS 50 in October 2008 yielded a reportable concentration of tritium of $15,900 \pm 300 \mathrm{pCi} / \mathrm{L}$, lower than the concentration in November 2004 of $22,000 \pm 700 \mathrm{pCi} / \mathrm{L}$ and continued the decreasing trend of tritium concentrations in that well. The high concentrations of tritium in water from well USGS 50 may be a result of leakage of wastewater from ruptures in the upper part of the disposal well casing or to leakage from wastewater lines at the INTEC (Tucker and Orr, 1998). The decrease in tritium concentration may be attributed to radioactive decay or to the dilution of well water from a nonradioactive source such as landscape irrigation. The concentration of strontium-90 in water from well USGS 50 was $108 \pm 2 \mathrm{pCi} / \mathrm{L}$ in October 2008, a decrease from the concentration in November 2004 of $145 \pm 3 \mathrm{pCi} / \mathrm{L}$. Concentrations of strontium-90 have been decreasing since the $1980 \mathrm{~s}$ when concentrations were as high as $620 \pm 30 \mathrm{pCi} / \mathrm{L}$ in October 1982. Strontium-90 concentrations in water from well USGS 50 may be a result of the 1972 leak of $18,000 \mathrm{Ci}$ of strontium-90 in soils at the INTEC Tank Farm (fig. 7) (Cahn and others, 2006), leakage of wastewater from ruptures in the disposal well casing, or leakage from wastewater pipelines at the INTEC. Cesium-137 concentrations in the water sample from October 2008 were less than the reporting level. The absence of reportable concentrations of cesium-137 in perched groundwater at the INTEC is probably a result of decreased disposal and of sorption and (or) exchange of cesium-137 to minerals in sediments (Davis, 2008). Concentrations of sodium, chloride, and sulfate were 58, 52, and $39 \mathrm{mg} / \mathrm{L}$, respectively, in April 2007, and in October 2008, concentrations changed little at 57,52 , and $39 \mathrm{mg} / \mathrm{L}$, respectively. Concentrations of these constituents are similar to historical concentrations in water from this well. The nitrate (as N) concentration in the water sample from April 2007 was $22.5 \mathrm{mg} / \mathrm{L}$ and $18.9 \mathrm{mg} / \mathrm{L}$ in the water sample from October 2008. These concentrations represent a decrease from the concentration of $33.3 \mathrm{mg} / \mathrm{L}$ (as N) in November 2004, maintaining an overall decreasing trend since 1988. Sodium, chloride, sulfate, and nitrate (as N) concentrations may be a result of leakage of wastewater from pipelines at the INTEC.

\section{Radioactive Waste Management Complex}

Perched groundwater beneath the RWMC is in sedimentary interbeds in basalts and can be attributed primarily to local snowmelt and rain infiltration and to recharge from the Big Lost River and the INL spreading areas. This perched groundwater contains constituents leached 
from buried radioactive and organic-chemical wastes. Liquid and solid waste materials buried at the RWMC (ig. 1) also are sources of some constituents in perched groundwater. Perched groundwater beneath buried waste can be an integral part of the pathway for waste-constituent migration to the eastern Snake River Plain aquifer. The extent of this perched groundwater is affected by the waste-disposal practices.

Well USGS 92 (fig. 4) is in the SDA at the RWMC and is completed in a sedimentary interbed (Anderson and Lewis, 1989, p. 29) $214 \mathrm{ft}$ below land surface. Perched groundwater in this well has moved through overlying sediments and basalt and may contain waste constituents leached from radiochemical and organic chemical wastes buried in the SDA. Small amounts of water in well USGS 92 frequently preclude collection of an adequate water sample for all requested analyses. Adequate water samples for most requested analyses were collected during April or June 2006-08. During 2006-08, tritium concentrations in water samples from well USGS 92 (table 9) exceeded the reporting level ranging from $490 \pm 110 \mathrm{pCi} / \mathrm{L}$ in April 2006 to $300 \pm 80 \mathrm{pCi} / \mathrm{L}$ in June 2008. Tritium concentrations in water from well USGS 92 have varied through time.

Historically, the concentration of americium-241 was greater than the reporting level in October 1992 and the concentration of plutonium-238 was greater than the reporting level in November 1994 (Bartholomay, 1998). Since the 1990s, concentrations of these constituents have been less than the reporting levels.

Dissolved chloride concentrations in water from three water samples collected from well USGS 92 during 2006-08 were all $98 \mathrm{mg} / \mathrm{L}$ (table 9). This dissolved chloride concentration is slightly higher than the April 2002 concentration of $87 \mathrm{mg} / \mathrm{L}$, but consistent with concentrations measured historically.
In 1987, 9 VOCs were detected in water from well USGS 92 (Mann and Knobel, 1987, p. 16-17); in January 1990, 6 VOCs were detected (Tucker and Orr, 1998); and in April 1992, 18 VOCs were detected (Bartholomay, 1998, p. 28; Greene and Tucker, 1998). During 1996-98, 14 VOCs were detected (Bartholomay and Tucker, 2000). During 1999-2001, water from well USGS 92 was analyzed for the same VOCs as in previous years. During 2002-05, attempts were made each year to sample well USGS 92 that is completed in perched groundwater at the RWMC; however, lack of water in the well precluded obtaining an adequate water sample during most sampling events. Most of the same VOCs except chloroethane that were detected during 1999-2001 were detected during 2002-03; additionally, bromodichloromethane was detected.

Water from well USGS 92 was sampled for VOCs in April 2007. Table 10 lists the concentrations of nine VOCs detected. All of the VOCs detected in April 2007 had been detected in 2002-03. However, bromodichloromethane, 1,2-dichloroethane, benzene, methylene chloride (dichloromethane), 1,1,2-trichloroethane, cis-1,2-dichloroethene, and freon-113 (CFC-113) (1,1,2-trichloro-1,2,2-trifluoroethane), which were detected in 2002-03, were not detected in 2007. Additionally, all of the VOC concentrations detected in 2007 were significantly lower than those detected in 2002 or 2003, with the exception of toluene which was not detected in 2002-03 (table 10, this report; Davis, 2008, table 15). This decrease in VOC concentration may be a result of dilution by lateral infiltration of water flowing in the Big Lost River during water years 2005-06 (table 4) or removal of VOCs from the subsurface at the SDA by vapor vacuum extraction processes conducted by the INL contractor from 1996-present. The MRL for most VOCs was between 0.1 and $0.2 \mu \mathrm{g} / \mathrm{L}$ during 2006-08.

Table 9. Concentrations of tritium, strontium-90, cesium-137, selected transuranic elements, and dissolved chloride in perched groundwater from well USGS 92, Radioactive Waste Management Complex, Idaho National Laboratory, Idaho, 2006-08.

[Well No.: Location of well is shown in figure 7. Analyses completed by the Department of Energy's Radiological and Environmental Sciences Laboratory and the USGS National Water Quality Laboratory. Analyses for radionuclides, analytical uncertainties are reported as 1 times the sample standard deviation. Concentrations equal to or greater than 3 times the sample standard deviation are considered to be greater than the reporting level and are bold. Abbreviations: $\mathrm{pCi} / \mathrm{L}$, picocurie per liter; $\mathrm{mg} / \mathrm{L}$, milligram per liter. NR, analysis not requested or inadequate amount of sample; SL, sample lost at lab; USGS, U.S. Geological Survey. Symbol: \pm , plus or minus]

\begin{tabular}{lcrrrrrrr}
\hline Well No. & Date & $\begin{array}{c}\text { Tritium } \\
\text { (pCi/L) }\end{array}$ & $\begin{array}{c}\text { Strontium-90 } \\
\text { (pCi/L) }\end{array}$ & $\begin{array}{c}\text { Cesium-137 } \\
\text { (pCi/L) }\end{array}$ & $\begin{array}{c}\text { Plutonium-238 } \\
\text { (pCi/L) }\end{array}$ & $\begin{array}{c}\text { Plutonium-239, } \\
\mathbf{2 4 0} \text { (undivided) } \\
\text { (pCi/L) }\end{array}$ & $\begin{array}{c}\text { Americium-241 } \\
\text { (pCi/L) }\end{array}$ & $\begin{array}{c}\text { Chloride } \\
\text { (dissolved) } \\
\text { (mg/L) }\end{array}$ \\
\hline USGS 92 & $04-13-06$ & $\mathbf{4 9 0} \pm \mathbf{1 1 0}$ & $-0.13 \pm 0.76$ & $40 \pm 20$ & $\mathrm{SL}$ & $\mathrm{SL}$ & $\mathrm{SL}$ & 98 \\
& $04-23-07$ & $\mathbf{4 8 0} \pm \mathbf{1 3 0}$ & $0.9 \pm 0.7$ & $-10 \pm 20$ & $0.006 \pm 0.006$ & $-0.006 \pm 0.012$ & $0.03 \pm 0.02$ & 98 \\
& $06-12-08$ & $\mathbf{3 0 0} \pm \mathbf{8 0}$ & $1.5 \pm 0.7$ & $-20 \pm 20$ & $-0.003 \pm 0.007$ & $-0.006 \pm 0.004$ & $0.02 \pm 0.02$ & 98 \\
\hline
\end{tabular}


Table 10. Concentrations of selected volatile organic compounds in perched groundwater from well USGS 92, Radioactive Waste Management Complex, Idaho National Laboratory, Idaho, April 23, 2007.

[Location of well is shown in figure 7. Analyses completed by the U.S. Geological Survey's National Water Quality Laboratory using an analytical method that conforms to U.S. Environmental Protection Agency Method 524.2 (1995). Names in parentheses are alternate compound names. Abbreviations: NWIS, U.S. Geological Survey National Water Information System; $\mu \mathrm{g} / \mathrm{L}$, microgram per liter]

\begin{tabular}{|c|c|c|}
\hline Volatile organic compound name & $\begin{array}{c}\text { NWIS } \\
\text { parameter } \\
\text { code }\end{array}$ & $\begin{array}{c}\text { Concentration } \\
(\mu \mathrm{g} / \mathrm{L})\end{array}$ \\
\hline Chloroform (Trichloromethane) & 32106 & 72.3 \\
\hline Toluene & 34010 & 0.5 \\
\hline Tetrachloroethylene (Tetrachloroethene) & 34475 & 6 \\
\hline 1,1,1-trichloroethane & 34506 & 5.2 \\
\hline 1,2-dichloropropane & 34541 & 0.7 \\
\hline Trichloroethylene (Trichloroethene) & 39180 & 50.3 \\
\hline
\end{tabular}

\section{Summary}

Radiochemical and chemical wastewater discharged since 1952 to infiltration ponds and disposal wells, and waste buried in pits and trenches at the Idaho National Laboratory (INL) has affected water quality in the Snake River Plain aquifer and in perched groundwater zones at the INL. The U.S. Geological Survey (USGS), in cooperation with the U.S. Department of Energy, maintains aquifer and perched groundwater monitoring networks at the INL to determine hydrologic trends and to delineate the movement of radiochemical and chemical wastes in the eastern Snake River Plain aquifer and in perched groundwater zones.

Water in the Snake River Plain aquifer primarily moves through fractures and interflow zones in basalt, generally flows southwestward, and eventually discharges at springs along the Snake River. The aquifer is recharged primarily from infiltration of irrigation water, infiltration of streamflow, groundwater inflow from adjoining mountain drainage basins, and infiltration of precipitation.

During March-May 2008, the altitude of the water table in the Snake River Plain aquifer was about $4,560 \mathrm{ft}$ in the northern part of the INL, and about 4,410 to $4,420 \mathrm{ft}$ in the southwestern part. Water flowed southward and southwestward beneath the INL at an average hydraulic gradient of about $4 \mathrm{ft} / \mathrm{mi}$. Water levels in wells generally remained constant or declined in the INL area from March-May 2005 to March-May 2008. In the southwestern part of the INL, water levels were mostly unchanged from the March-May 2005 reporting period or rose slightly. In the central part of the INL, water levels declined about 1-3 ft and, in the northern part of the INL, water levels declined as much as $9 \mathrm{ft}$. Groundwater moves southwestward from the INL and eventually is discharged to springs along the Snake River near Twin Falls, Idaho, about 100 miles southwest of the INL. Estimated discharge from the springs was about 3.64 million acre-ft/yr for water year 2008.
Disposal of wastewater to infiltration ponds and infiltration of surface water at the Advanced Test Reactor Complex (ATRC) and Idaho Nuclear Technology and Engineering Center (INTEC) resulted in formation of perched groundwater in basalts and in sedimentary interbeds that overlie the Snake River Plain aquifer. Perched groundwater beneath the Radioactive Waste Management Complex (RWMC) formed from infiltration of snowmelt and rain and recharge from the Big Lost River and INL spreading areas. This perched groundwater contains constituents leached from buried radioactive and organic-chemical wastes. Perched groundwater is an integral part of the pathway for waste-constituent migration to the aquifer.

During 2005-07, six wells were equipped with multilevel Westbay ${ }^{\mathrm{TM}}$ packer sampling systems that allow water samples and pressure and temperature measurements to be acquired at isolated depths in each of the wells. This multilevel monitoring helps to describe the vertical distribution of water chemistry and pressure and temperature gradients in addition to the horizontal distribution information previously gathered from open boreholes. Beginning in 2005, the USGS and the INL contractor collaborated to instrument two wells with multi-level Westbay ${ }^{\mathrm{TM}}$ packer sampling systems. The USGS expanded the program in 2006 and 2007 to include four additional wells that were equipped with the systems. The vertical distribution of radiochemical and chemical constituents is variable at depth.

A tritium plume developed in the Snake River Plain aquifer from discharge of wastewater at the INL since the 1950s. In April or October 2008, reportable concentrations of tritium in water from aquifer wells ranged from $810 \pm 70$ to $8,570 \pm 190 \mathrm{pCi} / \mathrm{L}$ and the tritium plume extended southsouthwestward in the general direction of groundwater flow. In April or October 2008, concentrations of tritium in water samples generally decreased from the 2001-05 reporting period and all concentrations were less than the maximum contaminant level of $20,000 \mathrm{pCi} / \mathrm{L}$. 
At the ATRC, three wells completed in shallow perched groundwater were sampled for tritium during 2006-08; all concentrations were less than the reporting level. Tritium concentrations in water from 11 wells completed in deep perched groundwater (PW 8, PW 9, USGS 54, 55, 56, 61, 63, $66,70,71$, and 73 ) generally were greater than the reporting level during at least one sampling event during 2006-08. Tritium concentrations in water from 6 wells (USGS 60, 62, $68,69,72$, and 78 ) were less than the reporting level during 2006-08.

At the INTEC, a water sample collected from well PW 4 in November 2006 yielded a reportable concentration of tritium of $1,080 \pm 160 \mathrm{pCi} / \mathrm{L}$, which was lower than the concentration in 2005 of $1,400 \pm 160 \mathrm{pCi} / \mathrm{L}$. A water sample collected from well USGS 50 in October 2008 yielded a reportable concentration of tritium of $15,900 \pm 300$ $\mathrm{pCi} / \mathrm{L}$, lower than the concentration in November 2004 of $22,000 \pm 700 \mathrm{pCi} / \mathrm{L}$ and continued the decreasing trend of tritium concentrations in that well.

During April or October 2008, water from 52 aquifer wells was sampled for strontium-90 throughout the INL. Concentrations of strontium-90 in water from 24 wells exceeded the reporting level. Six Westbay ${ }^{\mathrm{TM}}$ equipped wells were sampled in August and September 2008 and did not contain reportable concentrations of strontium- 90 . Reportable concentrations of strontium-90 in the aquifer wells ranged from $2.2 \pm 0.7 \mathrm{pCi} / \mathrm{L}$ in water from well Site 9 to $32.7 \pm 1.2 \mathrm{pCi} / \mathrm{L}$ in water from well USGS 47 . The area of the strontium-90 plume near the INTEC extended south-southwestward in the general direction of groundwater flow. The concentrations in water from wells near and southwest of INTEC (USGS 36, 37, 38, 45, 47, 57, and 113), have varied since 1980; however, all wells have shown an overall decrease in strontium- 90 concentration.

Strontium-90 has not been detected within the eastern Snake River Plain aquifer beneath the ATRC partly because of the exclusive use of waste-disposal ponds and lined evaporation ponds rather than use of the disposal well for radioactive-wastewater disposal at ATRC. Sorption processes in sediments in the unsaturated zone beneath the radioactive waste-disposal pond could have minimized or prevented strontium-90 migration to the aquifer at the ATRC. Additionally, the stratigraphy beneath the ATRC is different from that beneath the INTEC; more sediment is present below the ATRC than the INTEC.

During 2006-08, attempts were made to sample water from wells PW 1, 4, and 6, and USGS 50 near the INTEC; however, wells PW 1 and PW 6 were dry. Only two water samples were collected from PW 4 in 2006 and 2007, and two water samples were collected from USGS 50 in 2007 and 2008. During 2006-07, water from well PW 4 contained a reportable concentration of strontium- 90 of $17.5 \pm 2.2 \mathrm{pCi} / \mathrm{L}$ in November 2006, which was higher than the concentration in 2005 of $11.4 \pm 1 \mathrm{pCi} / \mathrm{L}$. The concentration of strontium-90 in water from well USGS 50 was $108 \pm 2 \mathrm{pCi} / \mathrm{L}$ in October 2008, a decrease from the concentration in November 2004 of
$145 \pm 3 \mathrm{pCi} / \mathrm{L}$. Concentrations of strontium- 90 have been decreasing since the 1980s when concentrations were as high as $620 \pm 30 \mathrm{pCi} / \mathrm{L}$ in October 1982. Strontium-90 concentrations in water from well USGS 50 may be a result of the 1972 leak of $18,000 \mathrm{Ci}$ of strontium-90 in soils at the INTEC Tank Farm, leakage of wastewater from ruptures in the disposal well casing, or leakage from wastewater pipelines at the INTEC.

During 2006-08, concentrations of cesium-137, plutonium-238, and plutonium-239, -240 (undivided), and americium-241 were less than the reporting level in water from all wells sampled by the USGS at the INL, including all zones sampled in wells equipped with Westbay ${ }^{\mathrm{TM}}$ systems.

Gross alpha- and beta-particle radioactivity is a measure of the total radioactivity given off as alpha and beta particles during the radioactive decay process. The radioactivity is usually reported as if it occurred as one radionuclide. Gross alpha and beta measurements are used to screen for radioactivity in the aquifer as a possible indicator of groundwater contamination. Water samples collected during 2006-08 were analyzed for gross alpha- and gross beta-particle radioactivity by Radiological and Environmental Sciences Laboratory (RESL). In 2008, RESL increased the sensitivity of the gross alpha- and gross beta-particle radioactivity and changed the radionuclide reported for gross alpha from plutonium-239 to thorium-230, and for gross beta from cesium-137 to strontium-90/yttrium-90. The minimum detectable activity decreased from about 1.6 to $1.5 \mathrm{pCi} / \mathrm{L}$ for gross alpha and from about 6.4 to $3.4 \mathrm{pCi} / \mathrm{L}$ for gross beta, allowing for increased detectable concentrations for 2008 data.

During 2006-08, water samples from several aquifer wells were analyzed for chromium. In 2008, concentration of chromium in water from one aquifer well, USGS 65, south of ATRC, was $93 \mu \mathrm{g} / \mathrm{L}$, just less than the MCL, and concentrations steadily decreased during 2006-08. Concentrations in water samples from other wells ranged from 1.2 to $28.3 \mu \mathrm{g} / \mathrm{L}$.

Historically, dissolved chromium concentrations in shallow perched groundwater at the ATRC have been very low (less than or slightly greater than the laboratory reporting level [LRL]) as a result of lack of recent disposal of chromium in the cold waste ponds. Over the past decade, several wells were not sampled because they were dry and were removed from the USGS sampling program. During 2006-08, chromium was detected only in well CWP 1 in April 2008 with a concentration of $3 \mu \mathrm{g} / \mathrm{L}$. Dissolved chromium was detected in water from 14 wells (PW 8, 9, USGS 54-56, 60-63, 66, 68, 70, 71, and 73) completed in deep perched groundwater at the ATRC during 2006-08. During 2006-08, the maximum concentration of chromium in deep perched groundwater at the ATRC was $125 \mu \mathrm{g} / \mathrm{L}$ in well USGS 56 in October 2006. During April-October 2008, detectable concentrations of dissolved chromium in wells completed in deep perched groundwater near the ATRC ranged from $4 \mu \mathrm{g} / \mathrm{L}$ in well USGS 60 to $34 \mu \mathrm{g} / \mathrm{L}$ in well USGS 73; however, well USGS 56 was not sampled during 2008 because the well was dry. 
During 2006-08, the highest sodium concentration in water samples from aquifer wells near the INTEC was $40 \mathrm{mg} / \mathrm{L}$ in a water sample from well USGS 77. Concentrations of sodium in water from other wells south of the INTEC during 2006-08 generally were less than or equal to sodium concentrations detected in October 2005 with the exception of well USGS 47 which was slightly higher in 2008.

During 2006-08, analyses were not made for dissolved sodium concentrations in shallow perched groundwater at the ATRC. During April-October 2008, dissolved sodium concentrations in water from 17 wells completed in deep perched groundwater were determined. During April-October 2008, dissolved sodium concentrations ranged from 6 to $476 \mathrm{mg} / \mathrm{L}$.

The background chloride concentration in water from the Snake River Plain aquifer at the INL generally is about $15 \mathrm{mg} / \mathrm{L}$; the ambient chloride concentration near the INTEC is about $10 \mathrm{mg} / \mathrm{L}$; and, near the Central Facilities Area (CFA), the ambient chloride concentration is about $20 \mathrm{mg} / \mathrm{L}$. In 2008, concentrations of chloride in most water samples from wells closest to the INTEC and the CFA exceeded $20 \mathrm{mg} / \mathrm{L}$.

During April 2008, dissolved chloride concentrations in shallow perched groundwater ranged from $11 \mathrm{mg} / \mathrm{L}$ in well CWP 8 to $13 \mathrm{mg} / \mathrm{L}$ in wells CWP 1 and 3. Dissolved chloride concentrations in deep perched groundwater during April or October 2008 ranged from $4 \mathrm{mg} / \mathrm{L}$ in well USGS 78 to $43 \mathrm{mg} / \mathrm{L}$ in well USGS 73. Higher concentrations in wells may be a result of movement of remnant water through the unsaturated zone from the chemical waste pond which was closed in 1999.

In 2008, sulfate concentrations in water samples from nine wells in the south-central part of the INL exceeded the $40-\mathrm{mg} / \mathrm{L}$ background concentration of sulfate ranging from 40 to $157 \mathrm{mg} / \mathrm{L}$.

In April or October 2008, sulfate concentrations in water samples from USGS 88 and USGS 119, near the RWMC, were 50 and $39 \mathrm{mg} / \mathrm{L}$, respectively, similar to concentrations in October 2005. The sulfate concentrations that are greater than background concentration in water from these wells could have resulted from the well construction and (or) waste disposal at the RWMC.

The maximum dissolved sulfate concentration in shallow perched groundwater near the ATRC was $399 \mathrm{mg} / \mathrm{L}$ in well CWP 1 in November 2006. Concentrations of dissolved sulfate ranged from 94 to $242 \mathrm{mg} / \mathrm{L}$ during April-October 2008 in water from wells USGS 54, 60, 63, 69, and PW 8 that are completed in deep perched groundwater near the cold-waste ponds. These high concentrations indicate that water in the wells also was affected by discharge into the cold-waste ponds. During April-October 2008, the maximum concentration of dissolved sulfate in deep perched groundwater was $1,477 \mathrm{mg} / \mathrm{L}$ in well USGS 68, west of the chemical-waste pond. The dissolved sulfate concentration in this well varied from 1,240 to $1477 \mathrm{mg} / \mathrm{L}$ during 2006-08, an increase in concentrations from $951 \mathrm{mg} / \mathrm{L}$ in April 2005.
Concentrations of nitrate (as N) in groundwater not affected by wastewater disposal from INL facilities generally are less than the regional background of $1 \mathrm{mg} / \mathrm{L}$. In October 2008, concentrations of nitrate (as N) in water from most wells at and near the INTEC (wells USGS 40, 41, 47, 48, $51,52,67,77,111,113,114,116)$ exceeded the background concentration. Concentrations ranged from $2.2 \mathrm{mg} / \mathrm{L}$ (as N) in well USGS 113 to $5.97 \mathrm{mg} / \mathrm{L}$ (as N) in well USGS 47.

Historically, nitrate (as N) concentrations in water from aquifer wells near the RWMC slightly exceeded the regional background concentration of about $1 \mathrm{mg} / \mathrm{L}$. Since 1998, the concentrations of nitrate (as N) in water from wells USGS 88, 89 , and 119 have remained relatively unchanged, with 2008 concentrations of $0.9,1.7$, and $1.4 \mathrm{mg} / \mathrm{L}$, respectively.

In 2005, near the ATRC, the concentration of nitrate (as $\mathrm{N}$ ) in water from well USGS 65 was $1.6 \mathrm{mg} / \mathrm{L}$, and remained constant in 2008 with a concentration of $1.5 \mathrm{mg} / \mathrm{L}$. All concentrations measured in 2008 were less than the MCL for drinking water of $10 \mathrm{mg} / \mathrm{L}$ (as N).

During April or October 2008, water samples from four wells (CPP 1, USGS 34, 38, and 77, were analyzed for fluoride; detected concentrations ranged from 0.2 to $0.3 \mathrm{mg} / \mathrm{L}$. These concentrations are similar to the background concentrations which indicates that wastewater disposal has not had an appreciable effect on fluoride concentrations in the Snake River Plain aquifer near the INTEC.

Detectable concentrations of nonradioactive trace elements in water from the Snake River Plain aquifer at the INL varied during 2006-08.

During 2006-08, water samples from 30 wells were collected and analyzed for VOCs. Twelve VOCs were detected. Concentrations of from 1 to $10 \mathrm{VOCs}$ were detected in water samples from 11 wells. The primary VOCs detected included carbon tetrachloride; 1,1-dichloroethane; 1,1,1-trichloroethane; trichloroethylene; and tetrachloroethylene. Most VOCs fluctuated through time and show no distinct trend.

Water from well USGS 92 near the RWMC was sampled for VOCs in April 2007. Nine VOCs were detected. All of the VOCs detected in April 2007 had been detected in 2002-03. However, bromodichloromethane; 1,2-dichloroethane; benzene; methylene chloride (dichloromethane); 1,1,2-trichloroethane; cis-1,2-dichloroethene; and freon-113 (CFC-113) (1,1,2-trichloro-1,2,2-trifluoroethane), which were detected in 2002-03, were not detected in 2007. Additionally, all of the VOC concentrations detected in 2007 were significantly lower than those detected in 2002 or 2003 with the exception of toluene which was not detected in 2002-03. This may be a result of dilution by lateral infiltration of water flowing in the Big Lost River during water years 2005-06 or removal of VOCs from the subsurface at the Subsurface Disposal Area (SDA) by vapor vacuum extraction processes conducted by the INL contractor. 


\section{Acknowledgments}

The Department of Energy Radiological and Environmental Sciences Laboratory (RESL) at the Idaho National Laboratory provided radiochemical analyses of water samples. R. Douglas Carlson, Director, supervised technical staff at the RESL during 2006-08. The author is also grateful to Betty J. Tucker and Flint Raben, Hydrologic Technicians, U.S. Geological Survey, for data verification review.

\section{References Cited}

Ackerman, D.J., 1991, Transmissivity of the Snake River Plain aquifer at the Idaho National Engineering Laboratory, Idaho: U.S. Geological Survey Water-Resources Investigations Report 91-4058 (DOE/ID-22097), 35 p.

Ackerman, D. J., Rattray, G.W., Rousseau, J.P., Davis, L.C., and Orr, B. R., 2006, A conceptual model of ground-water flow in the eastern Snake River Plain aquifer at the Idaho National Laboratory and vicinity with implications for contaminant transport: U.S. Geological Survey Scientific Investigations Report 2006-5122 (DOE/ID-22198), 62 p.

Anderson, S.R., 1991, Stratigraphy of the unsaturated zone and uppermost part of the Snake River Plain aquifer at the Idaho Chemical Processing Plant and Test Reactors Area, Idaho National Engineering Laboratory, Idaho: U.S. Geological Survey Water-Resources Investigations Report 91-4010 (DOE/ID-22095), 71 p.

Anderson, S.R., Ackerman, D.J., Liszewski, M.J., and Freiburger, R.M., 1996, Stratigraphic data for wells at and near the Idaho National Engineering Laboratory, Idaho: U.S. Geological Survey Open-File Report 96-248 (DOE/ ID-22127), 27 p., 1 diskette.

Anderson, S.R., Kuntz, M.A., and Davis, L.C., 1999, Geologic controls of hydraulic conductivity in the Snake River Plain aquifer at and near the Idaho National Engineering and Environmental Laboratory, Idaho: U.S. Geological Survey Water-Resources Investigations Report 99-4033 (DOE/ ID-22155), $38 \mathrm{p}$.

Anderson, S.R. and Lewis, B.D., 1989, Stratigraphy of the unsaturated zone at the Radioactive Waste Management Complex, Idaho National Engineering Laboratory, Idaho: U.S. Geological Survey Water-Resources Investigations Report 89-4065 (DOE/ID-22080), 54 p.

Barraclough, J.T., and Jensen, R.G., 1976, Hydrologic data for the Idaho National Engineering Laboratory site, Idaho, 1971 to 1973: U.S. Geological Survey Open-File Report 75-318 (IDO-22055), $52 \mathrm{p}$.
Barraclough, J.T., Lewis, B.D., and Jensen, R.G., 1981, Hydrologic conditions at the Idaho National Engineering Laboratory, Idaho, emphasis: 1974-1978: U.S. Geological Survey Water-Resources Investigations Open-File Report 81-526 (IDO-22060), 116 p.

Barraclough, J.T., Robertson, J.B., and Janzer, V.J., 1976, Hydrology of the solid waste burial ground, as related to the potential migration of radionuclides, Idaho National Engineering Laboratory, with a section on drilling and sample analyses, by L.G. Saindon: U.S. Geological Survey Open-File Report 76-471 (IDO-22056), 183 p.

Barraclough, J.T., Teasdale, W.E., and Jensen, R.G., 1967a, Hydrology of the National Reactor Testing Station, Idaho, 1965: U.S. Geological Survey Open-File Report (IDO22048), $107 \mathrm{p}$.

Barraclough, J.T., Teasdale, W.E., Robertson, J.B., and Jensen, R.G., 1967b, Hydrology of the National Reactor Testing Station, Idaho, 1966: U.S. Geological Survey Open-File Report 67-12 (IDO-22049), 95 p.

Bartholomay, R.C., 1993, Concentrations of tritium and strontium-90 in water from selected wells at the Idaho National Engineering Laboratory after purging one, two, and three borehole volumes: U.S. Geological Survey WaterResources Investigations Report 93-4201 (DOE/ID-22111), $21 \mathrm{p}$.

Bartholomay, R.C., 1998, Distribution of selected radiochemical and chemical constituents in water from perched ground-water zones, Idaho National Engineering Laboratory, Idaho, 1992-95: U.S. Geological Survey WaterResources Investigations Report 98-4026 (DOE/ID-22145), $59 \mathrm{p}$.

Bartholomay, R.C., 2009, Iodine-129 in the Snake River Plain aquifer at and near the Idaho National Laboratory, Idaho, 2003 and 2007: U.S. Geological Survey Scientific Investigations Report 2009-5088, 28 p.

Bartholomay, R.C., Hill, G.H., and Randolph, R.B., 1999, Statistical comparison of gross alpha- and gross betaparticle activity in water analyzed using two different laboratory methods, in 41st Rocky Mountain Conference on Analytical Chemistry, 41st, Denver, Colo., 1999, Final program and abstracts, p. 132.

Bartholomay, R.C., Knobel, L.L., and Rousseau, J.P., 2003, Field methods and quality assurance plan for quality-ofwater activities, U.S. Geological Survey, Idaho National Engineering and Engineering Laboratory, Idaho: U.S. Geological Survey Open-File Report 2003-42 (DOE/ ID-22182), $45 \mathrm{p}$. 
Bartholomay, R.C., Knobel, L.L., Tucker, B.J., and Twining B.V., 2001a, Chemical and radiochemical constituents in water from wells in the vicinity of the Naval Reactors Facility, Idaho National Engineering and Environmental Laboratory, Idaho, 2000: U.S. Geological Survey Open-File Report 2002-148 (DOE/ID-22178), 34 p.

Bartholomay, R.C., Knobel, L.L., Tucker, B.J., and Twining B.V., 2001b, Chemical and radiochemical constituents in water from wells in the vicinity of the Naval Reactors Facility, Idaho National Engineering and Environmental Laboratory, Idaho, 1999: U.S. Geological Survey Open-File Report 2001-27 (DOE/ID-22172), 37 p.

Bartholomay, R.C., Orr, B.R., Liszewski, M.J., and Jensen, R.G., 1995, Hydrologic conditions and distribution of selected radiochemical and chemical constituents in water, Snake River Plain aquifer, Idaho National Engineering Laboratory, Idaho, 1989 through 1991: U.S. Geological Survey Water-Resources Investigations Report 95-4175 (DOE/ID-22123), $47 \mathrm{p}$.

Bartholomay, R.C., and Tucker, B.J., 2000, Distribution of selected radiochemical and chemical constituents in perched ground water, Idaho National Engineering and Environmental Laboratory, Idaho, 1996-98: U.S. Geological Survey Water-Resources Investigations Report 00-4222 (DOE/ID-22168), 51 p.

Bartholomay, R.C., Tucker, B.J., Ackerman, D.J., and Liszewski, M.J., 1997, Hydrologic conditions and distribution of selected radiochemical and chemical constituents in water, Snake River Plain aquifer, Idaho National Engineering Laboratory, Idaho, 1992 through 1995: U.S. Geological Survey Water-Resources Investigations Report 97-4086 (DOE/ID-22137), 57 p.

Bartholomay, R.C., Tucker, B.J., Davis, L.C., and Green, M.R., 2000, Hydrologic conditions and distribution of selected constituents in water, Snake River Plain aquifer, Idaho National Engineering and Environmental Laboratory, Idaho, 1996 through 1998: U.S. Geological Survey WaterResources Investigations Report 00-4192 (DOE/ID-22167), $52 \mathrm{p}$.

Bartholomay, R.C., and Twining, B.V., 2010, Chemical constituents in groundwater from multiple zones in the eastern Snake River Plain aquifer at the Idaho National Laboratory, Idaho: U.S. Geological Survey Scientific Investigations Report 2010-5116 (DOE/ID 22211), 81 p.

Bartholomay, R.C., and Williams, L.M., 1996, Evaluation of preservation methods for selected nutrients in ground water at the Idaho National Engineering Laboratory, Idaho: U.S. Geological Survey Water-Resources Investigations Report 96-4260 (DOE/ID-22131), 16 p.
Bennett, C.M., 1990, Streamflow losses and ground-water level changes along the Big Lost River at the Idaho National Engineering Laboratory, Idaho: U.S. Geological Survey Water-Resources Investigations Report 90-4067 (DOE/ ID-22091), 49 p.

Bodnar, L.Z., and Percival, D.R., eds., 1982, Analytical Chemistry Branch procedures manual-Radiological and Environmental Sciences Laboratory: U.S. Department of Energy Report IDO-12096 [variously paged].

Cahn, L.S., Abbott, M.L., Keck, J.F., Martian, Peter, Schafer, A.L., and Swenson, M.C., 2006, Operable Unit 3-14 Tank Farm soil and groundwater remedial investigation/ baseline risk assessment: U.S. Department of Energy, Idaho Operations Office, DOE/NE-ID-11227 [variously paged].

Cassidy, G.B., 1984, Idaho National Engineering Laboratory industrial waste management information for 1983 and record-to-date: U.S. Department of Energy, Waste Management Programs Division, Idaho Operations Office Publication DOE/ID-10057 (83), 99 p.

Cecil, L.D., Knobel, L.L., Wegner, S.J., and Moore, L.L., 1989, Evaluation of field sampling and preservation methods for strontium-90 in ground water at the Idaho National Engineering Laboratory: U.S. Geological Survey Water-Resources Investigations Report 89-4146 (DOE/ ID-22083), $24 \mathrm{p}$.

Cecil, L.D., Orr, B.R., Norton, Teddy, and Anderson, S.R., 1991, Formation of perched ground-water zones and concentrations of selected chemical constituents in water, Idaho National Engineering Laboratory, Idaho, 1986-88: U.S. Geological Survey Water-Resources Investigations Report 91-4166 (DOE/ID-22100), 53 p.

Childress, C.J.O., Forman, W.T., Connor, B.F., and Maloney, T.J., 1999, New reporting procedures based on long-term method detection levels and some considerations for interpretations of water-quality data provided by the U.S. Geological Survey National Water Quality Laboratory: U.S. Geological Survey Open-File Report 99-193, 19 p.

Claassen, H.C., 1982, Guidelines and techniques for obtaining water samples that accurately represent the water chemistry of an aquifer: U.S. Geological Survey Open-File Report 82-1024, 49 p.

Currie, L.A., 1984, Lower limit of detection-definition and elaboration of a proposed position for radiological effluent and environmental measurements: U.S. Nuclear Regulatory Commission NUREG/CR-4007, 139 p.

Davis, L.C., 2006a, An update of the distribution of selected radiochemical and chemical constituents in perched ground water, Idaho National Laboratory, Idaho, emphasis 19992001: U.S. Geological Survey Scientific Investigations Report 2006-5236 (DOE/ID-22199), 48 p. 
Davis, L.C., 2006b, An update of hydrologic conditions and distribution of selected constituents in water, Snake River Plain aquifer, emphasis 1999-2001: U.S. Geological Survey Scientific Investigations Report 2006-5088 (DOE/ ID-22197), 48 p.

Davis, L.C., 2008, An update of hydrologic conditions and distribution of selected constituents in water, Snake River Plain aquifer and perched-water zones, emphasis 2002-05: U.S. Geological Survey Scientific Investigations Report 2008-5089 (DOE/ID-22203), 74 p.

Faires, L.M., 1993, Methods of analysis by the U.S. Geological Survey National Water Quality LaboratoryDeterminations of metals in water by inductively coupled plasma-mass spectrometry: U.S. Geological Survey OpenFile Report 92-634, 28 p.

Fishman, M.J., ed., 1993, Methods of analysis by the U.S. Geological Survey National Water Quality LaboratoryDetermination of inorganic and organic constituents in water and fluvial sediments: U.S. Geological Survey OpenFile Report 93-125, 217 p.

Fishman, M.J., and Friedman, L.C., eds., 1989, Methods for determination of inorganic substances in water and fluvial sediments: U.S. Geological Survey Techniques of WaterResources Investigations, book 5, chap. A1, 545 p.

French, D.L., Lisee, D.J., and Taylor, K.A., 1997, Idaho National Engineering and Environmental Laboratory nonradiological waste management information for 1996 and record-to-date: U.S. Department of Energy, Waste Management Programs Division, Idaho Operations Office Publication, DOE/ID-10057 (96) [variously paged].

French, D.L., Tallman, R.E., and Taylor, K.A., 1999a, Idaho National Engineering and Environmental Laboratory nonradiological waste management information for 1998 and record-to-date: U.S. Department of Energy, Waste Management Programs Division, Idaho Operations Office Publication, DOE/ID-10057 (98) [variously paged].

French, D.L., Tallman, R.E., and Taylor, K.A., 1999b, Radioactive waste management information for 1998 and record-to-date: U.S. Department of Energy, Waste Management Programs Division, Idaho Operations Office Publication, DOE/ID-10054 (98) [variously paged].

Goerlitz, D.F., and Brown, Eugene, 1972, Methods for analysis of organic substances in water: U.S. Geological Survey Techniques of Water-Resources Investigations, book 5, chap. A3, 40 p.

Greene, M.J., and Tucker, B.J., 1998, Purgeable organic compounds in water at or near the Idaho National Engineering Laboratory, Idaho, 1992-95: U.S. Geological Survey Open-File Report 98-51 (DOE/ID-22146), 21 p.
Hem, J.D., 1989, Study and interpretation of the chemical characteristics of natural water (3d ed.): U.S. Geological Survey Water-Supply Paper 2254, 263 p.

Holdren, K.J., Becker, B.H., Hampton, N.L., Koeppen, L.D., Magnuson, S.O., Meyer, T.J., Olson, G.L., and Sondrup, A.J., 2002, Ancillary basis for risk analysis of the Subsurface Disposal Area: Idaho National Engineering and Environmental Laboratory, U.S. Department of Energy, Idaho Operations Office, INEEL/EXT-02-01125 [variously paged].

Hull, L.C., 1989, Conceptual model and description of the affected environment for the TRA warm waste pond (Waste Management Unit TRA-03): EG\&G Idaho Informal Report EGG-ER-8644, 125 p.

Jones, P.H., 1961, Hydrology of waste disposal, National Reactor Testing Station, Idaho, an interim report: U.S. Atomic Energy Commission, Idaho Operations Office Publication IDO-22042-USGS, 152 p.

Kjelstrom, L.C., 1995, Methods to estimate annual mean spring discharge to the Snake River between Milner Dam and King Hill, Idaho: U.S. Geological Survey WaterResources Investigations Report 95-4055, 9 p.

Knobel, L.L., 2006, Evaluation of well-purging effects on water-quality results for samples collected from the eastern Snake River Plain aquifer underlying the Idaho National Laboratory, Idaho: U.S. Geological Survey Scientific Investigations Report 2006-5232 (DOE/ID-22200), 52 p.

Knobel, L.L., and Mann, L.J., 1993, Sampling for purgeable organic compounds using positive-displacement piston and centrifugal submersible pumps-A comparative study: Ground Water Monitoring Review, Spring 1993, p. 142-148.

Knobel, L.L., Orr, B.R., and Cecil, L.D., 1992, Summary of background concentrations of selected radiochemical and chemical constituents in groundwater from the Snake River Plain aquifer, Idaho-Estimated from an analysis of previously published data: Journal of the Idaho Academy of Science, v. 28, n. 1, p. 48-61.

Knobel, L.L., Tucker, B.J. and Rousseau, J.P., 2008, Field methods and quality-assurance plan for quality-ofwater activities, U.S. Geological Survey, Idaho National Laboratory, Idaho: U.S. Geological Survey Open-File Report 2008-1165 (DOE/ID-22206), 36 p.

Lewis, B.D., and Jensen, R.G., 1985, Hydrologic conditions at the Idaho National Engineering Laboratory, Idaho, 1979-1981 update: U.S. Geological Survey Hydrologic Investigations Atlas HA-674, 2 sheets. 
Liszewski, M.J., and Mann, L.J., 1992, Purgeable organic compounds in ground water at the Idaho National Engineering Laboratory, Idaho, 1990 and 1991: U.S. Geological Survey Open-File Report 92-174 (DOE/ ID-22104), $19 \mathrm{p}$.

Liszewski, M.J., Rosentreter, J.J., and Miller, K.E., 1997, Strontium distribution coefficients of surficial sediment samples from the Idaho National Engineering Laboratory, Idaho: U.S. Geological Survey Water-Resources Investigative Report 97-4044 (DOE/ID-22140), 33 p.

Liszewski, M.J., Rosentreter, J.J., Miller, K.E., and Bartholomay, R.C., 1998, Strontium distribution coefficients of surficial and sedimentary interbed samples from the Idaho National Engineering and Environmental Laboratory, Idaho: U.S. Geological Survey Water-Resources Investigative Report 98-4073 (DOE/ID-22149), 55 p.

Lucius, J.E., Olhoeft, G.R., Hill, P.L., and Duke, S.K., 1989, Properties and hazards of 108 selected substances: U.S. Geological Survey Open-File Report 89-491, 538 p.

Mann, L.J., 1986, Hydraulic properties of rock units and chemical quality of water for INEL-1-A 10,365-foot deep test hole drilled at the Idaho National Engineering Laboratory, Idaho: U.S. Geological Survey Water-Resources Investigations Report 86-4020 (DOE/ID-22070), 23 p.

Mann, L.J., 1990, Purgeable organic compounds in ground water at the Idaho National Engineering Laboratory, Idaho-1988 and 1989: U.S. Geological Survey Open-File Report 90-367 (DOE/ID-22089), 17 p.

Mann, L.J., 1996, Quality-assurance plan and field methods for quality-of-water activities, U.S. Geological Survey, Idaho National Engineering Laboratory, Idaho: U.S. Geological Survey Open-File Report 96-615 (DOE/ ID-22132), $37 \mathrm{p}$.

Mann, L.J., and Cecil, L.D., 1990, Tritium in ground water at the Idaho National Engineering Laboratory, Idaho: U.S. Geological Survey Water-Resources Investigations Report 90-4090 (DOE/ID-22090), 35 p.

Mann, L.J., and Knobel, L.L., 1987, Purgeable organic compounds in ground water at the Idaho National Engineering Laboratory, Idaho: U.S. Geological Survey Open-File Report 87-766 (DOE/ID-22074), 23 p.

Mann, L.J., and Knobel, L.L., 1988, Concentrations of nine trace metals in ground water at the Idaho National Engineering Laboratory, Idaho: U.S. Geological Survey Open-File Report 88-332 (DOE/ID-22075), 17 p.
Morris, D.A., Barraclough, J.T., Chase, G.H., Teasdale, W.E., and Jensen, R.G., 1965, Hydrology of subsurface waste disposal, National Reactor Testing Station, Idaho, annual progress report, 1964: U.S. Atomic Energy Commission, Idaho Operations Office Publication, IDO-22047-USGS, $186 \mathrm{p}$.

Morris, D.A., Barraclough, J.T., Hogenson, G.M., Shuter, Eugene, Teasdale, W.E., Ralston, D.A., and Jensen, R.G., 1964, Hydrology of subsurface waste disposal, National Reactor Testing Station, Idaho, annual progress report, 1963: U.S. Atomic Energy Commission, Idaho Operations Office Publication, IDO-22046-USGS, 97 p.

Morris, D.A., Hogenson, G.M., Shuter, Eugene, and Teasdale, W.E., 1963, Hydrology of waste disposal, National Reactor Testing Station, Idaho, annual progress report, 1962: U.S. Atomic Energy Commission, Idaho Operations Office Publication, IDO-22044-USGS, 99 p.

North Wind, Inc., 2006, Drilling, coring, and installation of two deep monitoring wells (Middle 2051 and Middle 2050A) in Fiscal Year 2005: Prepared under subcontract No. 00026016 for the U.S. Department of Energy, Rpt-178, Revision 0 , variously paged.

Orr, B.R., 1999, A transient numerical simulation of perched ground-water flow at the Test Reactor Area, Idaho National Engineering and Environmental Laboratory, Idaho, 195294: U.S. Geological Survey Water-Resources Investigations Report 99-4277 (DOE/ID-22162), 54 p.

Orr, B.R., and Cecil, L.D., 1991, Hydrologic conditions and distribution of selected chemical constituents in water, Snake River Plain aquifer, Idaho National Engineering Laboratory, Idaho, 1986 to 1988: U.S. Geological Survey Water-Resources Investigations Report 91-4047 (DOE/ ID-22096), $56 \mathrm{p}$.

Orr, B.R., Cecil, L.D., and Knobel, L.L., 1991, Background concentrations of selected radionuclides, organic compounds, and chemical constituents in ground water in the vicinity of the Idaho National Engineering Laboratory: U.S. Geological Survey Water-Resources Investigations Report 91-4015 (DOE/ID-22094), 52 p.

Pace, M.N., Rosentreter, J.J., and Bartholomay, R.C., 1999, Strontium distribution coefficients of basalt and sediment infill samples from the Idaho National Engineering and Environmental Laboratory, Idaho: U.S. Geological Survey Water-Resources Investigations Report 99-4145 (DOE/ ID-22158), $56 \mathrm{p}$.

Pittman, J.R., Jensen, R.G., and Fischer, P.R., 1988, Hydrologic conditions at the Idaho National Engineering Laboratory, 1982 to 1985: U.S. Geological Survey WaterResources Investigations Report 89-4008 (DOE/ID-22078), $73 \mathrm{p}$. 
Pritt, J. W., 1989, Quality assurance of sample containers and preservatives at the U.S. Geological Survey National Water Quality Laboratory, in Pederson, G.L., and Smith, M.M., compilers, U.S. Geological Survey Second National Symposium on Water Quality - abstracts of the technical sessions: U.S. Geological Survey Open-File Report 89-409, $111 \mathrm{p}$.

Robertson, J.B., Schoen, Robert, and Barraclough, J.T., 1974, The influence of liquid waste disposal on the geochemistry of water at the National Reactor Testing Station, Idaho, 1952-1970: U.S. Geological Survey Open-File Report 73-238 (IDO-22053), $231 \mathrm{p}$.

Sehlke, Gerald, and Bickford, F.E., 1993, Idaho National Engineering Laboratory ground-water monitoring plan: EG\&G Idaho, Inc., and Golder Associates, Inc., DOE/ ID-10441, v. 1-2 [variously paged].

Stevens, H.H., Jr., Ficke, J.F., and Smoot, G.F., 1975, Water temperature - Influential factors, field measurement, and data presentation: U.S. Geological Survey Techniques of Water-Resources Investigations, book 1, chap. D1, 65 p.

S.M. Stoller Corporation, 2002a, Idaho National Engineering and Environmental Laboratory site environmental report, calendar year 1999: U.S. Department of Energy, Idaho Operations Office, DOE/ID-12082 (99) [variously paged].

S.M. Stoller Corporation, 2002b, Idaho National Engineering and Environmental Laboratory site environmental report, calendar year 2000: U.S. Department of Energy, Idaho Operations Office, DOE/ID-12082 (00) [variously paged].

S.M. Stoller Corporation, 2002c, Idaho National Engineering and Environmental Laboratory site environmental report, calendar year 2001: U.S. Department of Energy, Idaho Operations Office, DOE/ID-12082 (01) [variously paged].

S.M. Stoller Corporation, 2003, Idaho National Engineering and Environmental Laboratory site environmental report, calendar year 2002: U.S. Department of Energy, Idaho Operations Office, DOE/ID-12082 (02) [variously paged].

S.M. Stoller Corporation, 2004, Idaho National Engineering and Environmental Laboratory site environmental report, calendar year 2003: U.S. Department of Energy, Idaho Operations Office, DOE/ID-12082 (03) [variously paged].

S.M. Stoller Corporation, 2009, Idaho National Laboratory site environmental report, calendar year 2008: U.S. Department of Energy, Idaho Operations Office, DOE/ ID-12082 (08) [variously paged].

Timme, P.J., 1995, National Water Quality Laboratory, 1995 services catalog: U.S. Geological Survey Open-File Report 95-352, $120 \mathrm{p}$.
Tucker, B.J., and Orr, B.R., 1998, Distribution of selected radiochemical and chemical constituents in perched ground water, Idaho National Engineering Laboratory, Idaho, 1989 91: U.S. Geological Survey Water-Resources Investigations Report 98-4028 (DOE/ID-22144), 62 p.

U.S. Department of Energy, Environmental Sciences Branch, Radiological and Environmental Sciences Laboratory, 1991, INEL site environmental surveillance data for the fourth quarter, 1990: U.S. Department of Energy Environmental Surveillance Quarterly Report, $49 \mathrm{p}$.

U.S. Environmental Protection Agency, 1998, Protection of environment - Code of Federal Regulations 40:

Washington, D.C., Office of the Federal Register, National Archives and Records Administration, Parts 136 to 149, $808 \mathrm{p}$.

U.S. Environmental Protection Agency, 2001, Protection of environment - Code of Federal Regulations 40:

Washington, D.C., Office of the Federal Register, National Archives and Records Administration, Parts 136 to 149, $833 \mathrm{p}$.

U.S. Geological Survey, 1985, National water summary, 1984-Hydrologic events, selected water-quality trends, and ground-water resources: U.S. Geological Survey WaterSupply Paper 2275, $467 \mathrm{p}$.

U.S. Geological Survey, 2006, 13127000 Big Lost River below Mackay Reservoir, near Mackay, ID-Upper Snake Basin, Big Lost Subbasin: U.S. Geological Survey WaterData Report, WDR-US-2006, accessed October 1, 2009, at http://wdr.water.usgs.gov/wy2006/pdfs/13127000.2006.pdf.

U.S. Geological Survey, 2007, 13127000 Big Lost River below Mackay Reservoir, near Mackay, ID - Upper Snake Basin, Big Lost Subbasin: U.S. Geological Survey WaterData Report, WDR-US-2007, accessed October 1, 2009, at http://wdr.water.usgs.gov/wy2007/pdfs/13127000.2007.pdf.

U.S. Geological Survey. 2008, 1312700 Big Lost River below Mackay Reservoir, near Mackay, ID-Upper Snake Basin, Big Lost Subbasin: U.S. Geological Survey Water-Data Report, WDR-US-2008, accessed October 1, 2009, at http:// wdr.water.usgs.gov/wy2008/pdfs/13127000.2008.pdf.

U.S. Geological Survey, 2010a, USGS Publications Warehouse: U.S. Geological Survey database, accessed July 7, 2010, at http://pubs.er.usgs.gov/.

U.S. Geological Survey, 2010b, National Water Information System-Web interface, USGS water data for Idaho: U.S. Geological Survey database, accessed in 2005 at http:// waterdata.usgs.gov/id/nwis/nwis. 
U.S. Geological Survey 2010c, National Water Information System-Web interface, USGS water-quality data for Idaho: U.S. Geological Survey database, accessed June 29, 2006, at http://waterdata.usgs.gov/id/nwis/qw.

Walker, F.W., Parrington, J.R., and Feiner, Frank, 1989, Nuclides and isotopes, chart of the nuclides (14th ed.): General Electric Company, Nuclear Energy Operations, $57 \mathrm{p}$.

Wegner, S.J., 1989, Selected quality assurance data for water samples collected by the U.S. Geological Survey, Idaho National Engineering Laboratory Idaho, 1980 to 1988: U.S. Geological Survey Water-Resources Investigations Report 89-4168 (DOE/ID-22085), $91 \mathrm{p}$.

Wershaw, R.L., Fishman, M.J., Grabbe, R.R., and Lowe, L.E., 1987, Methods for the determination of organic substances in water and fluvial sediments: U.S. Geological Survey Techniques of Water-Resources Investigations, book 5, chap. A3, 80 p.

Wilde, F.D., Radtke, D.B., Gibs, Jacob, and Iwatsubo, R.T., 1998, National field manual for the collection of waterquality data: U.S. Geological Survey Techniques of WaterResources Investigations Report, book 9, chaps. A1-A5 [variously paged].
Williams, L.M., 1996, Evaluation of quality assurance/quality control data collected by the U.S. Geological Survey for water-quality activities at the Idaho National Engineering Laboratory, Idaho, 1989 through 1993: U.S. Geological Survey Water-Resources Investigations Report 96-4148 (DOE/ID-22129), $116 \mathrm{p}$.

Williams, L.M., 1997, Evaluation of quality assurance/quality control data collected by the U.S. Geological Survey for water-quality activities at the Idaho National Engineering Laboratory, Idaho, 1994 through 1995: U.S. Geological Survey Water-Resources Investigations Report 97-4058 (DOE/ID-22136), 87 p.

Wood, W.W., 1976, Guidelines for collection and field analysis of ground-water samples for selected unstable constituents: U.S. Geological Survey Techniques of Water-Resources Investigations, book 1, chap. D2, 24 p. 
Publishing support provided by the U.S. Geological Survey

Publishing Network, Tacoma Publishing Service Center

For more information concerning the research in this report, contact the Director, Idaho Water Science Center

U.S. Geological Survey

230 Collins Road

Boise, Idaho 83702

http://id.water.usgs.gov 
